Portland State University

PDXScholar

7-9-1997

\title{
Teaching Phonetic-ideograph Rules to English Speaking Students of Chinese
}

Jillian Ji-fen Tsai

Portland State University

Follow this and additional works at: https://pdxscholar.library.pdx.edu/open_access_etds

Part of the Bilingual, Multilingual, and Multicultural Education Commons Let us know how access to this document benefits you.

\section{Recommended Citation}

Tsai, Jillian Ji-fen, "Teaching Phonetic-ideograph Rules to English Speaking Students of Chinese" (1997). Dissertations and Theses. Paper 5329.

https://doi.org/10.15760/etd.7202

This Thesis is brought to you for free and open access. It has been accepted for inclusion in Dissertations and Theses by an authorized administrator of PDXScholar. Please contact us if we can make this document more accessible: pdxscholar@pdx.edu. 


\section{THESIS APPROVAL}

The abstract and thesis of Jillian Ji-fen Tsai for the Master of Arts in Teaching English

to Speakers of Other Languages were presented July 9, 1997, and accepted by the thesis committee and the department.

COMMITTEE APPROVALS:

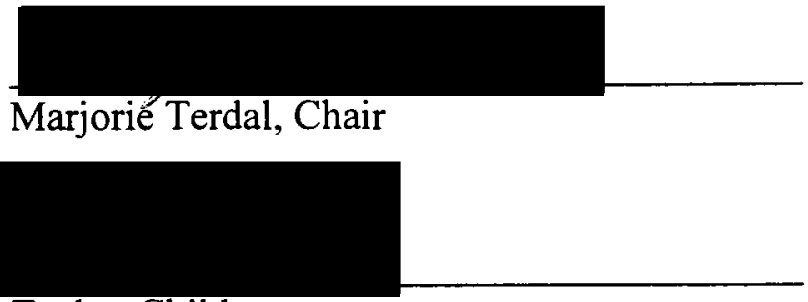

Tucker Childs

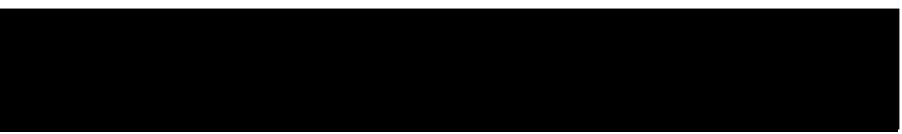

Jonathan O. Pease

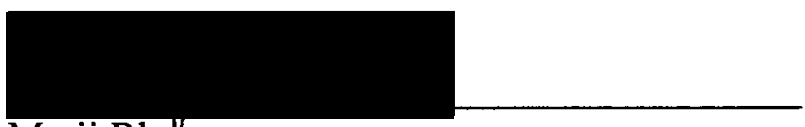

Ma-ji Rhe

Representative of the Office of Graduate Studies

DEPARTMENT APPROVAL:

Marjoríe Terdal, Chair

Department of Applied Linguistics

ACCEPTED FOR PORTLAND STATE UNIVERSITY BY THE LIBRARY

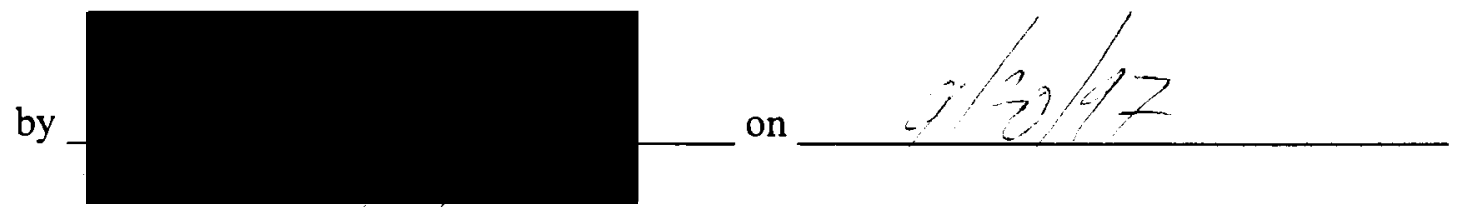




\begin{abstract}
An abstract of the thesis by Jillian Ji-fen Tsai for a Master of Arts in Teaching English to Speakers of Other Languages, presented July 9, 1997.
\end{abstract}

Title: Teaching Phonetic-ideograph Rules to English Speaking Students of Chinese.

The purpose of this study was to investigate whether the teaching of phoneticideograph rules would improve the memorization and character retention abilities of English-speaking students of Chinese.

Two groups participated in the experiment, an experimental group and a control group. The experimental group was taught using the Concentrated Character Recognition Method, which employs the teaching of phonetic-ideograph rules, while the other group was taught using a more traditional teaching approach, without receiving instruction on phonetic-ideographic rules.

Subjects were enrolled in the first-year university Chinese class. All subjects were pre-tested before the treatment. Data of subjects who scored much higher than the others on the pre-test were excluded from the analysis. The number of subjects who participated in the study was 30 . One group of native speakers of Mandarin Chinese also participated in the rare character test of the study. A short-term character recall test was held on the sixth week of the treatment. A long-term character recall test was held 
on the ninth week of the treatment. One rare-character test was given to both groups and to the group of native speakers.

The experimental group performed better than the control group on both the short-term character recall test and the long-term character recall test. Moreover, the experimental group predicted pronunciation more accurately than the control group on the rare-character test, and their performance was closer to the level of the group of native speakers than the control group. 
TEACHING PHONETIC-IDEOGRAPH RULES

TO ENGLISH SPEAKING STUDENTS OF CHINESE

by

JILLIAN JI-FEN TSAI

A thesis submitted in partial fulfillment of the

requirments for the degree of

MASTER OF ARTS

in

TEACHING ENGLISH TO SPEAKERS OF OTHER LANGUAGES

Portland State University

1997 


\section{ACKNOWLEDGMENTS}

I wish to express my appreciation to the individuals who helped me to finish my thesis. First of all, my gratitude is extended to Dr. Marjorie Terdal, my thesis advisor, who gave me many suggestions, guidance, and support in all means. I would also like to acknowledge Professor Jonathan Pease for letting me conduct my project in the university. Without his full support and vital suggestions, this project would not have been possible. My appreciation is also extended to the other members of my committee, Dr. Tucker Childs and Professor Ma-ji Rhee, for their support and interest in this study.

I am grateful for the statistical help of Victoria Neagoe and Erik Terdal, and Li Zhi Xin's professional help with the computer. I would also like to express my thanks to Eric Nacke for his insights and suggestions on the writing. Finally, I want to thank my family for all the support they have given me in earning this degree. 


\section{TABLE OF CONTENTS}

CHAPTER

PAGE

ACKNOWLEDGMENTS …....................................................... ii

LIST OF TABLES …........................................................... vi

LIST OF FIGURES

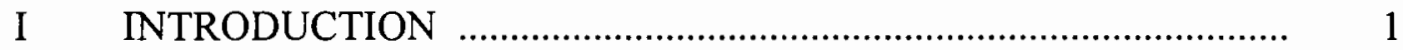

Background of the Problem .......................................................... I

Rationals and Need for the Study ................................................. 4

Hypotheses ........................................................................... 7

Definition of Terms ................................................................

II REVIEW OF THE LITERATURE ……………............................... 11

Chinese Etymology ................................................................. 12

The Six Principles of Chinese Characters ........................... 13

Phonetic-ideographs ........................................................... 18

Radicals ............................................................... 19

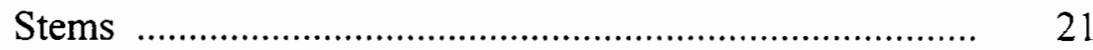

Types of Phonetic-ideographs .......................................... 23

Phonetic-ideographs with Close Phonetic Hints ......... 24

Phonetic-ideographs with Identical Phonological

Hints ............................................................... 25

Phonetic-ideographs with None-functioning

Phonological Hints ..................................................... 25

The Position of Radical and Stem .................................... 26 
Theoretical Support ……………............................................ 30

Experimental Evidence ............................................................ 33

Psycholinguistic and Cognitive Considerations .......................... 34

Direct Access Hypothesis ................................................ $\quad 36$

Phonological Recoding Hypothesis ................................... 38

Conclusion ........................................................................... 42

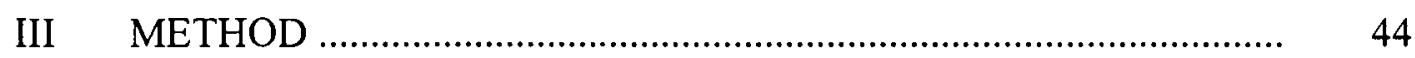

General Design of the Study .................................................... 44

Subjects ........................................................................ 45

Instruments …................................................................... 47

Material Design .......................................................................... 49

Procedures and Activities ......................................................... 50

Control Group .............................................................. $\quad 50$

Experimental Group ........................................................ 52

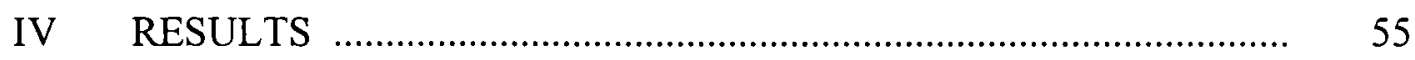

Research Hypotheses .............................................................. 55

Statistical Methods ……………………………………......... 57

Pretest ….................................................................. 57

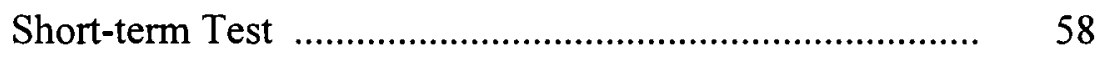

Long-term Test ............................................................. 58

Rare Character Test ..................................................... 59

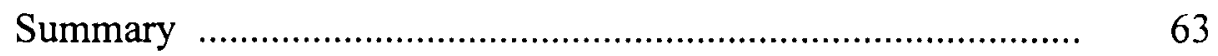

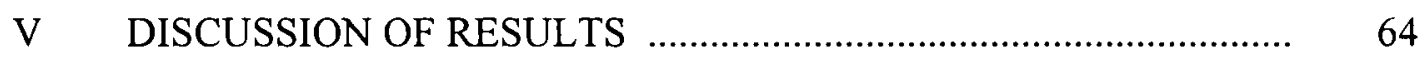

Background Problem ............................................................... 64

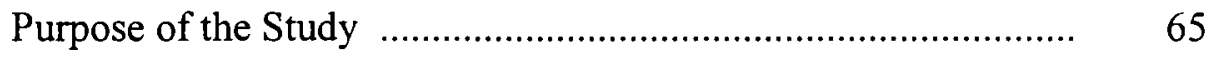




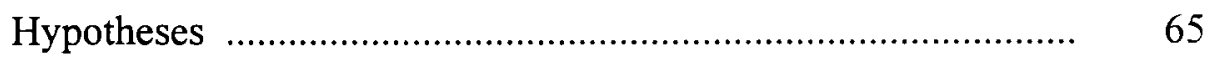

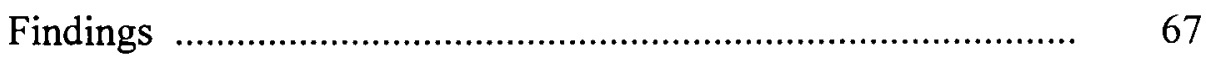

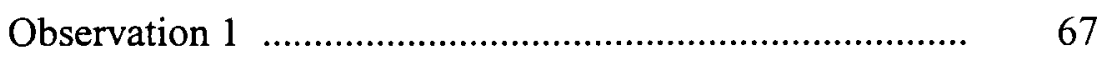

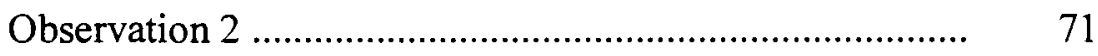

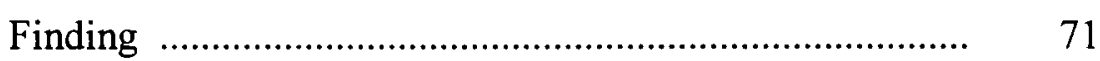

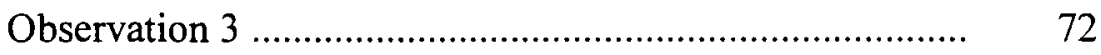

Limitations to the Study ............................................................

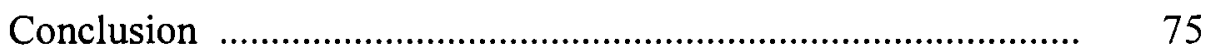

Recommendations for Further Study ........................................ $\quad 76$

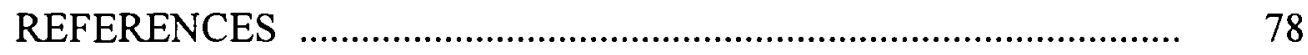

\section{APPENDICES}

A INFORMED CONSENT FORM ………………............ 83

B CHINESE CHARACTER PRETEST ………………........ 85

C THE SHORT-TERM RECALL TEST ............................... 87

D THE LONG-TERM RECALL TEST ………………......... 91

E THE RARE CHARACTER TEST ….............................. 95

F CURRICULUM (CONTROL GROUP) ........................... 97

G CURRICILUM (EXPERIMENTAL GROUP) ................. 128 


\section{LIST OF TABLES}

TABLES

PAGE

1 The Six Principles of Chinese Character

15

2 The Three Stages of Character Formation $\ldots \ldots \ldots \ldots \ldots \ldots \ldots \ldots \ldots . . . \ldots \ldots$

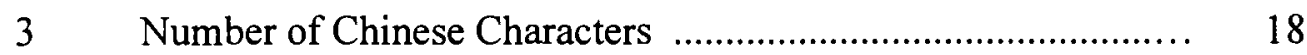

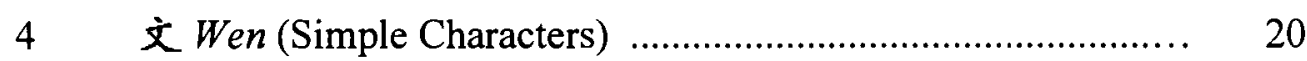

5 宇 $Z i$ (Compound Characters) ............................................ 22

$6 \quad$ Phonetic-ideographs with Close Phonetic Hints .................... 24

7 Phonetic-ideographs with Phonetic Stems Pronounced Identically to the Compound

8 Chinese Orthographic Configuration--

The Various Positions of Radicals and Stems

9 Schedule for the Control Group and the Experimental Group...

10 Age Distribution of the Control Group and the Experimental Group

11 t-test for the Pretest

12 t-test for the Short-term Character Recall Test

13 t-test for the Long-term Test ............................................ 59

14 t-test for the Rare Character Test between the Control Group and the experimental Group

15 t-test for the Rare Character Test between the Control Group and the Native Speaker Group 
16 t-test for the Rare Character Test between the Experimental Group and the Native Speaker Group

17 Responses to Individual Questions on Short-term Test ......... 69

18 Responses to Individual Questions on Long-term Test ......... 70

19 Examples of Control Group's Errors ............................. 71 


\section{LIST OF FIGURES}

FIGURES

PAGE

1 Rare Character Test Scores

61

2 Comparison of Test Scores between the Control group and the Experimental Group 


\section{CHAPTER I}

\section{INTRODUCTION}

\section{Background of the Problem}

Identifying and then producing the pronunciation of Chinese characters is a difficult task for English-speaking students of Chinese. Because present teaching methods do not teach characters according to their phonetic stems, students must struggle to learn and memorize an overwhelming number of phonetically unrelated characters. When reading a given character, students are left to rely solely on their ability to remember the pronunciation of that character without the aid of any visual clues. This results in not only a slow rate of vocabulary acquisition but also a low rate of vocabulary recall. For example, by the end of the first year, many students are frustrated by their slow rate of vocabulary acquisition and by the increasing amount of time and effort spent on remembering the growing number of characters they are learning. What is needed to solve this problem is a method that teaches students not only how to memorize characters quickly but also how to recall their pronunciation consistently. The purpose of this study is to show that the Concentrated Character Recognition Method (CCRM) for teaching Chinese characters improves the speed and efficiency of students' vocabulary acquisition while also improving their ability to recall (and guess) character pronunciation. To this end, the vocabulary acquisition rates of 
first-year students being taught by traditional character teaching methods was compared to those of students being taught by the Concentrated Character Recognition Method. Another reason English-speaking students have difficulty learning to read Chinese is found in a fundamental difference between written English and Chinese. Languages are generally grouped into two categories: logographic and alphabetic (Fromkin \& Rodman, 1988). Alphabetic languages, such as English, use combinations of letters (graphemes) to form words. The words are pronounced according to grapheme-phoneme correspondence rules (Tzeng \& Singer, 1981). This means that a word in an alphabetic language can be pronounced simply by reading a series of graphemes. Once one has memorized the various grapheme-phoneme correspondence rules of the English language, nearly any word can be pronounced even if it has not been learned or memorized.

Chinese, on the other hand, is a monosyllabic language. Each Chinese character contains one or no consonant, and a vowel. The pronunciation of a Chinese character cannot be determined merely by reading a combination of phonetic symbols ( Tzeng \& Singer, 1981). For example, the Chinese character 苦 is a combination of two

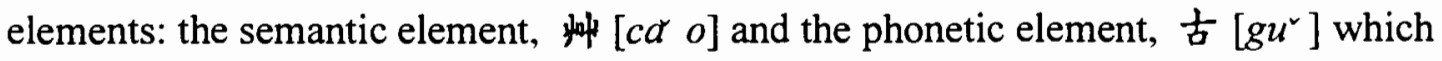
suggests the pronunciation. The element $\frac{f}{b}$ is named phonetic stem because it functions as a sound-based element which suggests the pronuncaition of the character 苦, and nothing else. The pronunciation of 苦 is not a combination of $\left[\mathrm{ca}^{\llcorner} \mathrm{o}\right]$ and

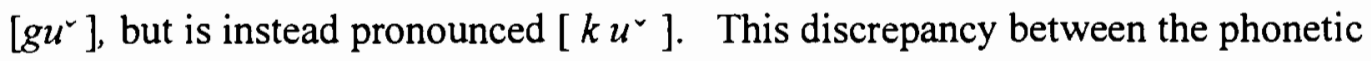


element of a character and its actual pronunciation contributes significantly to the difficulties English-speaking students experience in learning to read Chinese.

Phonetic-ideographic characters--characters that contain phonological hints-account for more than $90 \%$ of Chinese characters. Moreover, approximately $26 \%$ have a pronunciation identical to their phonetic stem. This means that the pronunciation of most characters is at least suggested by the phonetic element, while the pronunciation of others is directly related to the phonetic element. Take the character [sha] 沙, for example. 沙 is comprised of both a semantic element, 水 [shui $\left.{ }^{\sim}\right]$, and a phonetic element, 少 $\left[\right.$ shao $\left.^{2}\right]$. This phonetic element provides a hint at what the pronunciation of the character might be. In whatever character this phonetic element appears, the pronunciation will probably be either sha or cao. Therefore, the phonetic element narrows the pronunciation of the character down to two possibilities. Similarly, in English, the letter $a$ may be pronounced as $[\varepsilon, \mathrm{e}, \partial, æ]$. In order to know which pronunciation to use within different contexts one must first learn the graphemephoneme correspondence rules for the letter $a$. This is also true with Chinese characters. Students who have learned the various phonetic elements will be able to narrow down the pronunciation possibilities of a character they have not learned by applying the phonological generalizationss they have been taught.

The fundamental difference between the Concentrated Character Recognition Method and traditional teaching methods lies in the teaching of phonetic elements. It is this inclusion of phonetic stems in the teaching of Chinese vocabulary that significantly 
aids students in their ability to memorize, pronounce, and recall Chinese characters, which, in turn, increases their rate of vocabulary acquisition.

\section{Rationales and Need for the Study}

In this section the traditional teaching method will be compared with the Concentrated Character Recognition Method (CCRM) in order to illuminate the improvements CCRM could make in teaching Chinese characters. The rationale for this study will then be discussed.

The two approaches to teaching Chinese are the Fen-San Method and the Concentrated Character Recognition Method (Ye,1990). The traditional Fen-San Method introduces students to characters based on content. That is, the order in which characters are taught is based on their meaning alone, not in terms of their shape, sound, and meaning as a whole. The CCRM method, on the other hand, teaches characters in groups according to their shape, sound, and meaning. Instead of memorizing a group of characters unrelated in shape and sound, students memorize groups of characters that are related in appearance and sound. In this way it is easier for students to recognize the phonetic relationships between characters.

CCRM, as opposed to the traditional method, is an approach designed to teach characters based on the relations between characters. The following is an example of how characters are taught using the CCRM approach.

The pronunciation of the character 唞 $(d a n)$ is given to students, and the 


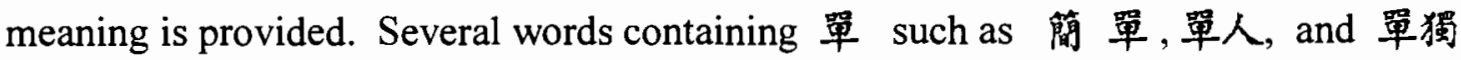
are then introduced to students. When students are familiar with the character 單, characters that contain 挐 as the phonetic stem are taught. These characters are 彈

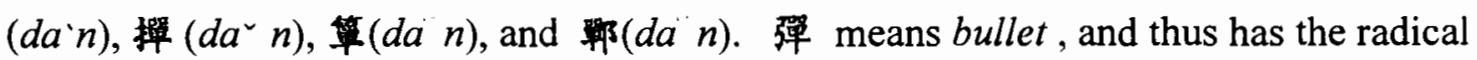
弓；嘪 means to dust, and thus has the radical 手; 龩 is a small basket, and thus has the radical. 竹; is the name of a place and, therefore, has the radical 芭. Because 彈 $\left(d a^{`} n\right)$, and 弾 $\left(d a^{`} n\right)$, characters that contain the same phonetic element, are taught along with 單 ( $\left.d a a^{\prime \prime} n\right)$, it is then easier for students to recognize the pronunciation. By learning one stem，單, many other characters can be learned all together on the basis of the phonetic relationship between the characters.

The Concentrated Character Recognition Method was first experimented with in Mainland China in 1958 (Mae, 1983). Much research was done on this method, and it showed significant success. In experiments conducted in an elementary school in Zhang-Zhou, Mainland China, first grade students taught by CCRM learned 1,345 Chinese characters in a year. Taught by the same method, second grade students in another experiment carried out in Jing-Shun elementary school learned between 2,200 and 2,500 Chinese characters (Ye, 1990). Elementary School students in Taiwan and Hong Kong who are taught using the traditional Fen-san method are said to know between 2,800 and 3,000 Chinese characters by the time they finish sixth grade ( $\mathrm{Ye}$, 1990). Second grade students taught by CCRM learned more than 2,200 characters , a 
number which approaches the 2,800 characters learned by sixth grade students who were taught by the traditional method. Students taught by CCRM obviously have a higher vocabulary acquisition rate, compared with students taught by the traditional method.

Considering how many successful cases of using the Concentrated Character Recognition Method have been reported, it seems surprising the CCRM method has not yet been adopted by more instructors of Chinese. However, it is significant to note that the students in these successful cases were learners learning Mandarin Chinese as their first language. Will this method also work for students learning Chinese as a second or foreign language? Ye (1990) suggests that there might be some problems.

First, not all Chinese characters are phonetic ideographic characters.

Secondly, many phonetic-ideographic characters, through the long orthographical change, have changed their form and thus lost any phonological hint. For example, the current character 在 $\left(z a i^{\circ}\right)$ was once written as 杜 in Small Seal Writing (Liang, 1991), with the radical \pm 'earth', and the phonetic stem 才 [cai']. The phonetic stem $才$ changed and is written as $\Varangle$, thus having lost any clue as to its pronunciation.

Finally, in order for students to understand the structure of phonetic ideographic characters, they also need to learn the 214 radicals. After they learn the radicals they can then distinguish the phonetic stem.

For the above reasons, Ye (1990) suspects that more research is needed to see 
how this method might work with students learning Chinese as a foreign language. If first language acquisition is similar to second language acquisition as Krashen indicates (1981), it would probably be reasonable to assume that this method would be as successful with second language learners as it has been with first language learners. Therefore, there is a need for a study that compares the traditional teaching method and the CCRM method in a Chinese as a Foreign Language (CFL) environment.

\author{
Hypotheses
}

\title{
Hypothesis 1
}

In the short-term test, first-year Chinese students in the experimental group exposed to the CCRM method will outperform first-year Chinese students in the control group taught by the traditional Fen-San method. For this study, performance will be measured by a character recall test.

\section{Hypothesis 2}

In the long-term test, first-year Chinese students in the experimental group exposed to the CCRM method will outperform first-year Chinese students in the control group taught by the traditional Fen-San method. For this study, performance will be measured by a character recall test. 
Hypothesis 3

In the rare-character test, first-year Chinese students in the experimental group exposed to the CCRM method will outperform first-year Chinese students in the control group taught by the traditional Fen-San method. For this study, performance will be measured by a character recognition test. 
Definition of Terms

Alphabetic A writing system in which each symbol represents one sound segment. CCRM Concentrated Character Recognition Method.

Fen-San Method A traditional content-based Chinese teaching approach.

First Language Acquisition Learning one's first language

Grapheme-phoneme Rules Sound segments that are distinctive, that contrast or distinguish words.

Logographic A word writing system in which each character represents an individual word or morpheme. For example, 餐 (meal). Longer words may be formed by combining two words or morphemes, such as 晚餐 (dinner), a combination of 晚 (evening) and 餐 (meal).

Phonetic-Ideographic Character A character that is a combination of a semantic element and a phonetic element. For example, 婚 (hu $n$ ) has a semantic element 女(woman), and a phonetic element 昏 (hu $n)$.

Phonetic-Ideographic Rules Principles by which honetic stems give hints to the pronunciation of characters. Character that follow these rules are called phonetic- ideographic characters.

Phonetic stem A phonological element that gives hints to the pronunciation. Pinyin An alphabetic writing system for Chinese utilizing the characters of the 
Roman alphabet.

Pictograph A form of writing in which the symbols resemble the real objects.

Radical A semantic element which indicates the meaning of a character.

Rare Character Characters that are rarely seen in most publication, and not commonly used in everyday life.

Second Language Acquisition Learning one's second language.

Stroke The smallest unit of a Chinese character. 


\section{CHAPTER II}

\section{REVIEW OF THE LITERATURE}

This chapter will describe the concepts involved in teaching phonetic-ideograph rules as they apply to Chinese characters. The chapter consists of five parts. The first part, "Chinese Etymology", traces the development of Chinese characters from their pictographic origins to their present, primarily phonetic-ideographic composition. The second section, "Phonetic-ideographs", discusses phonetic-ideographs in terms of their composite elements--the different types, how the phonetic elements suggest pronunciation, and the various positions of radicals and phonetic stems within characters. The third section, "Theoretical Support", considers the rationale and theory behind the use of phonetic stems in the teaching of Chinese characters. The fourth section, "Experimental Evidence", examines previous CCRM experiments performed in elementary schools in Mainland China. The fifth section, "Psycholinguistic and Cognitive Considerations", discusses some psychological aspects of how languages are learned, and examines the theory that Chinese characters are stored in our memory according to their phonological relationships. Last, I will discuss the benefits of teaching phonetic-ideographic rules to non-native Chinese speakers and the essential role they play in effective learning and retention. 
Chinese Etymology

The origin of an organized Chinese writing system dates as far back as the second millennium BC (Norman, 1988). Throughout this lengthy history the Chinese writing system has undergone innumerable changes. Of particular significance to this study is the development of phonetic-ideographs. Through time, phonetic-ideographs have continually increased to become the most common form of character in the lexicon today. This fact suggests that the number of characters containing phonetic stems which suggest the pronunciation is increasing. Phonetic-ideograph rules which teaches phonetic stems is, therefor, an essential part of Chinese character learning, and should be a significant part of character teaching methods.

In order to effectively describe the development of the phonetic-ideograph, it is necessary to begin with a look at the six principles of Chinese characters enumerated in the Shuowen Jiezi. This dictionary was the first to organize Chinese characters according to the methods by which they were formed. By looking at the Shuowen Jiezi, we can see the six fundamental types of characters at the earliest point of their differentiation. Having thus described the six basic principles, we can then compare the relative frequency of phonetic-ideographs with that of other categories of Chinese characters as they developed through history. This will reveal that the characters have developed from being largely pictographic to being predominantly phoneticideographic. 
The Six Principles of Chinese Characters: 六書 (Liu'Shi')

In Shuowen Jiezi, the first comprehensive Chinese dictionary, written in 121 $\mathrm{AD}$, characters are classified into six categories according to their composition. These categories are as follows:

1. Pictographs, 象形 [xiang xing], are drawings of real objects. According to J. Norman (1988), the growing use of writing caused the rounded lines of the primitive pictographs to become sharp angled strokes. The character 弓 'bow', for example, has changed slowly from $\xi$ ) to $\xi$, and then to $弓$, its current appearance (Downing, 1973). Most pictographs have by now lost their obvious pictorial quality.

2. Ideographs, 指事 [zhi shi], are diagrammatic characters that convey a more abstract concept: - means one, 二 means two. 上 'above', has a short horizontal line above a longer horizontal line. 下'below' has a short line below a longer horizontal line.

3. Compound ideographs, 會 意 [hui yi], are formed by putting two or more pictographs together to suggest an object or idea. One example is 林 ' forest' which is a doubling of 木, 'tree'. Many characters traditionally considered to be compound ideographs may actually be phonetic ideographs. Examples are 婚 [hūn] and 盲 [máng] whose pronunciation is suggested by the phonetic stems, 昏 [hün] and 亡 [wáng].

4. Phonetic-ideograph compounds, 形聲 [xing sheng], consist of two elements, a semantic element and a phonetic element. 河 [he'] ' river' is a compound 
of the radical 水 'water', and the phonetic element, 可 [ke ].

5. Analogous characters, 糐注 [zhuan zhu], possibly mean newer characters patterned after older characters. The new and old characters share the same meaning but do not have the same pronunciation. One example is the newer character 齐 [ye'] and the other character 父 [fu'], both of which originally meant "father" or "male elder" (Norman, 1988).*

6. Loan characters , 假 借 [jia jie], are characters which borrow their sound from pictographs or representational graphs. For example, the pictograph, 來 [la'i] 'wheat', was borrowed to represent the sound for the character 'to come' (Norman, 1988). One of the reasons for borrowing characters was to avoid creating novel graphics. Now, 來 $\left[l a^{\prime} i\right]$ has only the borrowed meaning 'to come'. The original meaning of wheat is no longer in use.

Table 1 gives additional examples of each principle.

* There is such a variety of mutually incompatible interpretations of what zhuan zhu means that it is impossible to give definitive examples. The examples provided here and in Table 1 may really be cases of phonetic ideograph construction (\# 4). 
Table 1

The Six Principles of Chinese Characters

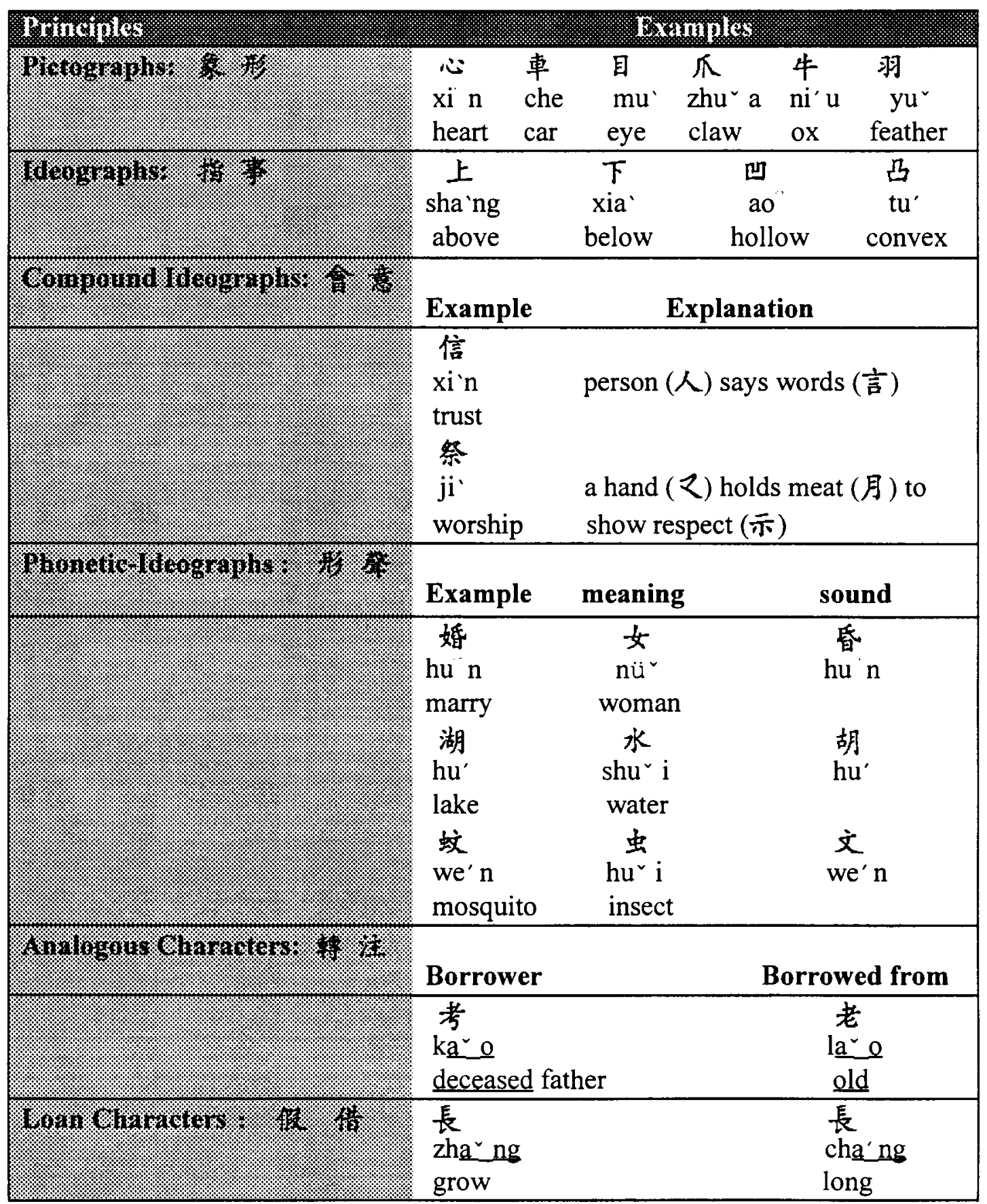


In his book, Hanzi Shihua, 漢字史話, Li Xiao Ding (cited in Ye, 1990), groups

the six principles of Chinese characters into three larger categories: characters

representing objects (pictographs), characters representing concepts (ideographs and compound ideographs), and characters representing sounds (loan characters, analogous characters, and phonetic-ideographs), as shown in Table 2. These three categories correspond to three stages of development. Li states:

中國文宇起源於圈書，圆書具借了形和意，一旦與語言相接 合，賦予圆责认語音，於是具借了形、音、義等構成文宇的 三要件，就成爲原始的象形文宇，追是表形階段；指事已屈 表意文宇，它本身是從表形遇渡到表意階段的中間產物...假 借則已進入了表音階段..形䇤宇一旦産生，不但成爲表音文 宇的主流, 也成爲所有文字的主流。

Chinese characters were initiated from picture-drawing. The pictures contained shape and meaning. Once the pictures were combined with the language, they were given a sound. The pictures then came to embody shape, sound and meaning -- the three prerequisites for language graphs--, thus becoming primitive pictographs. This was the shape-representation stage. Ideographs belong to the concept-representation category. They are a product of the transitional period between the shaperepresentation stage and the sound-representation stage...By the time loan characters had begun to develop, the soundrepresentation stage had already begun...then phoneticideographs appeared and grew to be the primary type of character not only within the sound-representation category, but also the most commonly used of all Chinese characters (Translation, p. 66). 
Table 2

The Three Stages of Character Formation

\begin{tabular}{|ll|}
\hline Characters representing objects & Pictographs \\
\hline Characters representing concepts & Ideographs \\
& Compound ideographs \\
\hline Characters representing sounds & Loan characters \\
& Phonetic-ideographs \\
& Analogous characters \\
\hline
\end{tabular}

There has been a tendency toward phonic structure throughout the evolution of Chinese characters. During the Oracle Bone period, approximately 1766-1122 BC, the majority of characters were visually based. At that time phonetic-ideographs accounted for only $27.34 \%$ of all existing characters. By 100 AD the percentage of phoneticideographs had jumped to $82.29 \%$ of the total. The number of phonetic-ideographs has continued to increase to the point where, by 1983 , they accounted for more than $90 \%$ of all Chinese characters (Qiu, 1995; Flores d'Arcais, 1992; Liang, 1991; Hoosain, 1991; Ye, 1990).

Table 3 shows that the number of phonetic-ideographs has consistently grown throughout history. Specifically, characters containing sound values have evolved from the less common type of character in the earliest stages to become the most common form of character. This clearly illustrates the tendency of Chinese characters to become increasingly phonetic in their structure. It is therefore reasonable to suggest that understanding the phonological elements is essential to effective character learning. 
Table 3

Number of Chinese Characters

\begin{tabular}{lllll}
\hline Date & writing / book & $\begin{array}{l}\text { Total } \\
\text { characters }\end{array}$ & $\begin{array}{l}\text { Phonetic- } \\
\text { ideographs }\end{array}$ & Percentage \\
\hline $1766-1122 \mathrm{BC}$ & Oracle bone writing & 2000 & 334 & $27.34 \%$ \\
$100 \mathrm{AD}$ & Shuowen Jiezi & 9353 & 7697 & $82.29 \%$ \\
$1100 \mathrm{AD}$ & Zheng Qiao & 24235 & 21810 & $90.00 \%$ \\
$1983 \mathrm{AD}$ & & 22349 & 20380 & $91.00 \%$ \\
\hline
\end{tabular}

The tendency that logographic characters are combined with other elements and function in a purely phonetic way is also found in an African logographic language, Vai script. The Vai script has a representation of the sound structure which is systematic and contains graphic symbols. Early Vai characters stand for concepts rather than sounds directly. Many of these characters have disappeared in the modern script. They are either replaced by their phonetic equivalents or combined with another element to form a different character (Scribner \& Cole, 1981). Similar to Chinese, the Vai script gradually acquired a phonetic characteristic, and transformed from a pictographic system to a phonographic system.

\section{Phonetic-ideographs}

Xu Shen states in the postface to his Shuowen Jiezi that all Chinese characters have a shape [xi'ng], a meaning [yi'], and a sound [she $n g$ ] (Norman, 1988). Phoneticideographs most clearly illustrate these characteristics. A phonetic-ideograph contains a 
radical which gives clues to the meaning, and a phonetic stem which hints at the pronunciation, and often provides the pronunciation exactly (Henshall, 1988; Cheng, 1992). For example, marry 婚 [hu n], contains the radical woman 女 [nü ], and a phonetic element 昏 [hu n]. An understanding of the radical and the stem is crucial to the understanding of phonetic-ideographs.

\section{Radicals:}

Based on his analysis of the small seal script, Xu Shen divided all characters into two broad categories, 文, wen, or simple characters, and 宇, $z i$, or compound characters (Norman, 1988). Thern (1966) defines 文,wen, and 宇, $z i$, in his English translation of the postface of the Shuowen Jiezi:

When Ts'ang Chieh first created writing ( $s h u$ 書), he probably imitated the forms according to their categories; so the figures were called "designs" 文 (wen). Later, when the writings were increased by combining the forms and phonetics, the results were called "compound graphs" 宇 $(z i)$ (p. 9).

Wen cannot be further separated into smaller components. $Z i$, on the other hand, consist of two or more components, which can be broken down into a radical and a phonetic stem. The overwhelming majority of Chinese characters belong to the $z i$ category.

Wen refer to physical objects and are non-phonetic in nature (Tzeng \& Singer, 1981). Many of them are symbols for common classes of objects such as metal, water, 
and fire (Garman,1990; Tzeng \& Singer, 1981). Wen are not only individual characters, but are also used to form zi. They are used in Shuowen Jiezi as a means of classifying 宇 $z i$, compound characters. Examples of wen are shown in Table 4.

\section{Table 4}

文 Wen (Simple Characters)

\begin{tabular}{ccccc}
\hline 金 & 年 & 水 & 火 & 土 \\
$j i i^{\circ} n$ & $m u$ & $s h u i^{2}$ & $h u^{2} o$ & $t u^{2}$ \\
metal & wood & water & fire & earth \\
\hline
\end{tabular}

When functioning as classifiers, wen are referred to as radicals. Xu Shen arranged 9,353 Chinese characters under 540 radicals (Norman, 1988). Mei Ding-Zuo, compiler of the AD 1615 dictionary titled Zihui, cut down the number of radicals to 214 (Ye, 1990; Tzeng \& Singer, 1981). One of the standard dictionaries in current use, Kangxi Zidian, uses the same set of 214 radicals to classify its 47,035 characters.

When a wen appears in a compound character (zi), it may be serving as the radical of the character. Examples are 柿, 湖, and 城. The left elements, 木, 水, and 土 function as the radicals. Radicals do not represent pronunciation, but instead hint at the character's meaning. For example, 柿 'persimmon', is a type of tree, and therefore includes the radical $木$ 'tree', as the first element.

Radicals, based on the meaning they suggest, can be divided into two types.

The first type classifies the character in a category, but does not reveal the actual 
meaning. The second type gives the meaning of the character (Liang, 1991).

Characters, 杉 'cedar' and 銅 'copper', are of the first kind. The actual meaning is not shown by the radicals. However, the radical $末$ 'tree' suggests that 杉 'cedar' is a kind of tree, and 金 'metal' suggests that 铜 'copper' is a kind of metal. This type of radical gives a clue to a wide category into which the character fits such as 'tree', 'human', or 'animal'. This type is much more common than the second type.

The second type of radical has a meaning that is very close to the meaning of the compound character. 辉 'sunshine, brightness' has the radical 光， which means 'brightness'. 艘 'strong fragrance' has the radical 香, which means ' fragrance'.

Thus, wen have the dual function of acting as individual characters and as radicals. As radicals, wen give clues to the meaning of the character of which they are a part. Radicals, themselves, are divided into two types. The first type refers to the category of meaning to which the character belongs. The second type refers more to the actual meaning of the character. A radical, however, composes only one part of a $z i$. The second part, the stem, is discussed in detail below.

Stems:

The second element of a compound character is called the stem. Like the radicals, most stems are in themselves simple characters (Huang \& Wang, 1992). For example, the stems 市, 胡, and 成 in 柿, 湖, and 城, can serve as characters independently in the following examples. 
Table5

宇 Zi (Compound Characters)

\begin{tabular}{|c|c|c|c|c|c|c|}
\hline \multicolumn{2}{|c|}{ Compound Characters } & \multicolumn{3}{|c|}{ Radical } & \multicolumn{2}{|c|}{ Stem } \\
\hline $\begin{array}{l}\text { 柿 } \\
\text { shi }\end{array}$ & $=$ & $\begin{array}{l}\text { 木 } \\
m u\end{array}$ & tree & + & $\begin{array}{l}\text { 市 } \\
s h i\end{array}$ & \\
\hline lake & $=$ & $\begin{array}{l}\text { 水 } \\
\text { shut }\end{array}$ & water & + & $\begin{array}{l}\text { 胡 } \\
h u^{\prime} \\
\end{array}$ & reckless \\
\hline $\begin{array}{l}\text { 城 city } \\
\text { che'ng }\end{array}$ & $=$ & & earth & + & $\begin{array}{l}\text { 成 } \\
\text { che'ng }\end{array}$ & to succeed \\
\hline
\end{tabular}

The primary function of the phonetic stem is to provide clues to the pronunciation of a character. However, not all stems represent the pronunciation of a character in the same way. One type of phonetic stem shares the same pronunciation as the character of which it is a part. The second type gives a more or less clear hint to the pronunciation. And the third type no longer functions as a phonetic element.

Hoosain (1991) suggests that there are 800 phonetic elements in Chinese. In Zhou He's stem handbook (1992), there are 869 phonetic stems found in 22,349 Chinese characters. Of the more than 800 phonetic stems, only 180 of these are most commonly used (Ye, 1990). These 180 phonetic stems can generate more than 5,500 characters which, according to $\mathrm{Ye}$, are quite enough to read most Chinese publications.

In order to more clearly illustrate the different types of stems, it is necessary to look at each type of stem individually and in terms of its function within the phoneticideograph. 
Types of Phonetic-Ideographic Characters:

Phonetic-ideographs are divided into three groups. The first group consists of those phonetic-ideographs whose phonetic stems give close hints to the pronunciation of the character. They comprise the majority, $90 \%$, of all phonetic-ideographs. Within the $90 \%$ of phonetic-ideographs, phonetic-ideographs containing phonetic stems pronounced identically to the phonetic-ideographs account for $26.3 \%$ (Hoosain, 1991). This will be the second group discussed. Finally, there are those characters which are categorized as phonetic-ideographs but whose phonetic stems do not reveal the pronunciation. In almost all cases, it is orthographical changes that have made the phonetic stems of these characters lose their role as pronunciation indicators. Though the exact percentage of this group is unclear, it is nonetheless quite small.

Though phonetic stems provide clues to the pronunciation of phoneticideographs, the clues are not as simplistic or direct as grapheme-phoneme rules. What phonetic-ideographic rules provide to students are possibilities for the pronunciation of a phonetic-ideograph according to its phonetic stem. Thus, a student with knowledge of radicals who encounters the character 河 will observe that the radical, 水, refers to the category of water, and will therefore gain some insight into its meaning. However, if that same student were also to have a knowledge of phonetic-ideographic rules, then he or she will observe that the phonetic stem 可 suggests two possibilities for the pronunciation of the character: $[k e]$ and $[h e]$. In this way, phonetic-ideographic rules, coupled with a knowledge of radicals, is extremely helpful to students when 
encountering a phonetic-ideograph for the first time. These phonetic-ideographic rules are discussed in more detail below.

Phonetic-ideographs With Close Phonetic Hints:

The majority of compound phonetic-ideographs include phonetic stems that hint at the pronunciation of a character ( Flores d'Arcais, 1992). Each of the stems in Table 6 indicates a close phonetic relationship to the actual pronunciation of the phoneticideograph. The pronunciation of the stem is similar to that of the character, as in the second example where the pronunciation of the phonetic stem, 主 [ $\left.l i^{`}\right]$ approximates the pronunciation of the character 垃 [le ]. According to Tsao and Wang (1983), almost $90 \%$ of all compound phonetic-ideographs are of this type.

Table 6

Phonetic-ideographs With Close Phonetic Hints

\begin{tabular}{|ccc|}
\hline Character & Radical & Stem \\
\hline $\begin{array}{c}\text { 核 } \\
\text { he } \\
\text { fruit-stone }\end{array}$ & 木 & $\begin{array}{c}\text { 亥 } \\
\boldsymbol{h a} \boldsymbol{i}^{\prime}\end{array}$ \\
\hline $\begin{array}{c}\text { 垃 } \\
\text { le } \\
\text { waste }\end{array}$ & tree & 土 \\
\hline
\end{tabular}

Because this type of phonetic stem indicates an approximate, rather than identical, pronunciation for the phonetic-ideograph, it is important for students to know all of the phonetic possibilities associated with that particular stem. For example, characters containing the phonetic stem 少 [shao], can be taught in two major groups. 
One group, 抄鈔吵炒訬，is pronounced [chao]; the other group, 沙砂紗莎少，is pronounced [sha]. Character learning and sound memorization are more systematic and more effective when these phonetic possibilities are taught to students.

Phonetic-ideographs With Identical Phonological Hints:

The first group of phonetic-ideographs contain stems whose pronunciation is identical to that of the phonetic-ideographs within which they appear (Hoosain, 1991). They account for $26.3 \%$ of all phonetic-ideographs. Examples are 才 [ $\left.\mathrm{cai}^{\prime}\right]$ in 財 [cai'], and 包 [ba'o] in 胞 [ $b a^{\prime}$ o]. This group of phonetic-ideographs have phonetic stems that can be more easily identified because the phonetic-ideographs are pronounced as they appear.

Table 7

Phonetic-ideographs with Phonetic Stems Pronounced Identically to the Compound

\begin{tabular}{|c|c|c|c|c|}
\hline Character & & Radical & & Stem \\
\hline $\begin{array}{l}\text { 財 } \\
\text { cai' } \\
\text { money } \\
\end{array}$ & $=$ & $\begin{array}{c}\text { 貝 } \\
\text { bei } \\
\text { shell }\end{array}$ & + & $\begin{array}{l}\text { オ } \\
\boldsymbol{c a}{ }^{\prime}\end{array}$ \\
\hline $\begin{array}{l}\text { 胞 } \\
\text { ba o } \\
\text { cell }\end{array}$ & $=$ & $\begin{array}{c}\text { 月 } \\
\text { ro' } u \\
\text { flesh }\end{array}$ & + & $\begin{array}{c}\text { 包 } \\
\boldsymbol{b a} \text { a }\end{array}$ \\
\hline
\end{tabular}

Phonetic-ideographs With Non-functioning Phonological Hints:

The third group of phonetic-ideographs lost their phonological function due to orthographical and phonological changes (Liang, 1991). One example is 布 [bu'] 
'cloth'. The character, 布, was written as 条. It had the radical 巾 [ii $n]$ 'towel', and its pronunciation was similar to its phonetic stem, 父 $[f u]$. However, the phonetic stem eventually changed, and the character is now written as 布 $\left[b u^{\prime}\right]$. Thus, the new phonetic stem, $\digamma$, lost its role as a pronunciation indicator (Qiu, 1995).

Another example is 成 [che 'ng]. The character, 成 [che'ng], was pronounced [di eng] before $8 \mathrm{AD}(1940, \mathrm{Ye})$. This character originally consisted of two elements, 戊 and 丁. 戊 [wu ] was the radical and 丁 [ti eng] the phonetic stem. 丁 was simplified to become $J$ in order to be combined with 戊. At that time the phonetic stem, $丁$ [ti eng], still suggested the pronunciation. However, after $8 \mathrm{AD}$ the pronunciation for 成 became [che'ng], and the phonetic stem $丁$ ceased to serve as a pronunciation indicator.

Though compound characters such as 布 $[b u$ ] and 成 [che 'ng] no longer contain perceptible phonetic stems, they are still categorized as phonetic-ideographs because their original form contained a functioning phonetic stem.

The Position of Radical and Stem:

In order to identify the possible pronunciation of a phonetic-ideograph, it is necessary to distinguish the stem from the radical. However, the radical and the phonetic stem do not appear in any standard position within a character. They can appear in a variety of locations, which contributes to the difficulty students experience 
in locating the phonetic stem. For this reason, students who learn only the phonetic stems, and receive no instruction on radicals, will have trouble telling the radical from the stem. They will mistake the radical for the phonetic stem, and thus pronounce the phonetic-ideograph according to the radical. Therefore, it is very important that students acquire knowledge of the radicals before they begin to learn phoneticideographic rules.

In the large majority of compound characters, the radicals are located on the left, and the stems are located on the right. However, this is not always the case. In contrast to most alphabetic languages where words are composed of left-to-right letters, the position of radicals and stems varies in Chinese characters (Flores d'Arcais, 1992).

Table 8 shows the various positions of radicals and phonetic stems.

$A$ stands for the radical, and $B, C, D$ stand for the stem. The horizontal $A B$ structure $A$ and the vertical $B$ structure, shown in the figure below, are the most common stemradical formations. Other configurations are " $A$ ", " $A B C$ ", " $B C$ ", and " $A$ "...etc.. (Huang \& Wang, 1992).

This lack of a single, standard position for the radical and the phonetic stem can be traced back to the early stages of character formation. Liang states:

\section{早期的形韾守，因㼳文宇㬊没有定形，結構是比较自由的，} 䧕符和音符並不固定，位置也不固定。

In this formative period there were no definitive rules governing the placement of phonetic stems and radicals. The structure was comparatively free then. For some characters, the radical and the stem could be written in a variety of positions (Translation, 1991, p.133). 
Table 8

Chinese Orthographic Configurations: The various positions of radical and stem

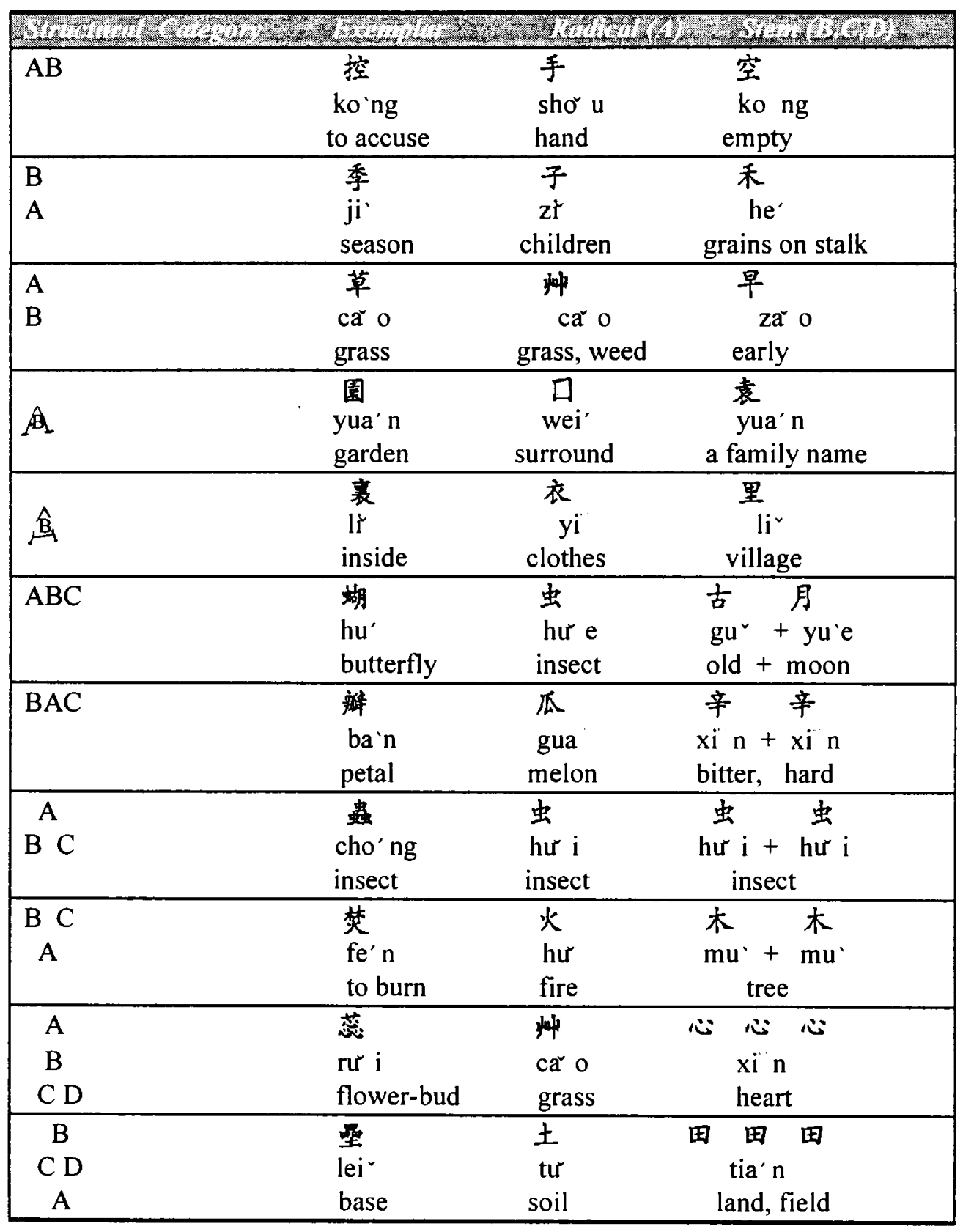


Following are three examples, 訟 [so`ng] could be written as 猂, or 坋; 祀

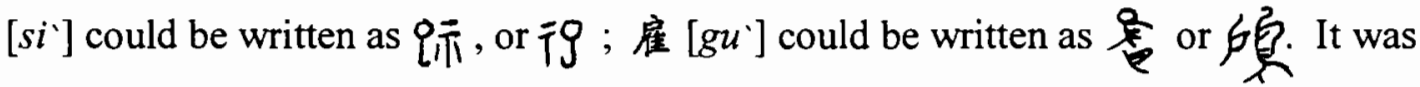
not until the Qin dynasty, approximately $200 \mathrm{BC}$, that the placement of stem and radical took on a more standard appearance (Norman, 1988). The radical and the stem were assigned a standard position within each individual character. However, this did not mean that the placement of stem and radical was the same for all characters. And it is most likely for this reason that these various locations for the radical and stem have persisted to the present.

Although there appears to be little reason to the positioning of radicals and phonetic stems, there are clues to identifying the radical. In a left-right structure, the left is usually the radical; in a top-bottom structure, the bottom is usually the radical (Liang, 1991). Generally speaking, if a character consists of a left half and a right half, the radical is commonly located on the left. For example, the radical for 理，玉, is on the left. However, as Mathews (1931) suggests there are exceptions. Certain radicals,

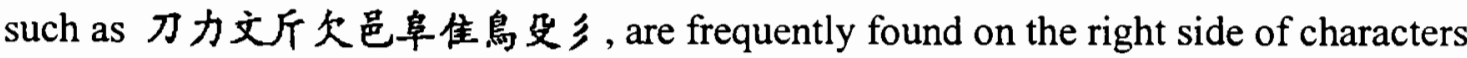
with a left-right structure.

In a character consisting of an upper half and a lower half, the lower half is usually the radical. One example for the top-bottom structure is 思 whose radical is the bottom element $心$. However, there are exceptions to this rule as well. These elements-- 恻竹穴四雨爪二放--appear in the top half of the character, though they are 
part of a top-bottom structure (Mathews, 1931).

A study by Ye De Ming (1990) examines the possible positions where radicals may occur: 104 radicals could appear in the bottom, 94 radicals on the left, 59 on the top, and 54 on the right. Most of the common radicals appear in predictable places and can be easily identified, such as the radical 灯, in 草,芬; and the radical 金, in 銅, 鐵, 銀. However, 43 radicals can appear in several places, and are therefore hard to locate. Ye (1990) states:

Among the 214 radicals, 43 of them appear at different positions according to the character in which they appear. They could be on the top, on the bottom, on the left, or on the right. One example is the various positions the radical $夕$ appears in the following characters, 外, 多, 風, 夜, 夢, 索 (Translation, p. 68).

The radical $夕$ appears in several positions in the following characters. It appears to the left of 外, inside of 夜, and on the bottom of 蒙. It is hard to be identified because of its various positions within different characters. But, regardless of radicals like $夕$, the majority of radicals appear in predictable places.

\section{Theoretical Support}

Although Chinese is often defined as a logographic language, phoneticideographs actually account for the greatest number of Chinese characters. The fact thatmore than $90 \%$ of modern Chinese characters are phonetic-ideographs implies that phonetic elements have become an essential aspect of character formation. Moreover, 
the fact that the number of phonetic-ideographs has increased through time, and continues to grow, supports the theory that there is a tendency for written Chinese to become increasingly phonetic in its structure.

While some Chinese characters still maintain their pictographic quality, many more contain phonetic stems that represent the pronunciation of the character. Although Chinese is not an alphabetic language, we cannot ignore the fact that a great majority of Chinese characters can be pronounced in a way that is similar to grapheme-phoneme rules. Many characters contain a phonetic stem whose pronunciation is identical to the pronunciation of the character of which it is a part. For instance, 閑 [lán] has a pronunciation which is identical to the character 蘭 [lán]. According to Hoosain (1991), 26.3\% of phonetic-ideograph compounds are of this type.

Within modern Chinese, the number of phonetic-ideographs continues to grow. New characters are most frequently created as phonetic-ideograph compounds, rather than as pictographs or ideographs (Hoosain, 1991). Evidence of this can be found in many recently created characters. A clear example is the character 钝 [tai $\left.{ }^{\circ}\right]$, meaning Titanium'. Its radical, 金 [ji $n]$, suggests that 鈌 [tai $]$ is a type of metal, while the phonetic stem, 太 $\left[t a i^{\circ}\right]$, represents a pronunciation that is identical to that of the character, 钝, and similar to the pronunciation of the newly-invented word 'Titanium.' Another example is 她 $[t \bar{a}]$ and 他 $[t \bar{a}]$. 她 is a newer character that obtains the use of the phonetic stem of 他, 也. This phonetic-ideograph, 她 
containing the radical of female, 女, is created to represent the female third person, she. Another trend in the development of characters toward a more phonetic structure is the modification of older characters to include new phonetic stems that more clearly suggest the phonological hint. For example, the character 證 [zhe'ng], meaning 'evidence', is an old character listed in the 121 AD dictionary, Shuowen Jiezi. 証 [zhe'ng] is a newer character invented as a substitute for 證 [zhe'ng]. This character is not contained in the Shuowen Jiezi. 證 [zhe'ng], the older form, contains the phonetic stem, 登, pronounced [de $n g$ ], which does not clearly suggest the pronunciation of the character as a whole. The new character 証 [zhe'ng], whose phonetic stem is 正 (zhe'ng), was adopted informally to provide a clearer representation of the pronunciation. 正 [zhe'ng] was then used to substitute for 登 [de $n g]$, and became the new phonetic stem. Currently, both 証 and 證 are in use. (Liang, 1991).

Given that phonetic-ideographs present phonetic stems in such an organized and systematic manner, it is not difficult to understand why they make up the largest portion of Chinese characters. They are easier to read as a result of their phonetic stems, many of which function similarly to grapheme-phoneme rules. They are frequently used to form new characters due to the fact that they can be easily created by combining a radical (semantic element) with a phonetic stem (phonetic element). According to Hoosain (1991), this eliminates the need to create novel graphics. Moreover, they can be improved upon by substituting clearer phonetic elements for those that are outdated 
or less useful. As a result of these characteristics, the number of phonetic-ideographs continue to increase. Considering that phonetic-ideographs occupy such an important position within written Chinese, an understanding of phonetic elements is an essential aspect of Chinese character instruction.

\section{Experimental Evidence}

The Concentrated Character Recognition Method (CCRM) was first used in Liaoning Province, Mainland China in 1958 as an experiment. Mae presented a report on the findings of that experiment in 1983. In his report Mae recommended the use of the CCRM as a systematic and efficient method for teaching Chinese characters. According to the CCRM, phonetic stems are taught first, then phonetic-ideographs that share the same phonetic stem are taught together in groups. In this way, characters are learned systematically in groups according to their similarities instead of individually as unrelated units. According to Mae's report, the CCRM not only quickens the learning process, but also improves character retention capabilities (Ye, 1990).

In 1983, about five to six hundred elementary schools in Mainland China were using the CCRM to teach Chinese characters. The research being carried out in these classrooms showed significant success. In a report published by the Department of Education of the People's Republic of China, first grade students in Bo-Ai elementary school in Zhangzhou City, Liaoning Province, successfully mastered 1,345 characters 
by the end of their first year.

Ye (1990) reports the achievement of another experiment carried out in Jing-

Shun Elementary School:

Second grade students learned between 2,200 and 2,500 Chinese characters by the end of their second year. Most of the students could read newspaper headlines and story books by the end of their second year in the elementary school. Results like this are highly unusual. By contrast, in previous years second grade students at Jing-Shun Elementary School had mastered only 1,200 Chinese characters by the end of their second year (Translation, p.51).

As the above examples attest, the CCRM has been found to be an effective teaching method for learners of Chinese as a first language. However, such conclusive results have yet to be found on English-speaking learners of Chinese in a CFL situation. It is the purpose of this research to test this hypothesis that the CCRM can be equally as effective a teaching method for English-speaking learners of Chinese in a CFL environment.

Psycholinguistic and Cognitive Considerations

One of the reasons the CCRM is believed to be such an efficient and systematic teaching method is the fact that characters are taught in groups related by sound and shape, thus making them easier for students to memorize and recall. The notion that teaching characters as a group according to their phonetic similarities will lead to better character retention, is based on the hypothesis of phonological recoding.

Phonological recoding hypothesis claims that phonemic recoding is necessary 
while processing language. Much research has found that characters are psychologically stored and retrieved as groups based on their phonological relationships. If it is true that characters containing the same stem are psychologically stored in groups in our memory, teaching them in phonologically related groups should best fit the mental process and presumably produce the best results in character memorization and retention.

That characters are systematically stored in our brain according to phonemes is believed to be true for both logographic languages like Chinese, and alphabetic languages like English. According to this hypothesis, teaching students phoneticideographic rules would be as beneficial to students of Chinese as grapheme-phoneme correspondence rules are to students of English.

However, some psychologists support another hypothesis, direct access, which claims that phonemic recoding does not occur during the reading process. These researchers believe that readers of logographic languages use neither the alphabetic principle nor decoding into sound in order to learn or identify words. Conversely, they suggest that phonemic recoding may be an obligatory stageonly for readers of alphabetic languages (Rozin, Poritsky, \& Sotsky, 1971).

The direct access hypothesis claims that printed words make contact with information stored in our lexicon without any speech process intervention.

The issue of the absence or presence of phonemic recoding during the reading process is still controversial. D'Arcais (cited in Chen \& Tzeng, 1992) safely finds a 
middle ground between the two. He states:

Chinese characters might completely bypass a stage of phonological encoding, and require essentially the direct, lexical route... For logographic writing (Chinese), phonological recoding is also likely to take place... In both English and Chinese high frequency words would be read 'logographically' via the direct route, while low frequency words would be read 'analytically' via a phonological route. In conclusion, the available evidence does not seem to indicate dramatic processing differences for words written in alphabetic or in logographic orthographies.

(p. 48,49)

The following is a detailed discussion of the two major hypotheses, presenting the rationales and empirical evidence for both the direct access hypothesis and the phonological recoding hypothesis.

Direct Access Hypothesis:

The direct access hypothesis asserts that readers are able to go directly from the printed word to the lexical representation in their mental dictionary. Many researchers who favor the direct access hypothesis argue that Chinese orthography relates directly to meaning, whereas English orthography relates words to meaning through a phonetic system. Therefore, the reading of an alphabetic language may involve different processes than the reading of a non-alphabetic language (Liu, cited in Feitelson 1976; Rozin, Poritsky, \& Sotsky, 1971).

Chinese characters have also been treated in several psychological experiments as nonrepresentational stimuli for English-speaking people because they lack verbally 
defined components, such as phonemes. Rozin, Poritsky, and Sotsky (1971) claim:

What is the critical feature between the Chinese logographic and the English alphabetic system which leads to reading difficulty? It could be the complete absence of sound mapping in Chinese ... because Chinese characters map into language at the morphemic (word) level rather than at the phonemic level. (p. 113)

In a study of Philadelphia second-grade school children with serious reading problems, Rozin, Poritsky, and Sotsky reported that the children were able to make rapid progress in learning and reading Chinese. They suggested that their success was due to the fact that reading the logographic Chinese characters did not require the speech recoding level.

Many empirical findings in Japan support the hypothesis that reading alphabetic and logographic writings may entail different processes. A study in Japanese aphasic patients by Sasanuma (1974) found evidence of phonological recoding for alphabetic $k a n a$ and direct acess for the logographic kanji.

The direct access hypothesis asserts that reading processes for logographic Chinese and alphabetic English are different. Evidence supports the hypothesis that Chinese orthography relates directly to meaning, and therefore the phonological recoding is not a necessary stage.

The following is a discussion of another hypothesis, the phonological recoding hypothesis, which holds a different view concerning the processes of reading an alphabetic language and a non-alphabetic language. 
Phonological Recoding Hypothesis:

Researchers who believe that phonemic recoding does occur in working memory object to the suggestion that the critical difference between logographic and alphabetic writing lies in the step of phonemic recoding during reading. Tzeng, Hung, and Wang (1977) point out some weaknesses in Rozin's study of the second-graders with reading difficulties. They claim that the novelty of Chinese characters may have increased the subjects' motivation, and that their reading difficulties may have been the result of poor teaching methods. They, therefore, question the reliability of the results in Rozin's study as well as the claim that Chinese does not require phonological recoding during the reading process.

An experiment conducted by Yin and Butterworth (1992) produced evidence that the decoding processes for Chinese and alphabetic writing systems are the same. In their experiment, eleven brain-damaged Chinese patients with reading disorders were asked to read aloud 87 Chinese characters, including 40 common regular characters, 21 common irregular characters, 12 common phonetic-ideographs, and 14 invented pictophonetic (two-component) characters. The errors of the subjects were categorized into two types: regularization and semantic errors. Subjects who pronounced 秤 [cheng] as [ping], committed errors classified as regularization. This type of error is a result of mistaking the pronunciation of the phonetic stem. In this case, the subjects have mispronounced 秤 [cheng] for 評 [ping] because both share the same phonetic stem, 平 [ping], yet have a different pronunciation. Subjects who pronounced 秤 
[cheng] as 苗 [miao] "young grain", committed errors classified as semantic errors. The mispronunciation of 秆 [cheng] as 苗 [miao] was considered a semantic error because the two characters are semantically related. 棌 [cheng] has the radical 禾 which means grain, while 苗 [miao] has the actual meaning of young grain. Thus, the subjects pronounced the character 秤 [cheng] according to the meaning of its radical, thereby committing a semantic error.

This study supports the concept that phonological decoing is necessary during the reading process in two ways. First, the surface dyslexia patients made a high proportion of regularization errors. Second, the semantic errors made by these patients were only on characters which did not have a phonetic stem in their construction. It, therefore, seems that the presence of a phonetic stem reduced the semantic errors. Studies of normal subjects generally show similarities in the processing of different writings. The following evidence suggests that written characters are perceived and stored in terms of systematic phonemes.

An experiment conducted by Yin (cited in Yin \& Butterworth, 1991) studied normal subjects who were asked to pronounce many different types of characters. The presence of a phonetic stem was found to suppress a semantic error.

Tzeng, Hung, and Wang (1977) conducted two experiments to find evidence of phonemic effects in reading logographic characters. They analyzed the subjects' errors and made the following conclusion: 
Analysis of the kinds of errors the subjects make suggests that this storage is phonetically organized ... in fact, the data suggest similarity rather than differences, between visual processing of Chinese characters and of English words in working memory. As the results of this experiment show, both processes involve phonetic recodings of visually presented symbols. (p. 626)

The results suggest a similarity between the reading processes of Chinese characters and English words in working memory. They also support the theory that the phonetic recoding of printed words is necessary for the processing of Chinese as well as English. Moreover, the errors committed by the subjects in the above studies were more often due to phonological similarities than to visual or semantic similarities. Because similar sounding words are clustered together in our brain, the attempt to retrieve one word may also activate its phonological neighbors (Hirsh-Pasek, Reeves, \& Golinkoff, cited in Gleason \& Ratner 1993). Due to this phenomenon, errors made by the subjects in the study were very possibly caused by these phonetic similarities. This finding further suggests that characters are stored in our brain based on their phonological relatedness.

The phenomenon that phonological neighbors are activated when one character is perceived suggests a phonemic effect in the processing of Chinese. Supposing this to be true, we may then suggest that when a Chinese character is perceived, the phonetic stem immediately activates a group of similar sounding characters containing that same phonetic stem. For example, when the character 笙 is perceived, a group of characters in our memory, 星性姓胜, pronounced [xing], and 牲侽铑趾, pronounced 
[sheng], are immediately activated. These clusters of characters appear because they all contain the same phonetic stem and are pronounced similarly. The reader then decides whether $[x i n g]$ or $[$ sheng $]$ is the proper pronunciation. It is highly improbable that the reader would mispronounce 箨 $[$ sheng] 'musical instrument consisting of a number of pipes' as [ $y u$ ] 等 'musical instrument consisting of 36 reed pipes' as a result of their similar meanings. Nor would the reader mispronounce 笙 as 管 $[$ guan] 'pipe', based on the radical they share. Therefore, we can say that characters are not stored in groups based on semantic meaning or shape (radical), but rather on the pronunciation represented by the phonetic stem. If characters are grouped psychologically on the basis of their phonological relationship, learning them according to groups of phonetic stems should best fit the natural psychological process.

Empirical evidence suggests that even the visual processing of Chinese characters involves phonetic recoding in short-term retention. Some researchers believe a phonetic code is the preferred form of representation in reading behavior across languages and across writing systems (Tzeng, Hung, Wang, 1977; d'Arcais, 1992; Cheng, 1992). If this is the case, teaching students phonetic-ideographic rules would be as beneficial to students of Chinese as grapheme-phoneme correspondence rules are to students of English. 
Conclusion

A knowledge of phonetic-ideograph rules is essential to character learning because these rules can be used to anticipate the pronunciation of the vast majority of Chinese characters. The teaching of characters containing the same phonetic stem as a group is said to fit the psychological process of character perception, because it is believed by psycholinguists that characters are stored and retrieved based on their phonological relatedness. Based on this theory, experiments were conducted at elementary schools in Mainland China where the success of teaching phoneticideographic rules to native speakers of Mandarin Chinese proved to be highly effective. This was a result of teaching familiar sounding characters in groups based on the phonetic stem they share.

Experiments carried out on first language learners of Chinese, and furthermore in research on the psychological processing procedure of Chinese characters, suggest a similarity between the processing of written Chinese and written English (e.g. Cheng 1992; Yin \& Butterworth, 1992; Tzeng, Hung, Wang, 1977). Chen states

Reading Chinese characters requires phonological mediation. The mechanism underlying this phonological mediation is thought to be based on character-sound correspondences which are well developed through years of extensive practice. Such phonological transformation is free from orthography and should equally apply to all writing systems. (1992, p. 89)

This suggests that phonetic-ideograph rules should be as beneficial to learners of Chinese as a second language, as are grapheme-phoneme rules to learners of English. 
Although the previous discussion has stated the difference between the logographic language, Chinese, and the alphabetic language, English, the difference lies only on the surface. To paraphrase Greenberg (1966), the differences between languages are like the one-twelfth of an iceberg above the surface of the water, highly visible but not significant. It is the eleven-twelfths of the linguistic iceberg wherein lies the common potential for all languages.

Supported by the above rationales, the investigator is of the opinion that teaching phonetic-ideograph rules to English speaking students of Chinese is beneficial for efficient character learning, and long lasting character retention. 


\section{CHAPTER III}

\section{METHOD}

This project was designed as an experimental study involving three classes of university students divided into two groups, a control group and an experimental group. The control group learned Chinese characters taught according to the traditional Fen San method, while the experimental group learned Chinese characters according to the CCRM method.

\section{General Design of the Study}

This study was carried out in three first-year, first-term Chinese classes at a university in the Northwest. The class met five hours a week for eleven weeks. The Chinese character instruction did not begin until the third week of the term. The treatment lasted for nine weeks, starting in the third week of the term and ending in the eleventh week. See Table 9 .

Each week, students in both groups spent four hours studying the text, grammar, quizzes, and conversational dialogues, while one hour was spent on Chinese character instruction. Two instructors taught the classes. The investigator taught the Chinese character lessons, while the text and grammar were taught by the other instructor. Students were informed at the beginning of the course to direct all questions regarding 
characters to the investigator so that the instruction of phonetic-ideograph rules would be consistent.

Table. 9

Schedule for the Control Group and the Experimental Group

\begin{tabular}{clll}
\hline Class & \multicolumn{2}{c}{ Teaching Material } & Packet / Tests \\
& Control & Experimental & Pretest \\
\hline 1st Week & & & Radical List \\
2nd Week & & Radicals & \\
3rd Week & Radicals & Radicals & Radicals \\
4th Week & Radicals & Radicals + Phonetic Stems & Character Packet \\
5th Week & Radicals & Radicals + Phonetic Stems & \\
6th Week & Radicals & Radicals + Phonetic Stems & \\
7th Week & Radicals & Radic & \\
8th Week & Radicals & Radicals + Phonetic Stems & Short Term Test \\
9th Week & Radicals & Radicals + Phonetic Stems & \\
10th Week & Radicals & Radicals + Phonetic Stems & \\
11th Week & Radicals & Radicals + Phonetic Stems & Long Term Test \\
12th Week & & & Rare Character Test \\
\hline
\end{tabular}

\section{Subjects}

The project conducted by the investigator took place during the Fall term firstyear Chinese course when students had just entered the Chinese program. One class was assigned to the control group and the other two classes comprised the experimental group. There were originally 16 students in the control group and 23 students in the experimental group. After the pretest, 13 students remained in the control group and 17 
students remained in the experimental group. See Table 10 for a display of the age distribution of the two groups..

Table. 10

Age Distribution of the Control Group and the Experimental Group

\begin{tabular}{ccccc}
\hline Age & $\begin{array}{c}\text { Control } \\
\text { Group Male }\end{array}$ & $\begin{array}{c}\text { Control } \\
\text { GroupFemale }\end{array}$ & $\begin{array}{c}\text { Experimental } \\
\text { Group Male }\end{array}$ & $\begin{array}{c}\text { Experimental } \\
\text { Group Female }\end{array}$ \\
\hline $10-15$ & 2 & & 3 & 3 \\
$16-20$ & 1 & 4 & 2 & 6 \\
$21-30$ & 4 & & 1 & 1 \\
$31-40$ & 1 & 1 & & 1 \\
$41-50$ & & 5 & 6 & 11 \\
$51-60$ & & & & \\
Total & 8 & & & \\
\hline
\end{tabular}

On the first day of class, students were informed that the research would be conducted throughout the term. They were also told that they would be taking part in a research project examining how English speaking students learn Chinese characters, and that there would be a "test". The investigator clearly stated to the students that their performance in this project and their scores on the evaluations would not affect their grade in the Chinese class.

Moreover, all students were told that they would not be allowed to switch between classes or attend class in a different session even though they might wish to do so. This policy was set in order to prevent control group students from receiving CCRM instruction. Students understood that this rule was to ensure the fair and accurate performance of the research. 
Finally, students were told that they were free to choose whether or not they wanted to participate in this research. If they chose not to take part, then their scores on the research tests would not be included in the data. Students were not aware of a control group or an experimental group, nor were they informed of any differences in teaching methods between the three classes.

This study was reviewed and approved by the Human Subjects Research Review Committee. Students also signed a consent form (see Appendix A).

\section{Instruments}

Before the treatment was conducted, the students were administered a pretest to determine how much the students already knew regarding the pronunciation of some basic Chinese characters. The pretest (see Appendix B) consisted of thirty Chinese characters chosen from the students' textbook, Elementary Chinese Reader I. Each student met with the investigator individually, and was asked to pronounce each character orally.

In the sixth week of the treatment a short term test was held. Two weeks later a long term test was given. The rare character test was held in the last week of the term, in conjunction with the students' final exam for the class. (See Table 9 for a clear display of the test schedule). The format for both the short term and the long term tests were the same (see Appendix C \& D). For both tests, students were asked to write down the pronunciation of thirty characters in Pinyin. For each character, four possible English 
definitions were provided, only of one which was correct. Students were asked to choose one. The investigator's main focus in administering the short-term and longterm tests was to measure the students' pronunciation recall ability. However, data related to the students' meaning recall performance were also collected. The following is a sample question:

\section{1. 妄 wang}
a. a female dancer
b. death
c. false, reckless
d. to marry

In the rare character test (see Appendix E), students were asked to write down the pronunciation of the thirty Chinese characters, none of which had yet beenintroduced to the students. The characters were carefully chosen based on their uncommon nature. None of them are commonly seen in most publications and dictionaries, nor are they ordinarily used by most Mandarin-speaking people.

The rare character test was given to both the experimental group and the control group, as well as a group of eighteen native Mandarin speakers who volunteered to take part in this experiment. The performance of the native Mandarin speakers was compared with that of the control group and the experimental group. These eighteen native speakers, one mainland Chinese and seventeen Taiwanese, were overseas students studying at the same university where the study was conducted. 
Material Design

Both the control group and the experimental group were given instruction beginning with radicals. The major difference in the materials between the two groups was that the experimental group received instruction in phonetic-ideograph rules, while the control group did not. All the materials were written using traditional characters.

In the beginning of the treatment, each student in both the control and experimental groups received a character packet. Character packets for both groups contained the same characters, but were organized differently. Character packets given to the students in the control group organized characters into groups according to their radical. For example, 妈, 姑, and 媳, all contain the same radical, 女, and would therefore be introduced to students at the same time. (See Appendix F for lessons). Character packets for the experimental group, on the other hand, were designed to group together those characters which share the same phonetic stem. Characters, 鯉, 理, and 俚, all contain the same phonetic stem 里, and would be taught as a group. (See appendix $\mathrm{G}$ for lessons). All the Chinese characters in both packets contained Pinyin romanization as well as the definition in English.

The control group character packet included a total of 557 Chinese characters grouped under 95 commonly used radicals. In the packet given to the experimental group, a total of 629 characters were listed under 93 phonetic stems. Among the 629 characters, 557 characters overlapped with those in the control group packet. More characters were included in the experimental group packet because the investigator 
wanted to provide students with more examples of phonetic-ideograph rules. However, none of these extra 72 characters were used in any of the short term, long term, or rare character tests.

\section{Procedures and Activities}

Both groups received character instruction for 20 to 30 minutes twice a week. The character learning packet began with instruction about radicals. The instructor first introduced 40 of the most commonly used radicals. It was explained that a radical serves as an indicator to the meaning of the character. Instruction in radicals lasted for two weeks, after which time students received a character packet. It was from this point that the teaching methods for the two groups began to diverge. The respective teaching procedures were conducted as follows.

\section{Control Group:}

In the control group, the investigator wrote the five radicals, 人日山心心， on the blackboard. The pronunciation and the meaning of these five radicals were reviewed. The investigator then said the English definition of a character selected from the packet. Students would then identify what radical the character contained without looking at the packet. After students identified the radical, they were asked to look at the character packet to find the character under that radical and pronounce it out loud. This activity continued until students could respond quickly and accurately. Finally, 
students were asked to repeat after the investigator the pronunciation of each character in the lesson.

In each class, the investigator would review the radicals and characters before teaching new radicals and new characters. The most common activity used in class was the radical-matching game. Every student received several cards with a character and its pronunciation written on each. Students first decided which radical the character contained, then they circulated around the classroom looking for the student with another character containing the same radical. After two students agreed that their two characters posses the same radical, they would put their two cards on the blackboard together and write the radical above them on the board. After all the cards were paired and put on the board, students were asked to pronounce their characters to the class.

Another activity used for character review divided students into pairs, with each pair of students receiving a piece of paper with ten or more characters written on it. The ten characters were written on the paper in a random fashion, with each character having at least one other character containing the same radical. Students would then group the characters according to their radicals, and write pinyin and the English meaning next to each character on the paper. Students were allowed to look at their character packet if necessary. Later, each pair of students would present how they grouped the characters and would pronounce each character to the class. 
Experimental Group:

After the first two weeks of instruction in radicals, students in the experimental group were able to recognize the radical in a Chinese character. In the first lesson of phonetic-ideograph rules, the investigator wrote five phonetic stems $\dot{\tau}$ ，馬，艮，五， 吾, and 子 (included in lesson E-5 of the character packet) on the blackboard. The pronunciation of the five phonetic stems was also introduced. The investigator would then point at these phonetic stems randomly and ask students to give the pronunciation. This exercise continued until students had become familiar with the phonetic stems. The different pronunciation possibilities suggested by each of these five phonetic stems were then introduced. Students learned, for example as they saw a character containing the phonetic stem 馬, that the possible pronunciation for this stem would be ma. Likewise, if the stem $亡$ appeared in a character, the possible pronunciation for this would be wang or mang. Then the investigator would pronounce a character selected from the packet. Students would then identify what phonetic stem the character contained without looking at the packet. After students had identified the phonetic stem, the investigator would say the English definition of that character, and the students would then look for that character in the packet and pronounce it out loud. This activity continued until students could quickly find characters.

The investigator would review previously taught phonetic stems and characters before teaching new ones. The most common review activity was the stem-matching game. Every student received several cards with a character written on each. Students 
would first decide which phonetic stem the character contained, then they would circulate around the classroom and find the student who had another character that contained the same phonetic stem. After the two students agreed that their two characters contain the same phonetic stem, they would put the two cards on the blackboard together and write the phonetic stem above them on the board. After all the cards were paired up and put on the board, students would pronounce the characters that were grouped together and identify the phonetic stem in each pair.

Another activity used to review characters would divide students into pairs with each pair of students receiving a piece of paper with ten or more characters written on it. The ten characters were written on the paper in a random fashion with each character having at least one other character containing the same phonetic stem. Students would then group the characters according to their stems, and write the pinyin and the English meaning next to each character on the paper. Students were allowed to look at their character packet if necessary. Later, each pair of students would present how they grouped the characters and would pronounce each character to the class.

The time spent on Chinese character instruction in both groups was the same. However, the experimental group did not spend as much time on pronunciation practice as the control group. In the control group, the investigator would go through each Chinese character and practice its pronunciation without reference to the pronunciation of other characters with the same phonetic stem. In the experimental group, only some characters from the packet were drawn to illustrate the functioning of the phonetic 
stems.

If the experimental group performed better than the control group, and the hypotheses were supported by the results, then the investigator could claim that a positive influence was gained from the instruction of phonetic-ideograph rules. 


\section{CHAPTER IV}

\section{RESULTS}

In this chapter, the statistical test used for analyzing the data collected was that of the t-test. The t-test was used to compare the mean difference between the two groups.

The t-test utilizes the ' $\mathrm{t}$ ' value and the probability level, $p$ value. The probability level used for rejecting the hypotheses is .05 (5 out of 100). If ' $p$ ' is .05 or less, then the hypothesis is not rejected. If ' $p$ ' is greater than .05 , then the hypothesis is rejected.

\section{Research Hypotheses}

This study was designed as a comparison of two different Chinese character teaching methods, the traditional Fen-San method and the Concentrated Character Recognition Method (CCRM). Research was conducted on a control group and an experimental group in terms of their performance under the two different treatments. The control group received Chinese character instruction according to the traditional Fen-San teaching approach, while the experimental group was taught according to the CCRM. The Fen-San method teaches Chinese characters on the basis of their radical. That is, characters which share the same radical are taught as a group. The CCRM, on the other hand, groups characters according to phonetic stem. Although the teaching 
of radicals is still an important part of the instruction, it is not the organizational basis. Instead, characters are organized and introduced in phonetically related groups.

The research hypotheses are as follows:

\section{Hypothesis1}

First-year Chinese students in the experimental group exposed to the CCRM method will recall more Chinese characters on the short-term recall test than will the first-year Chinese students in the control group taught by the traditional Fen-San method. The short-term recall test will be held in the sixth week of the treatment.

\section{Hypothesis 2}

First-year Chinese students in the experimental group exposed to the CCRM method will recall more Chinese characters on the long-term recall test than will the first-year Chinese students in the control group taught by the traditional Fen-San method. The long-term recall test will be held in the ninth week of the treatment.

\section{Hypothesis 3}

The performance of the first-year Chinese students in the experimental group exposed to the CCRM method will more closely approximate the performance of the group of native Mandarin speakers on the rare-character test than will the first-year Chinese students in the control group taught by the traditional Fen-San method. The rare-character test will be held in the ninth week of the treatment. 
Statistical Methods

Pretest:

All students were asked to participate in the pretest in order for the researcher to determine the students' level of Chinese character knowledge. Students were tested on their ability to identify the pronunciation of 30 Chinese characters.

The control group originally consisted of 16 students, while the experimental group consisted of 26 students. After excluding students who scored too high on the pretest, and those students who were unable to participate throughout the research, 13 students remained in the control group and 17 students remained in the experimental group.

Table 11 shows the results of the pretest. Based on the significance level $(p=$ .287 ) in the t-test for equality of means, we do not reject the hypothesis that the two population means are equal. The analysis supports the equality of the two groups prior to the treatment.

\section{TABLE 11}

t-test for the Pretest

\begin{tabular}{lcccc}
\hline Variable & Case & Mean & Standard Deviation & SE of Mean \\
\hline Control Group & 13 & 1.23 & 1.6 & .444 \\
Experimental Group & 17 & 2.47 & 4.3 & 1.043 \\
\hline
\end{tabular}

$(p=.287>.05)$ 
Short-term Test:

Students were tested on their ability to identify the pronunciation of 30 characters, with a score of 5 points per character. The total number of points possible was 150 . Table 12 shows the short-term test scores for the experimental and control groups.

TABLE 12

t-test for the Short-Term Character Recall Test

\begin{tabular}{lcccc}
\hline Group & Count & Mean & Standard Deviation & SE of Mean \\
\hline Control Group & 13 & 27.4615 & 30.063 & 8.338 \\
Experimental Group & 17 & 65.8824 & 30.327 & 7.355 \\
\hline
\end{tabular}

$(p=.002<.05)$ Scores are not percentages.

The test of the mean difference produced statistically significant group differences $(p=.002)$. According to the mean difference between the two teaching method results, hypothesis 1 is supported. There was a statistically significant difference between the experimental group and the control group.

Long-term Test:

The long-term test also measured students ability to recall the pronunciation of 30 characters, with a score of 5 points per character. The total number of points possible was 150 . The following table shows the long-term test scores for both the experimental group and the control group. 
Table 13

t-test for the Long-Term Character Recall Test

\begin{tabular}{lllcc}
\hline Group & Count & Mean & Standard Deviation & SE of Mean \\
\hline Contrcl Group & 13 & 20.9231 & 23.988 & 6.653 \\
Experimental Group & 17 & 71.7059 & 37.550 & 9.107 \\
\hline$(\mathrm{p}=.000<.05)$ & & & &
\end{tabular}

The t-test of the mean difference produced statistically significant group differences between the two teaching methods employed. There was also a statistically significant difference between the average scores of the two groups $(p=.000)$. Considering the mean difference between the groups, hypothesis 2 is supported.

Rare Character Test:

The rare-character test measured students' ability to identify the pronunciation of 30 characters with which they were entirely unfamiliar, and compared their ability with 18 native Mandarin speakers. The total number of possible points was 150 . The following tables show the rare character test scores for the control group, the experimental group, and the group of native Mandarin speakers.

TABLE 14

t-test for the Rare Character Test between the Control Group and the Experimental Group

\begin{tabular}{lllcc}
\hline Group & Count & Mean & Standard Deviation & SE of Mean \\
\hline Control Group & 12 & 28.5000 & 21.740 & 6.276 \\
Experimental Group & 17 & 57.4118 & 21.069 & 5.110 \\
\hline$(\mathrm{p}=.001<.05)$ & & & &
\end{tabular}


TABLE 15

t-test for the Rare Character Test between the Control Group and the Native Speaker Group

\begin{tabular}{lllcc}
\hline Group & Count & Mean & Standard Deviation & SE of Mean \\
\hline Control Group & 12 & 28.5000 & 21.740 & 6.276 \\
Native Speaker Group 18 & 83.1667 & 12.922 & 3.046 \\
\hline$(p=.000<.05)$ & & & &
\end{tabular}

\section{TABLE 16}

t-test for the Rare Character Test between

the Experimental Group and the Native Speaker Group

\begin{tabular}{lllcc}
\hline Group & Count & Mean & Standard Deviation & SE of Mean \\
\hline Experimental group & 17 & 57.4118 & 21.069 & 5.110 \\
Native Speaker Group 18 & 83.1667 & 12.922 & 3.046 \\
\hline$(\mathrm{p}=.000<.05)$ & & & &
\end{tabular}

Results of the mean difference in Table 14 indicate a statistically significant difference between the control group and the experimental group for the teaching methods employed $(p=.001<.05)$. The results show that the experimental group identified the pronunciation of rarely seen Chinese characters more accurately than the control group.

The mean difference between the control group and the native speaker group in Table 15 is greater than the mean difference between the experimental group and the native speaker group in Table 16. This would indicate that students who received instruction on phonetic-ideographic rules performed more closely to the level of the 
native Mandarin speakers than students in the control group. Hypothesis 3 is, therefore, supported.

Figure 1 shows a comparison of the three groups' test scores on the rare character test.

Figure 1

Rare Character Test Scores

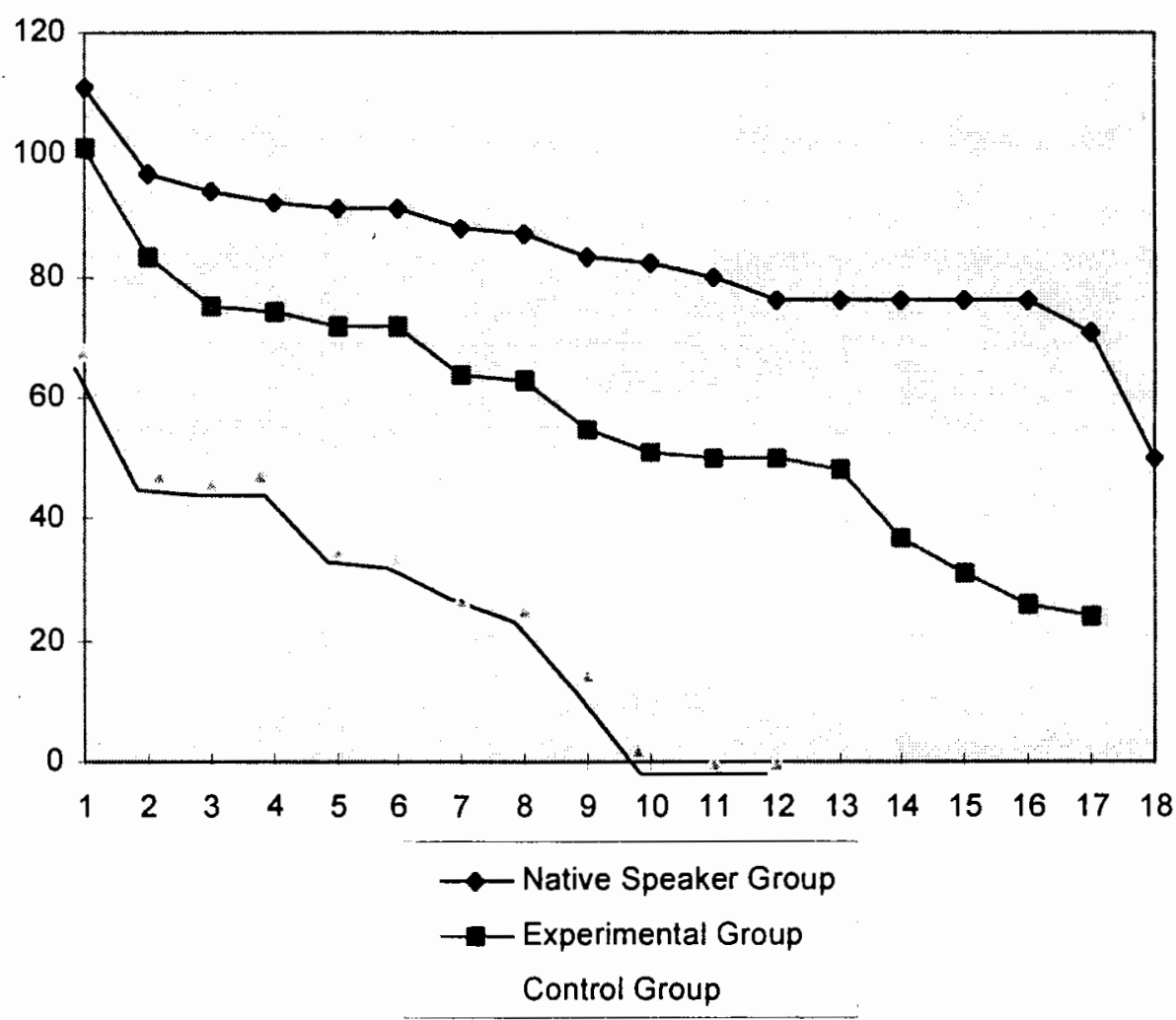


Figure 2 is a comparison of the average scores on the short-term test, the longterm test, and the rare character test between the control group and the experimental group.

Figure 2

Comparison of Test Scores between the Control Group and the Experimental Group

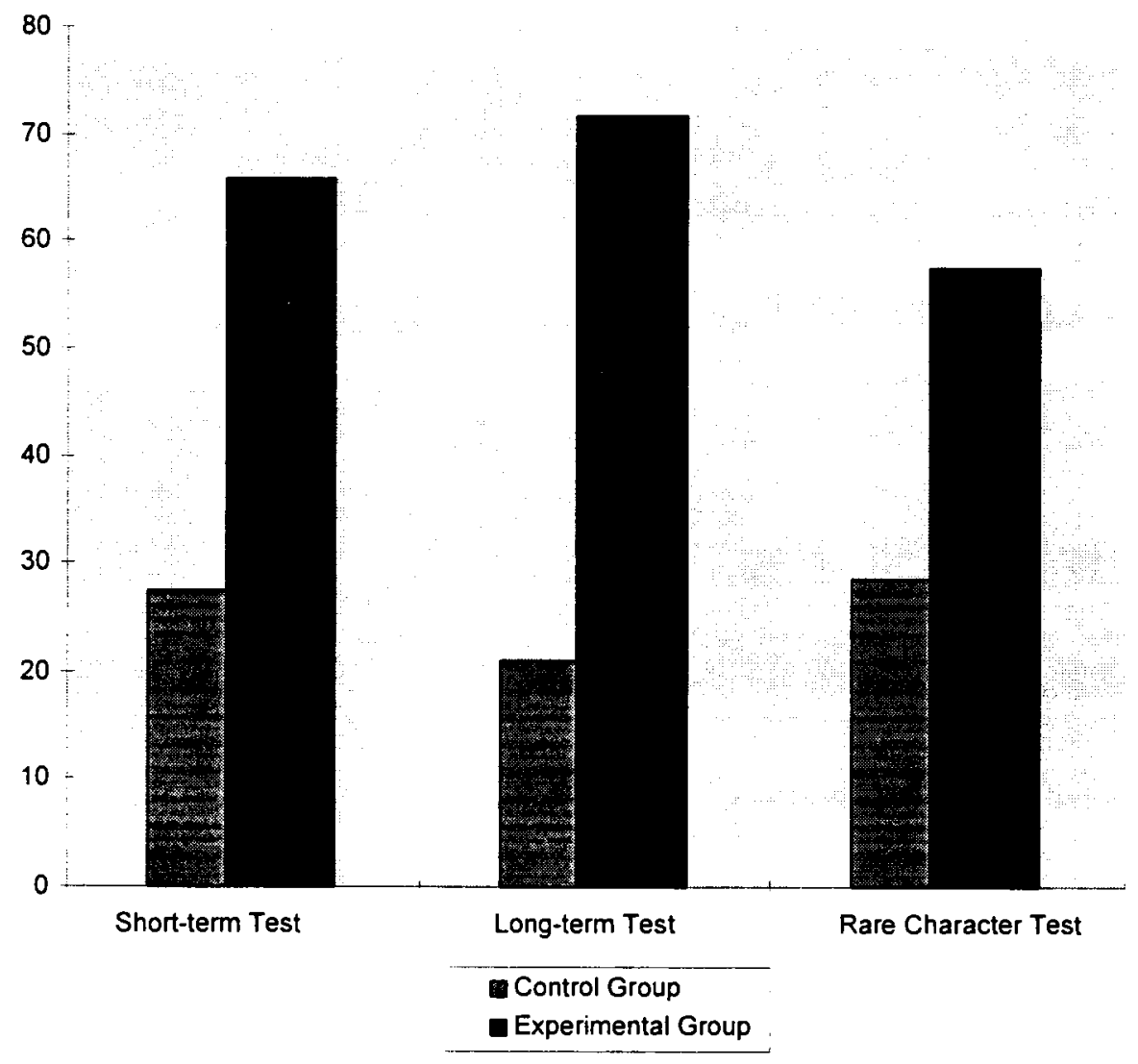


Summary

The students exposed to the two different teaching approaches performed differently at a statistically significant level. The experimental group recalled more characters on both the short-term test and the long-term test. Furthermore, the experimental group identified more accurately the pronunciation of more characters than the control group on the rare character test. It seems that the difference in the students performance on the three tests was influenced by the different teaching approaches.

The fact that the experimental group received instruction in phoneticideographic rules appears to be the contributing factor in the experimental group's superior performance on the short-term, long-term, and rare-character tests. The data collected therefore support all three hypotheses:

1. First-year Chinese students in the experimental group exposed to the CCRM method will recall more Chinese characters on the short-term test than will the first-year Chinese students in the control group taught by the traditional method.

2. First-year Chinese students in the experimental group exposed to the CCRM method will recall more Chinese characters on the long-term test than will the first-year Chinese students in the control group taught by the traditional method.

3. First-year Chinese students in the experimental group exposed to the CCRM method will perform more closely to the group of native Mandarin speaker on the rarecharacter test than will the first-year Chinese students in the control group. 


\title{
CHAPTER V
}

\section{DISCUSSION OF RESULTS}

\author{
Background Problem
}

For students of alphabetic languages, learning Chinese characters seems to be an enormous or even impossible task. When students wish to link the pronunciation to the printed character as they can in English, they often fail. The reason is that the pronunciation of a character is not represented as perceptibly as it is in English. The frustration over being unable to learn characters is often one of the biggest reasons that students quit in the middle of their study, or just simply give up the hope that they will one day master Chinese characters.

It has been found that native speakers analyze and process characters phonetically in the memory (Tzeng, Hung, Wang, 1977; F,d'Arcais, 1992; C.M. Cheng, 1992). Psychologically, a speaker of Mandarin Chinese predicts the pronunciation of a character through the phonetic element the character contains. There is a saying: "Du zi, you bian du bian, mei bian du zhong jian." It means "When there is an element on the side, pronounce the side. When there is nothing on the side, pronounce the middle." This saying suggests that some strategies are adopted by native speakers of Chinese to pronounce characters. 
A native speaker has a system in the memory that sorts out all the phoneticideographic rules which help to recall or predict the pronunciation more accurately. Likewise, after a period of study, learners of Chinese can pick up the ability to guess the pronunciation of characters. However, the input for learners of Chinese as a foreign language is not as plentiful as for native speakers. The process of forming the phoneticideographic rules in the memory is, therefore, slow. This may be the reason for the slow learning of characters for many students of Chinese.

\section{Purpose of the Study}

The purpose of teaching phonetic-ideographic rules to American students of Chinese is to help them learn characters better and more efficiently. Since non-native speakers are not on equal footing with native speakers, and since Chinese characters do seem difficult to master for students taught by traditional methods, a carefully designed teaching approach that can teach more efficiently and cause less anxiety and frustration is needed.

Hypotheses

All three hypotheses proposed in Chapter 1 were supported by the experiment. The first hypothesis held that students who were taught phonetic-ideographic rules would perform better on a short-term test than students who were not. The t-test 
produced statistically significant differences between the two groups. Hypothesis 1 was, therefore, supported.

The second hypothesis held that students who were taught the phoneticideographic rules would perform better on a long-term test than students who were not. The t-test produced statistically significant differences between the two groups. Hypothesis 2 was, therefore, supported.

The third hypothesis held that students who were taught the phoneticideographic rules would perform better on a rare-character test than students who were not. The t-test produced statistically significant differences between the two groups. Hypothesis 3 was, therefore, supported.

The acceptance of the research hypotheses is consistent with the results of the previous experiments carried out in Mainland China (Ye, 1990). The results of the experiments in Mainland China showed that students who had instruction on phoneticideographic rules recalled more pronunciation of Chinese Characters than students who were taught by the traditional method. These results accord with my supposition and data. Results in my experiment on second-language learners of Chinese revealed that students who were taught the phonetic-ideographic rules recalled more pronunciation of characters on both the short-term and long-term tests. Moreover, the experimental group predicted more pronunciations correctly than the control group.

The results of this study suggest that having explicit knowledge of the phonetic 
ideograph rules may be one of the factors that resulted in more efficient character learning and better retention.

\section{Findings}

The total scores on each test show students' overall performance; however, they do not present the different types of student answers. In order to examine the different types of answers, the tests were designed to allow students to generate their answers without the set formats or constraints of a standard multiple-choice test. This naturally and freely generated data could be used to look at how close students' answers were to the accurate answers.

Students' answers on the test were categorized into three types: correct answers, approximate answers, and incorrect answers. These are all presented in their percentages. Following is the table that shows how students' answers on the short-term test were distributed in these three categories. The numbers are percentages of one out of the thirty questions. For example, on the short-term test, the average percentages for one question answered by the experimental group show that $45 \%$ of answers were correct, $7.2 \%$ of answers were approximate answers, and $47.7 \%$ of answers were incorrect.

Observation 1:

Table 17 shows the average percentage distributed on each question. The average percentage of correct and approximate answers for the control group is $29.8 \%$. 
This percentage is lower than that of the experimental group, $52.2 \%$. However, in some questions, the control group has a performance that is close to that of the experimental group. These are questions $4,5,6,12,21,23,25,27,28$ and 29. They are shown in bold fonts in the table. On these questions, the control group has a high percentage of correct or approximate answers.

The same phenomenon is also found in the long-term test (See Table 18). The average percentage of correct and approximate answers for the control group is $12.55 \%$. This percentage is much lower than that of the experimental group, $50.76 \%$.

However, in some questions, the control group's performance is close to that of the experimental group. These are questions $7,11,21,28$. They are shown in bold fonts in Table 18. On these questions, the control group has higher percentages of correct and approximate answers. 
Table 17

Responses to Individual Questions on Short-term Test

\begin{tabular}{|c|c|c|c|c|c|c|c|}
\hline & \multicolumn{2}{|c|}{ Correct answers } & \multicolumn{2}{|c|}{ Approximate answers } & \multicolumn{2}{|c|}{ Incorrect answers } \\
\hline & & $\mathrm{C}$ & $E$ & $\mathrm{C}$ & $E$ & $\mathrm{C}$ & $E$ \\
\hline 1 & 安 wang & 23.2 & $\overline{88.3}$ & & & 76.8 & 11.7 \\
\hline 2 & 圍yu & 7.9 & 35.3 & 23 & 64.7 & 69.1 & \\
\hline 3 & 飼 $\mathrm{si}$ & 23.2 & 35.4 & & 29.4 & 76.9 & 35.2 \\
\hline 4 & 蜔 guo & 61.6 & 82.5 & & & 38.4 & 17.5 \\
\hline 5 & 東 zhong & 23.1 & 23.6 & & & 76.9 & 76.4 \\
\hline 6 & 胺 an & 61.6 & 47.1 & & & 38.4 & 52.9 \\
\hline 7 & 鮁 wei & 7.9 & 23.7 & 46.1 & 41.1 & 46 & 35.2 \\
\hline 8 & 磯 ji & 30.8 & 58.9 & & & 69.2 & 41.1 \\
\hline 9 & 笨 ben & 30.8 & 70.6 & & & 69.2 & 29.4 \\
\hline 10 & 景 jing & 23.2 & 53.1 & & 11.7 & 76.9 & 35.2 \\
\hline 11 & 瘤 liu & 15.4 & 53 & & & 84.6 & 47 \\
\hline 12 & 鵬 peng & 30.8 & 47.2 & & & 69.2 & 52.8 \\
\hline 13 & 蚊 wen & 53.9 & 82.4 & & & 46.1 & 17.6 \\
\hline 14 & 盯 ding & 30.9 & 76.6 & & & 69.1 & 23.4 \\
\hline 15 & 軻 ke & 15.4 & 29.5 & & & 84.6 & 70.5 \\
\hline 16 & 悝 li & 23.1 & 64.8 & & & 76.9 & 35.2 \\
\hline 17 & 袈 $\mathrm{jia}$ & 23.1 & 41.2 & & & 76.9 & 58.8 \\
\hline 18 & 姑 gu & 7.8 & 41.4 & & & 92.2 & 58.7 \\
\hline 19 & 眊 mao & 38.5 & 64.8 & & & 61.5 & 35.2 \\
\hline 20 & 筆 zheng & 30.8 & 35.4 & & 23.5 & 69.2 & 41.1 \\
\hline 21 & 怒 nu & 38.6 & 29.5 & & & 61.4 & 70.5 \\
\hline 22 & 岁 ji & 7.7 & 17.8 & & & 92.3 & 82.2 \\
\hline 23 & 毉 yi & 23.2 & 17.8 & & & 76.8 & 82.2 \\
\hline 24 & 逯lu & 23.2 & 47.1 & & & 76.9 & 52.9 \\
\hline 25 & 炸 zha & 23.1 & 11.9 & & 17.6 & 76.9 & 70.5 \\
\hline 26 & 稞 ke & 15.4 & 41.3 & & 11.7 & 84.6 & 47 \\
\hline 27 & 迴 hui & 38.5 & 17.7 & & & 61.5 & 82.3 \\
\hline 28 & 管 guan & 30.8 & 35.3 & & & 69.2 & 64.7 \\
\hline 29 & 誌 zhi & 30.9 & 29.5 & & & 69.1 & 70.5 \\
\hline 30 & 笔 sheng & 30.8 & 76.6 & & 17.6 & 69.2 & 5.8 \\
\hline \multicolumn{2}{|c|}{ Average } & 27.498 & 45.001 & 2.303 & 7.243 & 70.199 & 47.756 \\
\hline
\end{tabular}


Table 18

Responses to Individual Questions on Long-term Test

\begin{tabular}{|c|c|c|c|c|c|c|c|}
\hline & \multicolumn{2}{|c|}{ Correct answers } & \multicolumn{2}{|c|}{ Approximate answers } & \multicolumn{2}{|c|}{ Incorrect answers } \\
\hline & & $\mathrm{C}$ & $E$ & $\mathrm{C}$ & $\mathrm{E}$ & $\mathrm{C}$ & $E$ \\
\hline 1 & 撣 dan & $\overline{7.69}$ & 58.82 & & 5.88 & 92.3 & 29.41 \\
\hline 2 & 儷 & 7.69 & 58.82 & & 5.88 & 92.3 & 29.41 \\
\hline 3 & 濫 lan & 7.69 & 41.17 & & 5.88 & 92.3 & 47.05 \\
\hline 4 & 麥㫷 huang & 7.69 & 58.82 & & & 92.3 & 35.3 \\
\hline 5 & 玷 dian & 15.38 & 47.05 & & 17.64 & 84.6 & 29.41 \\
\hline 6 & 踩 cai & 7.69 & 52.94 & & 5.88 & 92.3 & 35.3 \\
\hline 7 & 票 piao & 30.76 & 41.17 & & 5.88 & 69.2 & 47.05 \\
\hline 8 & 喓 yao & 23.07 & 76.47 & 7.69 & & 69.2 & 17.64 \\
\hline 9 & 领 ling & 7.69 & 64.7 & & 5.88 & 92.3 & 23.53 \\
\hline 10 & 馥 fu & 7.69 & 17.64 & & & 92.3 & 76.47 \\
\hline 11 & 畔 pan & 30.76 & 11.76 & 7.69 & 76.47 & 61.5 & 5.88 \\
\hline 12 & 骸 hai & & 41.17 & 15.38 & 11.76 & 84.6 & 35.3 \\
\hline 13 & 販 fan & 15.38 & 52.94 & & 11.76 & 84.6 & 29.41 \\
\hline 14 & shi & 15.38 & 41.17 & 7.69 & 17.64 & 76.9 & 35.3 \\
\hline 15 & tang & 15.38 & 64.7 & 7.69 & & 76.9 & 29.41 \\
\hline 16 & 或 qiu & & 23.53 & & & 100 & 70.59 \\
\hline 17 & 猿 yuan & & 29.41 & & & 100 & 64.7 \\
\hline 18 & 醮 jiao & & 23.53 & & 5.88 & 100 & 64.7 \\
\hline 19 & 碁 qi & & 23.53 & & 11.76 & 100 & 58.82 \\
\hline 20 & 松 song & & 29.41 & 7.69 & 5.88 & 92.3 & 58.82 \\
\hline 21 & 情 qing & 23.07 & 47.05 & & & 76.9 & 47.05 \\
\hline 22 & 縭 li & & 47.05 & & & 100 & 47.05 \\
\hline 23 & 房 fang & 15.38 & 35.3 & & & 84.6 & 58.82 \\
\hline 24 & 鯄 lai & 7.69 & 64.7 & 7.69 & & 84.6 & 29.41 \\
\hline 25 & 雹 bao & 7.69 & 58.82 & 7.69 & & 84.6 & 35.3 \\
\hline 26 & 幡 fan & & 23.53 & & 5.88 & 100 & 64.7 \\
\hline 27 & 齠 $\mathrm{yu}$ & 15.38 & 17.64 & 7.69 & 41.17 & 76.9 & 35.3 \\
\hline 28 & 寰 huan & 15.38 & 29.41 & 7.69 & 5.88 & 76.9 & 58.82 \\
\hline 29 & 騎 qi & & 11.76 & 7.69 & 17.64 & 92.3 & 64.7 \\
\hline 30 & 靶 ba & & 47.05 & & 17.64 & 100 & 29.41 \\
\hline \multicolumn{2}{|c|}{ Average } & 9.484 & 41.368 & 3.076 & 9.409 & 87.423 & 49.223 \\
\hline
\end{tabular}


Observation 2:

One explanation for the answers found on the tests of the control group are that some students in the control group mistook radicals for the phonetic stem. Table 19 is a demonstration of some answers found on students' tests:

Table 19

Examples of Control Group's Errors

\begin{tabular}{|c|l|l|}
\hline questions & Pronunciation & Students' answers \\
\hline 妄 & wang & nü \\
\hline 景 & jing & ri \\
\hline 怒 & nu & xin \\
\hline 岁 & ji & shan \\
\hline 姑 & $\mathrm{gu}$ & nü \\
\hline
\end{tabular}

These answers may suggest that students who were not taught the phoneticideographic rules also were looking for clues to the pronunciation; however, lacking the knowledge of phonetic-ideographic rules, they chose the wrong element.

\section{Finding:}

Observation 1 and observation 2 on the performance of the control group may indicate that students were forming some rules without being taught the phoneticideographic rules. Larsen-Freeman and Long (1994) refer to Chomsky's theory about language acquisition, and suggest that second language learning, similar to first language learning, is also a product of rule formation. They state "Chomsky posited a theory in 
which humans were thought to possess a certain innate predisposition to induce the rules of the target language from the input to which they were exposed" (p.57).

In his book about the psychological theory of Chinese processing, Ye (1990) suggests that the Chinese saying "You bian du bian, mei bian du zhong jian" may be a reflection of the psychological process native speakers go though while pronouncing a Chinese character. This supports Chomsky's theory about the innate predisposition of humans to form rules from the input. In other words, when encountering a Chinese character, one looks for the phonetic element in order to pronounce the character. On the rare-character test of my experiment, the native speakers indeed outperformed the other two groups. This may also explain why some of the control group students seemed to look for the phonetic stems and wrote answers that were close to the accurate answers.

Although the control group appeared to have formed their own rules to pronounce characters, and performed well on some questions, their overall performance was significantly lower than that of the experimental group. This may suggest that with the help of phonetic-ideographic rules, students in the control group may be able to get more correct and approximate answers.

\section{Observation 3:}

In addition to the quantifiable test scores collected which show that CCRM is a more efficient way of teaching Chinese, other observations of a non-quantifiable nature are also valuable and should be discussed. They are students' reactions toward CCRM 
versus the traditional approach, and the method that students found easier to learn.

It was obvious, according to my observation, that students taught by the traditional method experienced greater frustration and had less confidence than did students in the experimental group. Many students in the control group found it difficult to memorize the large number of characters taught in the character packet. The following are some complaints and reactions cited from the control group students.

"How are we going to memorize so many characters!?"

"Man, this is impossible!"

"I know I'm gonna do very bad. I hope I don't mess up your research."

Students taught by the Concentrated Character Recognition Method, unlike the control group, showed great interest and confidence in the character learning sessions. Many students came to class with a high level of energy and spirit. They appeared to enjoy the instruction on phonetic-ideographic rules, and enjoyed the activities on learning the phonetic stem. The following are some student reactions to the learning of phonetic-ideographic rules:

"This is interesting and helpful!"

"I have learned so much more in one term than I did in a year!"

"Cai lao shi (teacher cai), I spend a lot of time studying the phonetic stem in the character packet, I hope I can do OK on the test."

Although students in the control group, unlike the experimental group, found memorizing the pronunciation difficult, students of both groups seemed to appreciate 
the lessons on radicals. Both groups expressed great interest in learning radicals, and participated enthusiastically in the character learning activities. With the absence of instruction on phonetic-ideographic rules, the control group received much more practice on the radicals than the experimental group. Regardless of the frustration of sound memorization, students in the control group seemed to enjoy the lessons on character learning.

Based on both the quantifiable findings and my observations throughout the treatment, it is my opinion that teaching phonetic-ideographic rules is popular with students, and was indeed beneficial to the students in this study.

\section{Limitations to the Study}

There are some limitations to this study. First, it was the investigator's ideal to continue this study through a longer period of time. However, this research was done in one academic quarter because some students do not continue to study Chinese after one quarter is over, and students often switch to a different class due to their personal class schedule. For these reasons, carrying out the research beyond one academic quarter was not an option for the investigator.

Some students in the experimental group did not write down the pronunciation, instead, they circled the phonetic stems. This implies that students were able to tell which was the phonetic element; however, one term was not long enough for them to memorize the pronunciation. 
There are other factors related to the behaviors and motivations of the students that might have also affected the results of the study. The first one was that some students were absent and thus missed some classes that might have affected their performance on tests. Moreover, students were aware that none of the test scores would affect their final grades; thus they might not have taken the tests as seriously as they would have if the tests could affect their grades. This was especially serious when the long-term test was held. Due to the schedule, the long-term test was held close to the final exam week at the university. Since their final exam was very important in terms of deciding their grades, it was very possible that students might not have taken the character test as seriously as they did their final exam. After the test, some students told the investigator that they did not have time to study for the long-term test.

\section{Conclusion}

For native speakers of Mandarin Chinese, the subconscious knowledge of phonetic-ideographic rules helps them in memorizing, recalling, and guessing the pronunciation of Chinese characters. Moreover, the explicit teaching of phoneticideographic rules was found to be beneficial to native speakers of Chinese. It was found in this study that the teaching of phonetic-ideographic rules was beneficial also to learners of Chinese as a second language.

The results of this study show that the Concentrated Character Recognition Method benefits students in terms of character learning more than the traditional 
approach. Students in the experimental group outperformed their counterparts in the control group on all three tests: short-term, long-term, and rare character tests.

One thing suggested by this study is that the conscious knowledge of phoneticideographic rules may help American students of Chinese to recall and predict Chinese characters in a way that is close to the proficiency level of a native speaker.

Teaching phonetic-ideographic rules can strengthen the link between the printed characters and the pronunciation.

The learning of phonetic-ideographic rules can be especially beneficial to American students of Chinese who are used to learning words with phonological hints provided in the print.

Overall, I believe that having the knowledge of phonetic-ideographic rules will not only improve character retention, and help to predict new characters more accurately, but also, it will give students more confidence and control in learning Chinese characters. Too much frustration and anxiety could make learning more difficult and less successful. Learning phonetic-ideographic rules can increase the confidence level of learning.

\section{Recommendations for Further Study}

One limitation of this study was that the experiment lasted for only one academic quarter. The investigator is curious about the results of an experiment that 
lasts more than one academic quarter. Might the results be different if the treatment is longer, and students have more time to demonstrate their progress?

This study was carried out on first-year learners of Chinese who had very little or no knowledge of phonetic-ideographic rules. What effect would knowledge of phonetic-ideographic rules have on learners who already have studied Chinese for more than a year and have unconsciously formed some phonetic-ideographic rules? More research could also be conducted on advanced students to find out how well they apply phonetic-ideographic rules. 


\section{REFERENCES}

Chao, Y. R. (1968). Language and Symbolic Systems. New York: Cambridge University Press.

Cheng, C. M. (1992). Lexical Accession Chinese: Evidence from Automatic Activation of Phonological Information. In Chen, H. C. \& Tzeng, O. J. L. (Eds.), Language Processing in Chinese. Amsterdam: Elsevier Science Publishers B.V..

Deng He (1992). (3rd. ed). Zhongguo wenzi jiegou xuanjie (series 2, 2nd ed). Taipei: Zheng Chung Book Co..

Feitelson, Dina. (1976). (ed.). Cross-Cultural Perspectives on Reading and Reading

Research. Newark, Delaware: International Reading Association, Inc..

Flores d'Arcais (1992). Graphemic, Phonological, and Semantic Activation Processes during the Recognition of Chinese Characters. In Chen, H. C. \& Tzeng, O. J. L. (Eds.), Language Processing in Chinese. Amsterdam: Elsevier Science Publishers.

Foss, Donald. J. \& Hakes, David. T. (1978). Psycholinguistics: An Introduction to the Psychology of Language. Englewood Cliffs: Prentice-Hall, Inc..

Fromkin, V. \& Rodman, R. (1988). An Introduction to Language. (4th ed.).

Orlando: Holt, Rinehart and Winston, Inc..

Garman, M. (1990). Psycholinguistics. Cambridge: Cambridge University Press. Gelb, I.J. (1952). (2nd ed.). A Study of Writing. Chicago: University of Chicago Press.

Gleason, B. J. \& Ratner, B. N. (1993). Psycholinguistics. Orlando: Harcourt Brace Jovanovich College Publishers. 
Greenberg, B. (1987). Using Microcomputers and Mainframes for Data Analysis in the Social Science. Columbus, Ohio: Merrill Publishing Company. Greenberg, J. H. (1966). (ed.). Universals of Language (2nd ed.). Cambridge: M.I.T Press.

Henshall, K. G. (1988). A Guide to Remembering Japanese Characters. Tokyo: Charles E. Tuttle Company, Inc..

Hoosain, R. (1991). Psycholinguistic Implications for Linguistic Relativity: A Case Study of Chinese. Hillsdale, New Jersey: Lawrence Erlbaum Associates, Inc., Publishers.

Huang Yong-Wu. 黄永武. (1984). Xingshengduojian huiyi kao. (5th ed). Taipei: Wen-shih-che Pub. co..

Hung, D. L., Tzeng, O. J. L., \& Tzeng, A. K. Y. (1992). Automatic Activation of Linguistic Information in Chinese Character Recognition. In Frost, R. \& Katz, L. (Eds.), Orthography, Phonology, Morphology, and Meaning. Amsterdam, The Netherlands: Elsevier Science Publishers B. V..

Krashen Stephen. (1981). Second Language Acquisition and Second Language Learning. New York: Pergamon Press Inc..

Ladefoged, P. (1993). A Course in Phonetics (3rd ed.). Orlando, Florida: Harcourt Brace \& Company.

Laychuk, J. L. (1983). The Use of Etymology and Phonetic Symbols (Zhuyin Fuhao) in Teaching First Year Chinese. U. S. Department of Education National Institute of Education.

Leong , C.K. (1976). Learning to Read in English and Chinese: Some Psycholinguistic and Cognitive Considerations. In Feitelson, Dina. (ed.). Cross-Cultural Perspectives on Reading and Reading Research (pp. 157 - 173). Newark: International reading Association, Inc.. 
Li Xiao Ding. (1977). Hanzi shihua. Taipei: Lien-ching Pub. co..

Li, C. N. \& Thompson, S. A. (1989). Mandarin Chinese: A Functional Reference Grammar. Berkeley: University of California Press.

Liang Dong-han 梁東漠 (1991). Hanzi di jiegou ji qi liubian. Shang-hai: Shanghai Jiaoyu Chubanshe.

Liu. Stella. S.F. (1976). Decoding and Comprehension in Reading Chinese. In Feitelson, Dina. (ed.). Cross-Cultural Perspectives on Reading and Reading.

Research. Newark, Delaware: International reading Association, Inc..

Luo zhao-jin 羅歪錦. (1990). Taiwan qu Shengshili Shifan xueyuan qishiba xueniandu Zhongguo yuwen yanxihui baogao shu. Taipei: Taiwan sheng zhengfu jiaoyuting.

Norman Jerry. (1988). Chinese. Cambridge: Cambridge University Press,.

Nunan, D. (1995). Research Methods in Language Learning. Cambridge: Cambridge University Press.

Osgood, Charles. E. (1966). Language Universals and Psycholinguistics. In Greenberg, Joseph. H. (ed.). Universals of Language (2nd ed.). Cambridge: The M.I.T. Press.

Qiu De-Xiu. 邱德修. (1995). Wenzixue xindan. Taipei: Ho-chi Pub. Co.. Rozin, P.,Poritsky, S., Sotsky, R. (1973). American Children with reading problems can easily learn to read English represented by Chinese characters. In Smith, F. (ed). Psycholinguistics and Reading (pp. 105 - 115). Holt, Rinehart and Winston, Inc.

Scribner, S. \& Cole, M., (1981). The Psychology of Literacy Cambridge: Harvard University Press.

Seymour, N. N. (1989). How to Identify Chinese Characters. Metuchen, N. J., \& London: The Scarecrow Press. 
Shankweiler, Donald \& Liberman. Isabelle Y., (1989). (eds.). Phonology and Reading Disability: Solving the Reading Puzzle. University of Michigan Press.

Stahl, M. S. \& Hennes, D.J. (1975). Reading and Understanding Applied Statistics: a self-learning approach. Saint Louis: The C.V. Mosby Company.

Tang Ting-Chi 湯廷池 (1987). The World of Chinese Language. (no.44). Taipei: Hua-wen shih-chieh Journal.

Thern, K. L. (1966). Postface of the Shuo-Wen-Chieh-Tzu The First Comprehensive Chinese Dictionary. Madison, Wisconsin: Department of East Asian Languages and Literature. University of Wisconsin.

Tsai Ya-Lin 蔡雅森 (1986). The World of Chinese Language. (no. 40). Taipei: Hua-wen shih-chieh Journal.

Tzeng , Ovid. J.L. \& Singer, Harry. (1981). (eds.). Perception of Print: Reading Research in Experimental Psychology, Hillsdale, New Jersey: Lawrence Erlbaum Associates, Inc..

Tzeng, Ovid J.L., Hung, D.L. \& Wang, W. S-Y. Speech recoding in Reading Chinese Characters. Journal of Experimental Psychology: Human Learning and Memory. 1977, Vol. 3, No. 6, 621-630.

Wang, William. S-Y. (1981). Language Structure and Optimal Orthography. In Tzeng, Ovid. J.L. \& Singer, Harry. (eds.), Perception of Print: Reading Research in Experimental Psychology (pp. 223 - 236). Hillsdale, New Jersey: Lawrence Erlbaum Associates, Inc..

Ye De-Ming 葉德明 (1990). Hanzi renzhi jichu: cong xinli yuyanxue kan Hanzi renzhiguoxheng. Taipei: Shih-ta shu-yuan Pub. Co.

Zhou He 周何 (1992). Zhongwen zigen ziru biaogao. Taipei: National Central Library. 
Zirps, Fotena. A. \& Wagner, Richard. K. (1989). Dual-Route, ACT, and PDP Models of the Acquisition of Word Decoding Skills. In Leong, C.K. \& Randhawa, Bikkar,. S. (eds.). Understanding Literacy and Cognition (pp. 157 - 172). New York: Plenum Press. 
APPENDIX A

INFORMED CONSENT FORM 
CONSENT FORM

I, agree to take part in this research project on

Teaching Chinese Phonetic-ideograph Rules to English-speaking Students.

I understand that the study involves instructions on Chinese characters, one pretest, one short-term test, one long-term test, and one rare-character test. I am also informed that I will be getting thirty minutes of instruction on Chinese phonetic-ideographic rules every week, and the evaluation will take place over the eleven week period.

Jillian Ji-fen Tsai has told me that the purpose of this study is to learn phoneticideographic rules which may help me recognize the pronunciation of Chinese characters.

I may not receive any direct benefit from taking part in this study. But the study may help to increase knowledge that may help others in the future.

Jillian Ji-fen Tsai has offered to answer any questions I have about the study and what I am expected to do. She has promised that all information I give will be kept confidential to the extend permitted by law, and that the names of all people in the study will be kept confidential.

I understand that I do not have to take part in this study, and that I may withdraw from this study without affecting my course grade or my relationship with Portland State University.

I have read and understand the above information and agree to take part in this study.

Date:

Signature:

If you have concerns or questions about this study, please contact the chair of the Human Subjects Research Review Committee, Research and Sponsored Projects, 105 Neuberger Hall, Portland State University, 503/725-3417. You may also contact the researcher, Jillian Ji-fen Tsai, at 725-7715. 
APPENDIX B

CHINESE CHARACTER PRETEST 
Chinese Characters Pretest

\begin{tabular}{|c|c|}
\hline 1. 谷 & 16. \\
\hline 2. 色 & 17. \\
\hline 3. 百 & 18. \\
\hline 4. 方 & 19. \\
\hline 5. 都 & 20 . \\
\hline 6. 早 & 21. \\
\hline 7. 乾 & 22. \\
\hline 8. 看 & 23. \\
\hline 9. 本 & 24. \\
\hline 10. 句 & 25. \\
\hline 11. 塊 & 26. \\
\hline 12. 媽 & 27. \\
\hline 13. 明 & 28. \\
\hline 14. 筆 & 29. \\
\hline 15. 努 & 30. \\
\hline
\end{tabular}


APPENDIX C

THE SHORT-TERM CHARACTER RECALL TEST 
Name:

Class :

1. 安

a. a female dancer

b. death

c. false, reckless

d. to marry

3. 飼

a. to wait upon

b. a company

c. phrases

d. to feed

5. 表

a. inner garment

b. in between

c. sign, to show

d. a huge bird

7. 鮁

a. to have

b. name of a river

c. meat

d. tuna fish

9. 笨

a. phoenix

b. stupid, dull

c. measure word for books

d. mole
2. 圄

a. to imprison

b. I, me

c. enclosure

d. Chinese language

4. 蟈

a. nationality

b. to slap

c. cricket, grasshopper

d. to circle

6. 胺

a. quiet

b. amine (chemical)

c. gas

d. cattle

8. 磯

a. to hit, to crush

b. how many

c. a tall mountain in China

d. jetty, breakwater

10. 景

a. capital of a country

b. view, prospects

c. movies

d. to forgive 
11. 瘤
a. tumor
b. roof
c. pomegranate
d. to keep, to maintain

13. 蚊
a. article
b. to smell
c. mosquito
d. ripples on water

\section{5. 軻}
a. an ax-handle
b. big rivers
c. a pair of wheels
d. maybe

\section{7. 袈}
a. to add more
b. strength
c. dress worn by monks
d. to fight fiercely

19. 眊
a. dull, dim-sighted
b. to crawl, creep
c. hair on face
d. aged people

\section{1. 怒}
a. to strive, exert
b. baby girls
c. slaves
d. anger, rage

12. 鵬
a. friends
b. animal meat
c. huge fabulous bird
d. long snake with feet
14. 盯
a. a single person
b. a surname
c. sun light
d. to keep ones eye on

16. 悝
a. a Chinese mile
b. to pity, feel sad
c. carp fish
d. inside, lining

18. 姑
a. wild mushrooms
b. aunt, girl
c. ancient trees
d. to deceive

20. 筆
a. kites
b. hibiscus (type of flower)
c. children
d. to fight for

22. 苃
a. grade, step
b. mountain top
c. and, also
d. mountain chicken 


\section{3. 毉}
a. king
b. black stone like jade
c. vinegar
d. doctors

25. 炸
a. to do
b. yesterday
c. to draw, to pull
d. to deep fry

27. 迴
a. whirlpool
b. enclosure
c. to return
d. to close the mouth

29. 痣
a. magazine
b. thigh bones
c. mole (on the face)
d. dried meat

24. 逯
a. to record
b. dark green
c. to go carefully
d. official salary

26. 稞
a. fruits on the tree
b. lessons
c. a name applied to many trees
d. grain ready for grinding

28. 管
a. a tube, flute
b. hall
c. officer
d. metal boxes

30. 笙
a. to give birth to children
b. new, raw
c. a wild flower
d. a Chinese musical instrument 
APPENDIX D

THE LONG-TERM CHARACTER RECALL TEST 
Class :

Name:

1. 撣
a. to dust
b. single
c. to bounce
d. Sheet, blanket

3. 濫
a. dishes
b. to overflow
c. lamp, light
d. sand

5. 玷
a. a shop
b. to stand
c. hall
d. a flaw in jade

2. 偠
a. name of a place
b. various colors
c. a married couple
d. to grasp

\section{4. 德}
a. yellow
b. beer
c. barley
d. springs

\section{6. 踩}
a. many-colored material
b. to step on
c. rake without teeth
d. to mutter, mumble

7. 飄
a. west gate
b. a kind of insect
c. tickets
d. to whirl in the air

9. 命弱
a. a feather
b. to order
c. large horned-owl
d. antelope

8. 喓
a. chirping of grasshopper
b. to want
c. fat, swollen
d. beautiful woman

10. 馥
a. belly
b. to repeat
c. fragrance
d. ripe grain 
11. 畔
a. windows
b. to stir
c. half
d. a path dividing fields

13. 販
a. to listen, hear
b. meals
c. a film over the eye
d. to trade, sell

\section{5. 塘}
a. a dynasty in Chinese history
b. pond
c. soup
d. to put out fire

\section{7. 猿}

a. robe

b. far

c. ape

d. to put off

19. 菪
a. game of chess
b. to chew, munch
c. to cheat
d. a fabulous animal

12. 䯓
a. rotten meat
b. ought to, should
c. bones of the body
d. air bladder of fish

16. 荠
a. a pool
b. a ball
c. to beg for
d. fur garment

18. 醮
a. to scorch
b. to sacrifice
c. west wind
d. to roast meat

20. 松
a. male mountain chicken
b. luxurious growth of vegetation
c. pine tree
d. to lift, raise

21. 情
a. dark blue
b. affections, feelings
c. to stir, mix
d. to bribe

22. 縭

b. bridal ornament

c. small bird

d. grass and weeds a. to leave 
23. 房
a. squares
b. to spin, weave
c. house, room
d. to loosen

25. 雹
a. to run
b. to wrap
c. clear, pure
d. hail stones

27. 䶣
a. irregular teeth
b. five people
c. shark
d. strong liquor

29. 騎
a. partridge
b. to ride
c. big deer
d. uneven, rough

24. 鯠
a. timber for boats
b. name of a river
c. rice fields
d. a kind of eel

26. 幡

a. to upset, open

b. tomato

c. a banner

d. dragon-fly

28. 寰
a. a hole, nest
b. a gate
c. to return
d. a large domain

30. 靶
a. target
b. scar
c. a wheel
d. a last name 
APPENDIX E

THE RARE CHARACTER TEST 
96

1. 角乍

2. 基

3. 未扣

4. 香分

5. 來力

6. 拫

7. 医没

8. 垃

9. 齒可

10. 棟

11. 午周

12. 古缶

13. 監

14. 捾

15. 黑犬
16. 來果

17. 领

18. 兵

19. 雷

20. 鹿

21. 鲁

22. 小本

23. 生生

24. 镸名

25. 渞

26. 攽

27. 蝶

28. 占又

29. 侑

30. 登毛 
APPENDIX F

CURRICULUM (CONTROL GROUP) 
Schedule for the Control Group

1. First class: Introduction of Radicals (Based on Mathews' Chinese English Dictionary)

2. Introduction of 12 commonly seen radicals.

3. Introduction of 12 more commonly seen radicals.

4. Introduction of 11 more commonly seen radicals.

5. Characters containing 5 commonly seen radicals.

6. Characters containing 5 commonly seen radicals

7. Characters containing 5 commonly seen radicals

8. Characters containing 2 commonly seen radicals

9. Characters containing 5 commonly seen radicals

10. Characters containing 3 commonly seen radicals

11. Characters containing 4 commonly seen radicals

12. Characters containing 3 commonly seen radicals

13. Characters containing 5 commonly seen radicals

14. More radicals: 16 less commonly seen radicals.

15. More radicals: 18 less commonly seen radicals.

16. More radicals: 26 less commonly seen radicals.

Mathews, R.H. (1943). Mathews' Chinese English Dictionary Cambridge: Harvard University Press. 


\section{LESSON PLAN C-1}

Class: First-year Chinese class at the university.

Time: 25 minutes.

Teaching Objective: To teach students how to identify the position of radicals.

Teaching Materials: Handouts of ways of finding radicals.

\section{Handout:}

* The Radical is from the list of $\mathbf{2 1 4}$ Radicals, the Phonetic is the other half of the character. The Phonetic can sometimes be another Radical itself, as in 近記理罵

* The Radical should give a clue to the meaning of a character 。

* A good deal of difficulty will be found in knowing under what radical to look for any particular character. The radical may occupy any part of the character.

It may be at the top, as 竹 in 管 or at the bottom, as 血 in 監 on the left, as 糸 in 給 on the right, as 邑 in 都 surrounding it, as $\square$ in 固 or in the middle of it, as $\square$ in 周 partially surrounding it, as $\%$ in 痕 or the radical may be split in two, enclosing the phonetic, as 衣 in 裏 Sometimes it is mixed up with the phonetic, as $\Pi$ in 再

\section{How to find the Radical:}

1. First you have to consider whether the character is a radical itself. Thus 音香高 辛玉 are themselves radicals.

2. If the character is not a radical, the next step is to break it into two parts. In two cases out of three there will be one part on the right hand and another on the left such as 他理江. Or the division may be horizontal, one half being above, the other beneath, and in this case the division is not quite so simple as in 告答 罪 靈. Or one half may enclose the other on two or more sides, as 有反道 
3. If one of the two parts is a radical and the other is not, obviously we must look for it under that part which is a radical; as, 白金心 which come from 的釘忽 respectively, the other halves not being radicals.

4. If both halves of a character are radicals, the following rules may be applied:

a. If the character consists of a right-hand and a left-hand half, The left-hand half is usually the radical; as, for instance, 信加快 如律性拉明根

!!!Exceptions: The radicals 刀力文斤欠邑隹鳥投 are generally found on the right side of the character, but they are often the radical.

*The rule that the left-hand portion of the character is the radical also holds in cases where the radical extends to two or more sides of the character 庫建房連.

b. If the character consists of an upper and lower half, both being radicals, the lower half is usually the radical. As, for instance, 思昏季果泉冬

!!!Exceptions: The following radical are placed at the top of the character , and they are the radicals: 㖄竹穴四 雨爪二立.

* These rules will dispose of $95 \%$ of the characters. 


\section{LESSON PLAN C-2}

Class: First-year Chinese class at the university.

Time: 25 minutes

Teaching Objective: To teach 12 radicals and provide examples.

Teaching Materials: Blackboard.

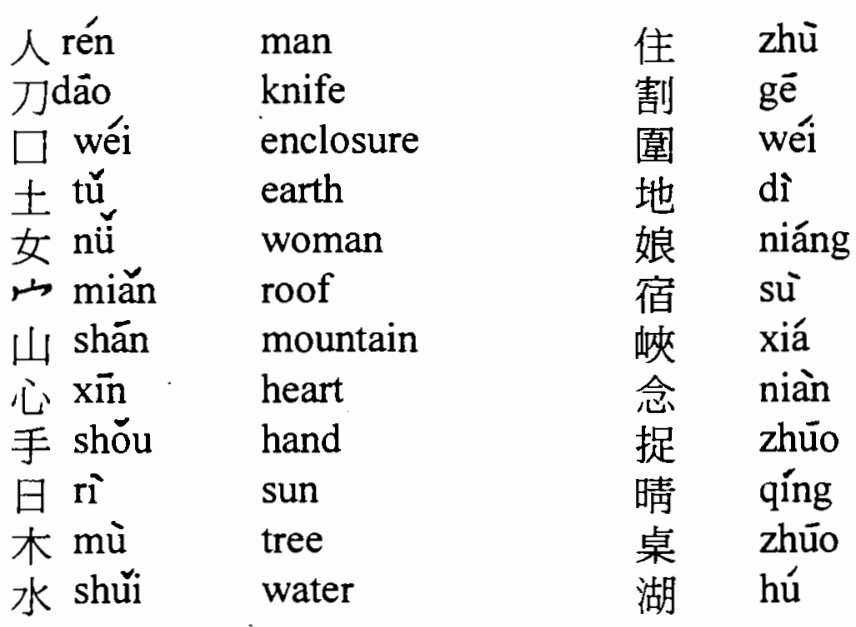

\section{Procedures:}

I. Show students how radicals represent real objects, draw pictures on the board.

II. Practice pronouncing radicals, and give the meaning.

III. Provide with examples containing the radicals, and point out where they locate in each character. 


\section{LESSON PLAN C-3}

Class: First-year Chinese class at the university.

Time: 25 minutes

Teaching Objective: To review 12 radicals in the first lesson.

To teach 12 more radicals and provide examples.

Teaching Materials: Blackboard.

\begin{tabular}{|c|c|c|c|}
\hline 火 hũo & fire & 者 & zhú \\
\hline 犬 quăn & $\operatorname{dog}$ & 獵 & liè \\
\hline 玉 yù & jade & 珠 & zhū \\
\hline 广 chuáng & disease & 痛 & tòng \\
\hline 目 mù & eye & 睡 & shùi \\
\hline 示 shì & sign & 神 & shén \\
\hline 禾 hé & grain & 種 & zhòng \\
\hline 竹 zhú & bamboo & 筆 & \\
\hline 系 mi & silk & 綁 & bang \\
\hline 肉 ròu & meat, flesh & 肝 & gān \\
\hline 岖 căo & grass & 芬 & fen \\
\hline 虫 hưi & insect & 蟋 & $x^{1}$ \\
\hline
\end{tabular}

\section{Procedures:}

I. Review old radicals:

Write radicals on the board and ask students to identify them, and to say what they represent, until students are familiar with the radicals.

II. Teach new radicals:

1. Show students how radicals represent real objects, draw pictures on the board.

2. Practice pronouncing radicals, and give the meaning.

3. Provide with examples containing the radicals, and point out where they locate in each character. 


\section{LESSON PLAN C-4}

Class: First-year Chinese class at the university.

Time: 25 minutes

Teaching Objective: To review 24 radicals in the previous lessons.

To teach 11 more radicals and provide examples.

Teaching Materials: Blackboard.

$\begin{array}{llll}\text { 衣 yī } & \text { clothing } & \text { 裙 } & \text { qún } \\ \text { 言 yán } & \text { speech } & \text { 語 } & \text { yú } \\ \text { 車 ché } & \text { vehicle } & \text { 輪 } & \text { lún } \\ \text { 之 chùo } & \text { halt } & \text { 逃 } & \text { táo } \\ \text { 金 jīn } & \text { metal, gold } & \text { 銀 } & \text { yín } \\ \text { 食 shí } & \text { food } & \text { 飯 } & \text { fàn } \\ \text { 馬 má } & \text { horse } & \text { 騎 } & \text { qí } \\ \text { 魚 yú } & \text { fish } & \text { 鮮 } & \text { xiān } \\ \text { 鳥 niăo } & \text { bird } & \text { 鴕 } & \text { túo } \\ \text { 口 kǒu } & \text { mouth } & \text { 喝 } & \text { hē } \\ \text { 石 shí } & \text { stone } & \text { 砲 } & \text { paò }\end{array}$

\section{Procedures:}

I. Review old radicals:

Write radicals on the board and ask students to identify them, and to say what they represent, until students are familiar with the radicals.

II. Teach new radicals:

1. Show students how radicals represent real objects, draw pictures on the board.

2. Practice pronouncing radicals, and give the meaning.

3. Provide with examples containing the radicals, and point out where they locate in each character. 


\section{LESSON PLAN C-5}

Class: First-year Chinese class at the university.

Time: 25 minutes

Teaching Objective: To review 35 radicals taught in the previous lessons.

To teach characters containing radicals, 刀土人口 女.

Teaching Materials: First lesson in the Control Group Character Packet.

Transparency of Lesson 1.

Lesson 1:

Radical: 刀

Radical:

剛 gāng

剽 piào

判 pàn

刻 $\mathrm{ke}$

利 lì

Radical: 土

基 $\mathrm{ji}$
城 chéng
塘 táng
塾 shú
墦 fán

Radical: 人

伍 wŭ

傌 mà

仔 zì

伺 sì / cì

仲 zhòng

何 hé

伽 jiā

倀 chāng

伋 jí

作 zùo

倌 guān

僄 piào

伯 bó solid, firm

to rob

to judge

to carve

sharp

foundation

city, town

pond

school

grave

five people

to scold

careful

to wait upon

mid, second

which

Buddist term

rash, wildly

empty, unreal

to write

animal keeper

light, airy

uncle

\begin{tabular}{lll} 
圍 & yŭ & to imprison \\
國 & gúo & country \\
直 & youu & limited \\
回 & húi & to return \\
囚 & qiú & prisoner \\
图 & líng & jail \\
\hline
\end{tabular}

Radical: 女

$\begin{array}{lll}\text { 媽 } & \text { mā } & \text { mother } \\ \text { 娜 } & \text { nà } & \text { elegant } \\ \text { 姑 } & \text { gũ } & \text { aunt } \\ \text { 嫛 } & \text { yì } & \text { new born baby } \\ \text { 嫖 } & \text { piáo } & \text { to visit prostitutes } \\ \text { 媳 } & \text { xí } & \text { daughter in law } \\ \text { 嫚 } & \text { màn } & \text { to scorn, insult } \\ \text { 姓 } & \text { xìng } & \text { last name } \\ \text { 娌 } & \text { lî } & \text { wifes of brothers } \\ \text { 娥 } & \text { é } & \text { beautiful woman }\end{array}$




\section{Procedures:}

I. Review 35 radicals:

1.Give each students cards written with characters containing different radicals.

2.Students first identify the radicals contained in the characters written on their card, and then they circle around the class, and find the student whose character contains the same radical.

3. When two characters that contain the same radical are matched, students put them on the board, and later read them to the class.

II. Teach characters containing the following radicals: 刀土人口女.

1. Review the pronunciation and the meaning of the radicals.

2. The teacher says one character in its English definition, and let students say which radical the character contains. For example, the teacher says " to carve". and the students answer " the character has the radical 刀(knife)."

3. Then students find the character that ha the meaning "to carve", and pronounce it.

4. This keeps going until students are familar with the radicals, and can make their judgement quickly and accurately. 


\section{LESSON PLAN C-6}

Class: First-year Chinese class at the university.

Time: 25 minutes

Teaching Objective: To review characters containing radicals, 刀土人 $\square$ 女. To teach characters containing radicals, 人日山穴

Teaching Materials: Lesson 2 in the Control Group Character Packet. Transparency of Lesson 2.

Lesson 2

Radical: 人

Radical: $\dot{ }$

$\begin{array}{ll}\text { 伶 } & \text { líng } \\ \text { 供 } & \text { gòng } \\ \text { 侍 } & \text { shì } \\ \text { 傏 } & \text { táng } \\ \text { 俅 } & \text { qiú } \\ \text { 侷 } & \text { jú } \\ \text { 佼 } & \text { jiāo } \\ \text { 傚 } & \text { xiào } \\ \text { 估 } & \text { gũ } \\ \text { 俄 } & \text { è }\end{array}$

actors

to lay offerings

頉 wù to be awake

to serve

to ward off

ornamental cap

narrow, cramped

handsome

to imitate

to estimate

Russia.

Radical: 日

晤 wù

星 xing

晾 liàng

昨 zúo

晚 wăn

時 shí

戟 shèng

晴 qíng

Radical: 山

哦 é

崩 bēng

岶 gǒu

崧 sōng

菔 jí

崎 qí

崢 zhēng

to meet face to face
stars, planets
to dry in the sun
yesterday
late, night
time, season
light
fine, clear sky

忘

悟

忙

憬

悝

悵

怒

情

恫

憚

惦

怕

high, steep

to collapse

a hill in Hunan

a peak in Henan

precarious

rugged, rough

steep, towering
字 zì a character

安 ản calm, quiet

容 róng to contain

官 guan officer

完 wán to complete

家 jiā household, family

Radical: 心

亡 wàng to forget

wù to come to realize

máng busy

jing awaken

lí to pity, sad

chàng disappointed

nù furious

qíng emotions

tóng moaning with pain

dàn to shrink from

diàn to think about

pà to fear

憒 kùi confused, dazed

忠 zhöng loyal, faithful

恃 shì be contemptuous

慢 màn slow

忍 rěn to bear, endure 


\section{Procedures:}

I. To review characters containing radicals, 刀土人口 女 Characters are reviewed following step II. 2--3

II. Teach characters containing the following radicals: 人日山穴

1. Review the pronunciation and the meaning of the radicals.

2. The teacher says one character in its English definition, and let students say which radical the character contains. For example, the teacher says " star", and the students answer " the character has the radical $\mathrm{日}$ (sun, planet)."

3. Then students find the character that has the meaning "star", and pronounce the character.

4. This keeps going until students are familar with the radicals, and can make their judgement quickly and accurately. 


\section{LESSON PLAN C-7}

Class: First-year Chinese class at the university.

Time: 25 minutes

Teaching Objective: To review characters containing radicals, 刀土人口女日

$$
\text { 山穴心 }
$$

To teach characters containing radicals, 手玉犬火水.

Teaching Materials: Lesson 3 in the Control Group Character Packet. Transparency of Lesson 3.

Lesson 3

\begin{tabular}{|c|c|c|c|c|c|}
\hline \multicolumn{2}{|c|}{ Radical: 手 } & & \multicolumn{2}{|c|}{ radical: 犬 } & \multirow[b]{2}{*}{ ruthless } \\
\hline 捻 & niăn & to twist with fingers & 狠 & hĕn & \\
\hline 摑 & gúo & to slap & 猩 & xỉng & chimp \\
\hline 按 & àn & to press & 狸 & lí & fox \\
\hline 扶 & fú & to support with hand & 猙 & zhëng & ferocious \\
\hline 挽 & wăn & to roll up & 猿 & yuán & ape \\
\hline 探 & căi & to pick & 狗 & gơu & dog \\
\hline 汼 & bàn & to stir & & & \\
\hline 撣 & dăn & to dust & \multicolumn{2}{|c|}{ radical: 火 } & \\
\hline 掂 & diän & to weigh in hand & 焦 & jiäo & scorched \\
\hline 拎 & ling & to lift & 燈 & dëng & light, lamp \\
\hline 拱 & gǒng & to cup one hand in & 炒 & chăo & to fry \\
\hline & & the other in greeting & 炸 & zhà & to deep fry \\
\hline 抱 & bào & to embrace & 烷 & wán & alkane $(\mathrm{Ch}$ \\
\hline 扳 & bän & to pull, twist & 炮 & pà & fire cracke \\
\hline 搾 & zhà & to press, extract & \multirow{2}{*}{\multicolumn{2}{|c|}{ shú }} & ripe, coo \\
\hline 攬 & lăn & to bring to one's side & & & \\
\hline & & & \multicolumn{2}{|c|}{ Radical: 水 } & \\
\hline \multicolumn{2}{|c|}{ Radical: $玉$} & & 涼 & liáng & cool \\
\hline 瑪 & mă & agate & 溜 & liū & slip away \\
\hline 珂 & $\mathrm{ké}$ & inferior kind of jade & 漪 & $\mathrm{yì}^{-}$ & ripples \\
\hline 理 & lĭ & structure of material & 河 & hé & river \\
\hline 琯 & guăn & stone tube & 淨 & jìng & clean \\
\hline 環 & huán & ring, bracelet & 汰 & tài & wash out \\
\hline 璜 & huáng & jade (semi-circular) & 溶 & róng & to melt \\
\hline 玷 & diàn & a flaw in jade & 沙 & shä & sand \\
\hline 珀 & po & amber & 洞 & dòng & hole \\
\hline 玲 & ling & tinkling of jade & 洄 & húi & whirlpool \\
\hline 珠 & zhū & pearl, beads & 灆 & làn & to flood \\
\hline
\end{tabular}




\section{Procedures:}

I. Review characters containing radicals, 刀土人 $\square$ 女日山灾 Characters are reviewed following step II. 2--3

II. Teach characters containing the following radicals: 手玉犬火水.

1. Review the pronunciation and the meaning of the radicals.

2. The teacher says one character in its English definition, and let students say which radical the character contains. For example, the teacher says "amber". and the students answer " the character has the radical 玉 (jade)."

3. Then students find the character that has the meaning "amber", and pronounce the character.

4. This keeps going until students are familar with the radicals, and can make their judgement quickly and accurately. 


\section{LESSON PLAN C-8}

Class: First-year Chinese class at the university.

Time: 25 minutes

Teaching Objective: To review characters containing radicals, 刀土人口女日 山穴玉犬火水.

To teach characters containing radicals, 水木.

Teaching Materials: Lesson 4 in the Control Group Character Packet. Transparency of Lesson 4.

Lesson 4

Radical: 水

漂 piāo

泊 bó

沅 yuán

浣 wăn

泮 pàn

淇 qí

淞 sōng

漓 lí

淶 lái

泡 pào

汕 shàn

漫 màn

to float

lake

name of a river

to wash

pool

name of a river

name of a river

柞

果

zùo

gǔo

棵 kē

桐 tóng

標 biāo

柏 bó

栱 gǒng

櫃 gùi

water dripping

板

name of a river

băn

lí

to soak

梨

basket for catching

樵

fish

to overflow

棋

松

榨

qiáo

qí

sōng

zhà

Radical: 木

梧 wú

榪 mà

機 ji

榴 liú

本 běn

椅 yi

柯 $\mathrm{ke}$

梩 lǐ

校 jiào

桎 zhì

枯 ku

橙 chéng

枌 fén

Chinese parasol tree

枋 fāng head-board of a bed machine pomegranate

梅 méi

a type of oak

fruits measure word phoenix tree mark, sign cypress post, pillar cabinet board, plank pear woodcutter chess pine to extract by pressing tree used for boats plum, prune 榕 róng bastard banian measure word chair axe-handle basket to proofread hand cuffs dried up, withered orange elm with white bark 


\section{Procedures:}

I. Review characters containing radicals, 刀土人口女日山穴手玉火水. Characters are reviewed following step II. 2--3

II. Teach characters containing the following radicals: 水木.

1. Review the pronunciation and the meaning of the radicals.

2. The teacher says one character in its English definition, and let students say which radical the character contains. For example, the teacher says " pear", and the students answer " the character has the radical 木 (tree)".

3. Then students find the character that has the meaning "pear", and pronounce the character.

4. This keeps going until students are familar with the radicals, and can make their judgement quickly and accurately. 


\section{LESSON PLAN C-9}

Class: First-year Chinese class at the university.

Time: 25 minutes

Teaching Objective: To review characters containing radicals, 刀土人 $\square$ 女日 山穴心手玉犬火水木.

To teach characters containing radicals, 竹委示目庐。

Teaching Materials: Lesson 5 in the Control Group Character Packet. Transparency of Lesson 5.

\section{Lesson 5}

Radical: 竹

笨 bèn

笳 jiā

笆 bä

䇺 deng

筝 zhēng

笭 jí

筒 tóng

管 guăn

籃 lán

簿 bó

籬 lí

筒 gơ

Radical: 禾

稔 niăn

稞 $\mathrm{ke}$

稻 dà

秀 xiù

秋 qiū

種 zhòng

獲 hùo

Radical: 示

禡 mà

柌 cí

新 qí

禪 chán

裙 zuio

祺 qí stupid, dull

reed leaf whistle

fence

large umbrella

stringed instrument

book box

tube-shape object

pipe, flute

basket

bamboo tray, foil

fence

basket trap for fish

ripe grain

grain for grinding

rice

beautiful

autumn

to plant

to harvest

sacrifice to the god ancestral shrine spirit of the earth to worship nature fortune of a nation fortunate, luck
Radical:

盲 máng blind

盯 ding to keep an eye on

睜 zhëng to open eyes wide

瞪 dèng to stare

礁 qiáo to look, to see

睞 laì to look at

睛 jing pupils

眼 yăn eyes

Radical: :ं

痕 hén mark, trace

溜 liú tumor

疔 ding malignant boil

痣 zhì mole

疤 bā scar

哓 shā heatstroke

痄 zhà swellings, sores

㿋 dàn wearied

痁 diàn malarial fever

瘭 piāo whitlow

瘜 xí polypus

庖 páo pimple

瘈 zhî hemorrhoids

瓷 tóng moaning with pain 


\section{Procedures:}

I. Review characters containing radicals, 刀土人口女日山方手玉犬火水木. Characters are reviewed following step II. 2--3

II. Teach characters containing the following radicals: 竹禾示目庐.

1. Review the pronunciation and the meaning of the radicals.

2. The teacher says one character in its English definition, and let students say which radical the character contains. For example, the teacher says " scar",

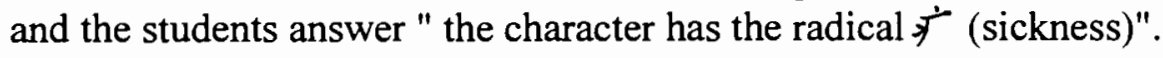

3. Then students find the character that has the meaning "scar", and pronounce the character.

4. This keeps going until students are familar with the radicals, and can make their judgement quickly and accurately. 


\section{LESSON PLAN C-10}

Class: First-year Chinese class at the university.

Time: 25 minutes

Teaching Objective: To review characters containing radicals, 刀土人口 女日 山穴手玉火水木竹禾示目庐.

To teach characters containing radicals, 岖虫肉.

Teaching Materials: Lesson 6 in the Control Group Character Packet. Transparency of Lesson 6.

Lesson 6

\begin{tabular}{|c|c|c|c|c|}
\hline \multicolumn{2}{|l|}{ Radical: 帅 } & \multicolumn{3}{|c|}{ Radical: 虫 } \\
\hline 茗 míng & tender tea leaves & 螞 & má & ants \\
\hline fú & hibiscus & 閾 & gúo & cricket \\
\hline róng & hibiscus & 蟣 & jī & louse, aphis \\
\hline$k \bar{e}$ & severe & 蚛 & fú & water beetle \\
\hline hé & water lily & 蚊 & wén & mosquito \\
\hline jiāo & aquatic grass & 蛟 & jiāo & dragon \\
\hline $\mathrm{g} \overline{\mathrm{u}}$ & mushroom & 蚱 & zhà & grass hopper \\
\hline kǔ & bitter & 蜔 & húi & round worm, \\
\hline bà & plantain banana & & & ascarid \\
\hline fén & sweet smell & 螾 & huáng & horse leech \\
\hline jiù & old & 螗 & táng & a kind of cicada \\
\hline shä & $\begin{array}{l}\text { sage used for } \\
\text { raincoat }\end{array}$ & 蜻 & qïng & dragonfly \\
\hline lan & blue & & ll: 肉 & \\
\hline cài & vegetable & 腥 & xing & raw meat, \\
\hline piáo & duck-weed & & & bad smell \\
\hline ling & fungus & 胺 & ān & amine \\
\hline gäi & roots of plants & 肛 & gāng & the anus \\
\hline pín & apple & 脹 & zhàng & to feel bloated \\
\hline 莉 & white jasmine & 腹 & fu' & abdomen \\
\hline mei & berry & 腰 & yāo & waist \\
\hline jiāo & banana & 肪 & fáng & fat \\
\hline $\mathrm{ji} / \mathrm{q} 1$ & wovwn grass & 胞 & bāo & cell \\
\hline 蘺 & grass, weed & 肕 & rèn & tough, hard \\
\hline lai & wild herbs & 胙 & zùo & flesh offered to \\
\hline bāo & bud & & & ancestors \\
\hline fän & tomato & 膘 & piāo & fat swollen horse \\
\hline
\end{tabular}




\section{Procedures:}

I. Review characters containing radicals, 刀土人口女日山苸玉犬火水 木竹禾示目广。

Characters are reviewed following step II. 2--3

II. Teach characters containing the following radicals: 忺虫肉.

1. Review the pronunciation and the meaning of the radicals.

2. The teacher says one character in its English definition, and let students say which radical the character contains. For example, the teacher says "cricket", and the students answer " the character has the radical 虫 (insect)".

3. Then students find the character that has the meaning "cricket", and pronounce the character.

4. This keeps going until students are familar with the radicals, and can make their judgement quickly and accurately. 


\section{LESSON PLAN C-11}

Class: First-year Chinese class at the university.

Time: 25 minutes

Teaching Objective: To review characters containing radicals, 刀土人 $\square$ 女日

$$
\text { 山的心手玉犬火水木竹禾示目产岖虫肉. }
$$

To teach characters containing radicals, 糸衣食交.

Teaching Materials: Lesson 7 in the Control Group Character Packet. Transparency of Lesson 7.

Lesson 7

Radical: 系

縵 man

silk thread

糿 rèn

紊 wèn

to sew

disorderly

紡 făng

縭 lí

繃 bëng

綺 q1

紋 wén

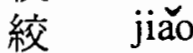

緻 zhi

紛 fen

紗 shä

繯 huán

纜 lăn

綵 căi

縹 piăo

絆 bàn

繹望

繙 fān

級 jí

綱 gäng

紙 zhí

紅 hóng

毉 yì

spin, thin silk cloth bridal ornament

to tie, bind

figured woven silk

lines

hanging

soft, delicate

tangled, confused

yarn, gauze

fine silk

thick rope, cable

coloured

misty

cause to stumble, trip

袈 $\quad \mathrm{jia}$

outer vestment worn

by Buddist monk

裟 shā outer vestment worn

by Buddist monk

袍 páo robe, gown

褙 bèi cloth or paper pasted

together

裏 lǐ lining, inside

装 qiú fur coat

Radical: 食

飼 sì to feed

饑 ji hunger

餃 jiǎo

餜 gŭo

stuffed dumplings

biscuits, pastry

飯 fàn meal

飽 bǎo full

饅 mán steamed bun

to unravel

to interprete

level, rank, step

館

guăn hall of exhibition

Radical: 主

main rope of a net

遛 liù to linger, dawdle

paper

red

迴

húi

to wind, circle

alas, signing sound

還

huán to return, turn

返 făn to return

遠 yuăn far

Radical: 衣

$\begin{array}{lll}\text { 裡 } & \text { lí } & \text { lining, inside } \\ \text { 複 } & \text { fừ } & \text { to repeat } \\ \text { 襤 } & \text { lán } & \text { shabby, ragged }\end{array}$

used in translating "ka"-sanscrit sound 


\section{Procedures:}

I. Review characters containing radicals, 刀土人口女日山它玉 木竹禾示目应虫虫肉.

Characters are reviewed following step II. 2--3

II. Teach characters containing the following radicals: 系衣食文.

1. Review the pronunciation and the meaning of the radicals.

2. The teacher says one character in its English definition, and let students say which radical the character contains. For example, the teacher says "fur coat", and the students answer " the character has the radical 衣 (clothing)".

3. Then students find the character that has the meaning "fur coat", and pronounce the character.

4. This keeps going until students are familar with the radicals, and can make their judgement quickly and accurately. 


\section{LESSON PLAN C-12}

Class: First-year Chinese class at the university.

Time: 25 minutes

Teaching Objective: To review characters containing radicals, 刀土人口女日

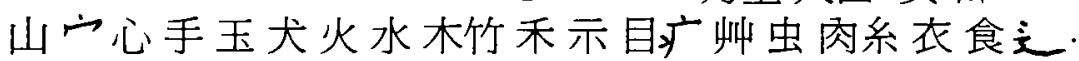
To teach characters containing radicals, 言金車.

Teaching Materials: Lesson 8 in the Control Group Character Packet. Transparency of Lesson 8.

\section{Lesson 8}

Radical: 言

語 yư

詞 cí

譏 jī

諒 liàng

訂 dìng

訶 he

詁 gú

詐 zhà

課 kè

誌 zhì

諺 yàn

該 gai

訟 sòng

誠 chéng

訪 făng

請 quing

譯 yì

謾 mán

認 rèn

訕 shàn

詩 $\operatorname{shī}$

Radical: 車

軻 $\mathrm{ke}$ ，

轅 yuán language

words, term

to mock

to forgive

to book, subscribe

to scold

explinations of

ancient words

to deceive, cheat

lessson

magazine, records

saying

should

law suit

honest

to visit

request (please)

to translate

to insult

to admit, recognize

to ridicule, slander

poetry
輪 lún

軔 rèn

輛 liàng

較 jiào

輸 shū

Radical: 金

釦 kò

銘 míng

鋼 gāng

錡 qi

釘 ding

錮 gù

䤧 bā

鋝

鈦

鎔

鈔

錄

鍊

鍊

銅 wheel to skid wheel to stop measure word for cars to compete to lose

bottons engraved inscription steel pot or pan with feet nail, to nail to hold in custody palladium (Chem.) clank, clang titanium to fuse metals paper money to record to forge, chain copper

a pair of wheels

shaft of a cart 
Procedures:

I. Review characters containing radicals, 刀土人口女日山金玉犬火水 木竹广示目定虫虫肉系衣食禾。

Characters are reviewed following step II. 2--3

II. Teach characters containing the following radicals: 言金車.

1. Review the pronunciation and the meaning of the radicals.

2. The teacher says one character in its English definition, and let students say which radical the character contains. For example, the teacher says "copper". and the students answer " the character has the radical 金 (metal)".

3. Then students find the character that has the meaning "copper ", and pronounce the character.

4. This keeps going until students are familar with the radicals, and can make their judgement quickly and accurately. 


\section{LESSON PLAN C-13}

Class: First-year Chinese class at the university.

Time: 25 minutes

Teaching Objective: To review characters containing radicals, 刀土人口 女日 山穴手玉犬火水木竹禾示目产州虫肉系 衣食妾言金車.

To teach characters containing radicals, 馬魚鳥石口.

Teaching Materials: Lesson 9 in the Control Group Character Packet. Transparency of Lesson 9.

\section{Lesson 9}

Radical: 魚

鯨 jing

鯉 lǐ

鮫 jiāo

鯊 shā

鱑 huáng

鰾 biào

鰣 shí

鯠 lái

鮑 bào

鰻 mán

鮁 wěi

魟 gōng

Radical: 鳥

鵬 péng

鴣 $\mathrm{gu}$

鳩 jiü

鸝 lí

䳡 jiāo

鶹 liú

Radical: 石

磯 ji

砥 zhĩ / dĩ whale

carp

shark

shark

sturgeon

bladder of fish

a fish enters the river

in May and returns

in September

a kind of eel

abalone

eel

tuna

flying fish

huge fabulous bird

partridge

turtledove

oriole

small bird, tit

large horned-owl

breakwater, jetty

to polish, rock
嗍 péng sodium borate

砂 shā sand

碌 lù mediocre

磺 huáng sulphur

礁 jiäo submerged rocks

碁 qí game of chess

砲 pào cannon, fire cracker

磴 deng steps on rock

Radical:

嗎 ma interrogative particle

吾 wú I, me

念 niàn to read

哪 nă which

吧 $b \bar{a}$ final particle

呵 hē breath out, to scold

叮 ding to sting

咕 gu onomatopoeia

咳 ké to cough

吩 fen to instruct

喓 yāo chirping of grass

hopper

咆 páo roar

吵 chăo noisy

吻 wěn to kiss 
Radical: 馬

\begin{tabular}{|c|c|c|}
\hline 騎 & qí & to ride \\
\hline 駕 & jià & to drive, ride \\
\hline 駑 & nú & inferior horse \\
\hline 䲱麗 & lí & good black horse \\
\hline 騏 & qí & spotted horse \\
\hline 騮 & liú & $\begin{array}{l}\text { bay horse with a } \\
\text { black mane }\end{array}$ \\
\hline & xún & to domesticate, tame \\
\hline & jing & to terrify, frighten \\
\hline
\end{tabular}

\section{Procedures}

I. Review characters containing radicals, 刀土人口女日山穴手玉犬火水 木竹禾示目疗㞲虫肉系衣食主言金車.

Characters are reviewed following step II. 2--3

II. Teach characters containing the following radicals: 馬魚鳥石口.

1. Review the pronunciation and the meaning of the radicals.

2. The teacher says one character in its English definition, and let students say which radical the character contains. For example, the teacher says "eel", and the students answer " the character has the radical 魚 (fish)".

3. Then students find the character that has the meaning "eel", and pronounce the character.

4. This keeps going until students are familar with the radicals, and can make their judgement quickly and accurately. 


\section{LESSON PLAN C-14}

Class: First-year Chinese class at the university.

Time: 30 minutes

Teaching Objective: To review characters containing radicals, 刀土人口女日 山穴手玉犬火水木竹禾示目庐岖虫肉系 衣食主言金車馬魚鳥石口。

To teach characters containing radicals, 足齒牛来走生巾 西革力貝大方欠雨文.

Teaching Materials: Lesson 10 in the Control Group Character Packet.

Lesson 10

Radical: 足

踩 căi to step on

蹬 dèng to step

跟 gen to follow, heel

跌 fú sit cross-legged

踃 bèng to jump, bounce

跤 jiāo to wrestle

跑 păo to run

蹯 fán paws of an animal

跼 jú to bend down

Radical: 女

歌 yǔ musical instrument

攻 gong to attack

效 xiào to imitate

政 zhèng politics

故 gù reason, cause

放 fang to loosen, to let go

Radical: 齒

龉 yŭ irregular teeth

齡 líng front teeth, age

Radical: 牛

牸 zì female cow

牲 shēng cattle

牯 gú male cow, a bull
Radical: 未

耗 $\mathrm{zi}^{-}$hoe up the earth

耙 bà/ pá rake; to plow

Radical: 生

甥 shēng children of sisters

Radical: 巾

幗 gúo cap worn by women

帳 zhàng a tent

帽 mào hat

幡 fán a banner

幔 màn a curtain, screen

Radical: 西

酶 zuò/cù vinegar

酩 míng

酊 ding

酤 gù

醫 $\quad \mathrm{y} \overline{1}$

醮 jido

醨 lí

strong liquor intoxicated, drunk

to deal in spirit

to cure, a doctor

to sacrifice

dregs of wine

Radical: 革

鞍 an saddle

靶 bă target 
Radical: 走 $\begin{array}{ll} & \text { Radical: 大 } \\ \text { to pursue } & \text { 奔 ben to run away }\end{array}$

Radical: 貝

貢 gòng

to offer as

Radical: 欠

賬 zhàng tribute

賅 gäi

a bill

販 fàn

to give

歌 $\mathrm{yi}$

欺 qi

Alas! Ah!

賕 qiú

to trade, sell

to bribe

Radical: 雨

雯 wén colouring of clouds

雨 báo hail

Radical: 方

旖 $\mathrm{y}^{\overline{1}}$

waving

施 máo

旛 fan

gracefully
banner
a funeral banner

Radical: 力

功 gông merit, good results

努 nŭ to strive

to cheat

\section{Procedures:}

I. Review characters containing radicals, 刀土人口女日山穴王犬火水广 木竹禾示目岖虫肉系衣食立言金車馬魚鳥石口.

Characters are reviewed following step II. 2--3

II. Teach characters containing the following radicals: 足齒牛走生巾西鞂 力貝大方欠雨.

1. Introduce the pronunciation and the meaning of the radicals.

2. The teacher says one character in its English definition, and let students say which radical the character contains. For example, the teacher says "irregular teeth", and the students answer " the character has the radical 齒 (teeth)".

3. Then students find the character that has the meaning "irregular teeth", and pronounce the character.

4. This keeps going until students are familar with the radicals, and can make their judgement quickly and accurately. 


\section{LESSON PLAN C-15}

Class: First-year Chinese class at the university.

Time: 30 minutes

Teaching Objective: To review characters containing radicals, 刀土人口女日 山它手玉火水竹禾示目庐㞲虫肉系 衣食主言金車馬魚鳥石口足齒牛来走生巾 西革力貝大方欠雨.

To teach characters containing radicals, 田鬼邑乃白穴骨髟 羊父爪几气犽鼠米戶青.厂.

Teaching Materials: Lesson 11 in the Control Group Character Packet.

Lesson 11

Radical: $\boxplus$

町 ding path between fields

畔 pàn a path dividing fields

Radical: 鬼

魍 liăng ghost

Radical: 厂

厘 lí the thousandth part of a Chinese foot

Radical: 邑

郊 jiāo outer suburb

到 zhì flourishing

鄧 dèng a last name

鄲 dān name of a place

麗 lî name of a place

Radical: $\beta$

阼 zùo

陔 gäi a grade, ledge

阪 băn slope, hillside

防 fáng to guard
Radical: 穴

$\begin{array}{lll}\text { 窒 } & \text { zhì } & \text { to suffocate } \\ \text { 窠 } & k \bar{e} & \text { a hole, nest }\end{array}$

Radical: 骨

骷 kủ skeleton

髁 kě thigh-bone

骸 hái bones of the body

Radical: 髟

髦 máo excellent, popular

慧 huán to dress hair in a

knot

瀃 sōng to loose, to let go

Radical: 羊

羚 líng antelope

Radical: 父

爸 bà father

Radical: $\pi$

爬 pá to crawl, creep

Radical: 几

筧 dèng stool 
Radical: 白

皎 jiäo

Radical:

氛 fén

atmosphere

氦 hài

Radical: 呵

吩 fén

邻 líng

翻 fän

Radical: 鼠

鼠分 fěn bright

vapour,

helium, gas

to fly

a feather

to upset, to open
Radical: 米

糖 tang

精 jing

sugar, candy

the essence, fine

Radical: 戶

房 fáng house, room

Radical: 青

靚 jìng

to paint the face

\section{Procedures:}

I. Review characters containing radicals, 刀土人口女日山穴手玉犬火水 木竹禾示目庐屾虫肉系衣食文言金車馬魚鳥石口.足齒牛未 走生巾西革力貝大方欠雨父.

Characters are reviewed following step II. 2--3

II. Teach characters containing the following radicals, 田鬼厂邑队白穴骨钐羊 父爪几气犽鼠米戶青.

1. Introduce the pronunciation and the meaning of the radicals.

2. The teacher says one character in its English definition, and let students say which radical the character contains. For example, the teacher says "skeleton", and the students answer " the character has the radical 骨 (bones)".

3. Then students find the character that has the meaning "skeleton", and pronounce the character.

4. This keeps going until students are familar with the radicals, and can make their judgement quickly and accurately. 


\section{LESSON PLAN C-16}

Class: First-year Chinese class at the university.

Time: 30 minutes

Teaching Objective: To review characters containing radicals, 刀土人口女日 山手玉犬火水木竹禾示目帅虫肉系

衣食之言金車馬魚鳥石口足齒牛来走生巾

西革力貝大方欠雨·田鬼厂邑队白穴骨髟羊

父爪几气狗鼠米戶青.

To teach characters containing radicals, 爪子弓徆香頁門

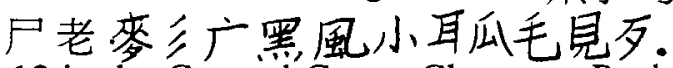

Teaching Materials: Lesson 12 in the Control Group Character Packet.

Lesson 12

Radical: 爪

爭 zhëng

Radical: 子

拏 nú

孩 hái

Radical: 弓

驽 nu

彈 dàn

Radical: 彳

復 fừ

徊 húi

彷 făng

徠 lài

Radical: 西

覆 fù

Radical: 香

旙 fù

Radical: 瓜

漂 piáo to fight for

children

children

cross bow

bullet, a shot

to return, repeat

undecided

similar to

to induce to come

to overturn, cover

strong fragrance

\begin{tabular}{lll} 
& \multicolumn{2}{l}{ Radical: 广 } \\
& 店 diàn \\
ladle made of gourd & 庖 páo
\end{tabular}

the chin

to praise

Radical: 閒

闠 huan a gate

Radical: $\rightleftharpoons$

局 jú position

Radical: 老

考 gou old

Radical: 石

酕 dăn entirely, utmost

Radical: 見

覽 lăn to look at

Radical: 來

麥黄 huáng barley

Radical: $广$

a kitchen 
Radical: 頁

顆 kê

顏 yán

領 líng

Radical: 風

飄 piâo

Radical: 小

少 shăo

Radical: 耳

聆 líng

Radical: 毛

㲖 mào

踏 qiú

Radical: 舟

舲 líng

舫 făng

艋 shàn
Radical: 黑

點 diăn a dot, spot

small round things

colors

to lead, a collar

to whirl, flutter

little, few

Radical: 片

版 băn blocks for printing

Radical: 鹿

麒 qí fabulous animal, body of a deer.

Radical: 皿

盛 shèng abundant

chéng to hold, fill

a globe, knob

Radical: 隹

離 li ${ }^{\prime}$ to leave

雊 gou the crowing of a pheasant

\section{Procedures:}

I. Review characters containing radicals, 刀土人口女日山穴心手玉火火水 木竹禾示目庐岖虫肉系衣食文言金車馬魚鳥石口.足齒牛来走

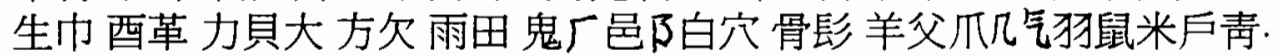
Characters are reviewed following step II. 2--3

II. Teach characters containing the following radicals, 爪子弓徆香頁門尸老…

1. Introduce the pronunciation and the meaning of the radicals.

2. The teacher says one character in its English definition, and let students say which radical the character contains. For example, the teacher says "strong fragrance", and the students answer " the character has the radical 香 (fragrance)".

3. Then students find the character that has the meaning "fragrance", and pronounce the character.

4. This keeps going until students are familar with the radicals, and can make their judgement quickly and accurately. 
APPENDIX G

CURRICULUM (EXPERIMENTAL GROUP) 
Schedule for the Experimental Group

1. First class: Introduction of Radicals (Based on Mathews' Chinese English Dictionary)

2. Introduction of 12 commonly seen radicals.

3. Introduction of 12 more commonly seen radicals.

4. Introduction of 11 more commonly seen radicals.

5. 14 phonetic ștems and their rules.

6. 14 phonetic stems and their rules.

7. 10 phonetic stems and their rules.

8. 11 phonetic stems and their rules.

9. 13 phonetic stems and their rules.

10. 12 phonetic stems and their rules.

11. 11 phonetic stems and their rules.

12. 8 phonetic stems and their rules.

13. More radicals: 16 less commonly seen radicals.

14. More radicals: 18 less commonly seen radicals.

15. More radicals: 26 less commonly seen radicals.

16. Review of all phonetic stems.

Mathews, R.H. (1943). Mathews' Chinese English Dictionary. Cambridge: Harvard University Press. 


\section{LESSON PLAN E-1}

Class: First-year Chinese class at the university.

Time: 25 minutes.

Teaching Objective: To teach students how to identify the position of radicals.

Teaching Materials: Handouts of ways of finding radicals.

\section{Handout:}

* The Radical is from the list of $\mathbf{2 1 4}$ Radicals, the Phonetic is the other half of the character. The Phonetic can sometimes be another Radical itself, as in 近記理罵

* The Radical should give a clue to the meaning of a character o

* A good deal of difficulty will be found in knowing under what radical to look for any particular character. The radical may occupy any part of the character.

It may be at the top, as 竹 in 管 or at the bottom, as $\mathrm{mI}$ in 監 on the left, as 系 in 給 on the right, as 邑 in 都 surrounding it, as $\square$ in 固 or in the middle of it, as $\square$ in 周 partially surrounding it, as 度 in 痕 or the radical may be split in two, enclosing the phonetic, as 衣 in 裏 Sometimes it is mixed up with the phonetic, as $\rceil$ in 再

\section{How to find the Radical:}

1. First you have to consider whether the character is a radical itself. Thus 音香高 辛玉 are themselves radicals.

2. If the character is not a radical the next step is to break it into two parts. In two cases out of three there will be one part on the right hand and another on the left such as 他理江. Or the division may be horizontal, one half being above, the other beneath, and in this case the division is not quite so simple as in 告 答罪靈. Or one half may enclose the other on two or more sides, as 有反道 
3. If one of the two parts is a radical and the other is not, obviously we must look for it under that part which is a radical; as, 白金心 which come from 的釘忽 respectively, the other halves not being radicals.

4. If both halves of a character are radicals, the following rules may be applied:

a. If the character consists of a right-hand and a left-hand half, The left-hand half is usually the radical; as, for instance, 信加快如律性拉明根

!!!Exceptions: The radicals 刀力文斤欠邑佳鳥没are generally found on the right side of the character, but they are often the radical.

*The rule that the left-hand portion of the character is the radical also holds in cases where the radical extends to two or more sides of the character 庫建房連.

b. If the character consists of an upper and lower half, both being radicals, the lower half is usually the radical. As, for instance, 思昏季果泉冬

1!!Exceptions: The following radical are placed at the top of the character , and they are the radicals: 忺竹穴四 雨爪二立。

* These rules will dispose of $95 \%$ of the characters. 


\section{LESSON PLAN E-2}

Class: First-year Chinese class at the university.

Time: 25 minutes

Teaching Objective: To teach 12 radicals and provide examples.

Teaching Materials: Blackboard.

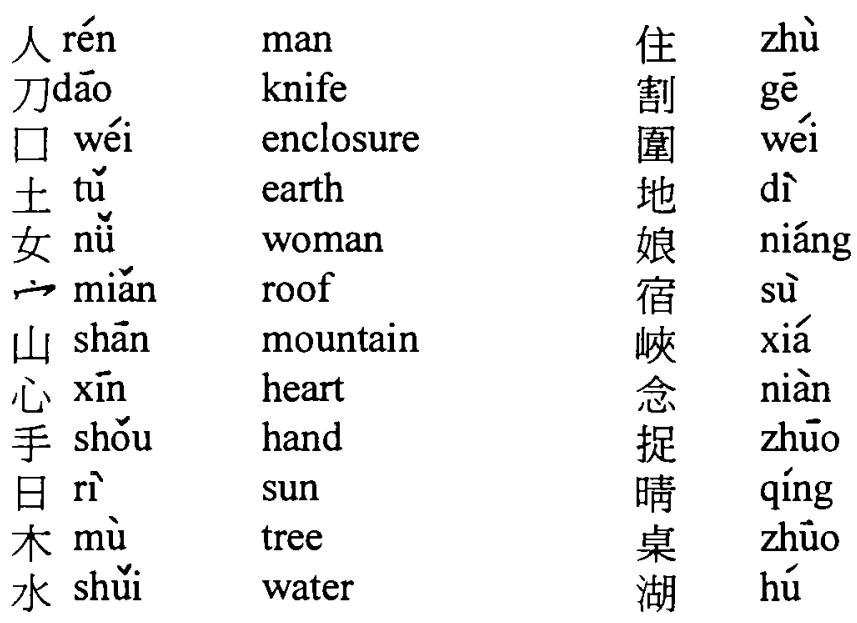

\section{Procedures:}

I. Show students how radicals represent real objects, draw pictures on the board.

II. Practice pronouncing radicals, and give the meaning.

III. Provide with examples containing the radicals, and point out where they locate in each character. 


\section{LESSON PLAN E-3}

Class: First-year Chinese class at the university.

Time: 25 minutes

Teaching Objective: To review 12 radicals in the first lesson.

To teach 12 more radicals and provide examples.

Teaching Materials: Blackboard and the following 12 radicals with their examples.

\begin{tabular}{|c|c|c|c|}
\hline 火 hǔo & fire & 煮 & zhŭ \\
\hline 犬 quăn & dog & 獵 & liè \\
\hline 玉 yù & jade & 珠 & zhū \\
\hline F chúang & disease & 痛 & tong \\
\hline 目 mù & eye & 睡 & shüi \\
\hline 示 shì & sign & 神 & shén \\
\hline 禾 hé & grain & 種 & zhòng \\
\hline 竹 zhú & bamboo & 筆 & \\
\hline 系 mì & silk & 綁 & bång \\
\hline roù & meat, flesh & 肝 & gān \\
\hline cáo & grass & 芬 & fén \\
\hline hứi & insect & 蟋 & $x i$ \\
\hline
\end{tabular}

\section{Procedures:}

I. Review old radicals:

Write radicals on the board and ask students to identify them, and to say what they represent, until students are familiar with the radicals.

II. Teach new radicals:

1. Show students how radicals represent real objects, draw pictures on the board.

2. Practice pronouncing radicals, and give the meaning.

3. Provide with examples containing the radicals, and point out where they locate in each character. 


\section{LESSON PLAN E-4}

Class: First-year Chinese class at the university.

Time: 25 minutes

Teaching Objective: To review 24 radicals in the previous lessons.

To teach 11 more radicals and provide examples.

Teaching Materials: Blackboard.

$\begin{array}{llll}\text { 衣 yĩ } & \text { clothing } & \text { 裙 } & \text { qún } \\ \text { 言 yán } & \text { speech } & \text { 語 } & \text { yú } \\ \text { 車 chē } & \text { vehicle } & \text { 輪 } & \text { lún } \\ \text { 交 chùo } & \text { halt } & \text { 逃 } & \text { táo } \\ \text { 金 jīn } & \text { metal, gold } & \text { 銀 } & \text { yín } \\ \text { 食 shí } & \text { food } & \text { 飯 } & \text { fán } \\ \text { 馬 má } & \text { horse } & \text { 騎 } & \text { qí } \\ \text { 魚 yú } & \text { fish } & \text { 鮮 } & \text { xiản } \\ \text { 鳥 niǎo } & \text { bird } & \text { 鴕 } & \text { túo } \\ \text { 口 kơu } & \text { mouth } & \text { 喝 } & \text { hẻ } \\ \text { 石 shí } & \text { stone } & \text { 砲 } & \text { paò }\end{array}$

\section{Procedures:}

I. Review old radicals:

Write radicals on the board and ask students to identify them, and to say what they represent, until students are familiar with the radicals.

II. Teach new radicals:

1. Show students how radicals represent real objects, draw pictures on the board.

2. Practice pronouncing radicals, and give the meaning.

3. Provide with examples containing the radicals, and point out where they locate in each character. 


\section{LESSON PLAN E-5}

Class: First-year Chinese class at the university.

Time: 30 minutes

Teaching Objective: To teach characters containing phonetic stems, 亡 馬艮五吾 子 念生司國中名安有.

Teaching Materials: Lesson 1 in the Experimental Group Character Packet.

\section{Lesson 1}

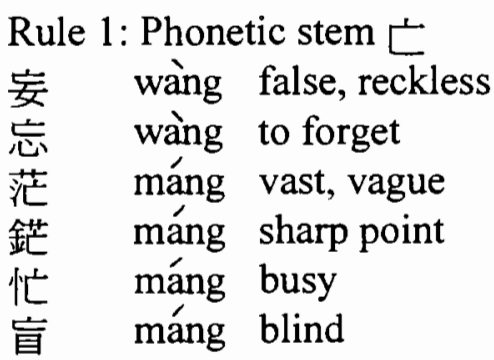

Rule 2: Phonetic stem 馬

嗎 mā interrogative particle

媽 mā mother

瑪 mă agate

螞 má ant

罵 mà to scold

傌 mà to scold

Rule 3: Phonetic stem 艮

根 gēn root, base

跟 gēn heel, to follow

痕 hén scar, trace

很 hěn very

狠 hěn fierce

恨 hèn to hate

Rule 4: Phonetic stem 五

$\begin{array}{lll}\text { 啎 } & \text { wù } & \text { to awake from sleep } \\ \text { 俉 } & \text { wú } & \text { five peopel } \\ \text { 吾 } & \text { wú } & \text { I, me } \\ \text { 悟 } & \text { wù } & \text { to realize } \\ \text { 晤 } & \text { wù } & \text { to see face to face }\end{array}$

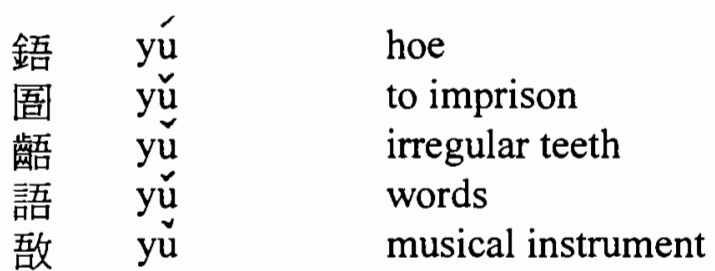

Rule 5: Phonetic stem 子

\begin{tabular}{|c|c|c|}
\hline & & \\
\hline 耔 & $\mathrm{Zi}$ & to hoe up the earth \\
\hline & zì & character \\
\hline 仔 & žr & careful \\
\hline 牸 & zì & female cow \\
\hline \multicolumn{3}{|c|}{ Rule 6: Phonetic stem 念 } \\
\hline 唸 & niàn & to read \\
\hline 捻 & niăn & to take a pinch \\
\hline 稔 & niăn & ripe grain \\
\hline 綕 & niăn & to caulk \\
\hline 趝 & niăn & to pursue, follow \\
\hline
\end{tabular}

Rule 7: Phonetic stem 生

$\begin{array}{lll}\text { 笙 } & \text { shēng } & \begin{array}{l}\text { musical instrument } \\ \text { children of sisters }\end{array} \\ \text { 甥 } & \text { shēng } & \text { surname } \\ \text { 姓 } & \text { xing } & \text { sex } \\ \text { 性 } & \text { xìng } & \text { passionless } \\ \text { 惺 } & \text { xīng } & \text { chimpanzee } \\ \text { 猩 } & \text { xīng } & \text { strong flesh smell } \\ \text { 腥 } & \text { xing } & \end{array}$


Rule 8: Phonetic stem 司

$\begin{array}{lll}\text { 伺 } & \text { sì/cì } & \text { to wait upon } \\ \text { 飼 } & \text { sì } & \text { to feed } \\ \text { 嗣 } & \text { sì } & \text { to inherit } \\ \text { 詞 } & \text { cí } & \text { phrases } \\ \text { 祠 } & \text { cí } & \text { ancestral temple }\end{array}$

Rule 9: Phonetic stem 國

$\begin{array}{lll}\text { 掝 } & \text { gúo } & \text { to slap } \\ \text { 蟈 } & \text { gúo } & \text { cricket, cicada } \\ \text { 掝 } & \text { gúo } & \text { cap worn by women } \\ \text { 㖪 } & \text { gùo } & \text { to chatter }\end{array}$

Rule 10: Phonetic stem 中

$\begin{array}{lll}\text { 忠 zhöng } & \begin{array}{l}\text { loyal, faithful } \\ \text { inner garment, true } \\ \text { 哀 }\end{array} \\ \text { zhöng } & \text { heart } \\ \text { 仲 } & \text { zhòng } & \text { second in order }\end{array}$

Rule 11: Phonetic stem 名

荢 míng tea, tea plant

銘 míng to engrave

酩 míng strong liquor

Rule 12: Phonetic stem 安

胺 àn amine (Chem.)

胺 ān to press

鞍 ān saddle

Rule 13: Phonetic stem 有

直 yòu garden

有 yòu to forgive

鮁 wěi tuna

痏 wěi bruise

洧 wěi name of a river

\section{Procedures:}

(Before teach this lesson, teacher should first teach new radicals in this lesson that have not been learned previously.)

Teach characters containing the following phonetic stems, 亡 馬艮五吾子念生司 國中名安有.

1. Introduce the pronunciation of the phonetic stems, and the possible pronunciation they suggest.

2. The teacher pronounces a character says one character, and let students say which phonetic stem the character contains. For example, the teacher says "hen", and the students answer " the character has the phonetic stem 艮 (gèn)

3. The teacher then says the English definition of the character "to hate", and students answer " hen has the radical 心."

4. Then students find this character in the packet and pronounce it.

5. This keeps going until students are familar with the phonetic stem and the radicals, and can make their judgement quickly and accurately. 


\section{LESSON PLAN E-6}

Class: First-year Chinese class at the university.

Time: 30 minutes

Teaching Objective: To review characters containing phonetic stems, 亡 馬艮五吾 子念生司國中名安有.

To teach characters containing phonetic stems, 幾夫工本京 留朋文丁可兩.

Teaching Materials: Lesson 2 in the Experimental Group Character Packet.

Lesson 2

Rule 1: Phonetic stem 幾

幾 jĭ how much

蟣 ji louse, aphis

嘰 ji

譏 jî

磯 ji

機 ji

饑 ji

Rule 2: Phonetic stem 夫

跌 fú sit cross-legged

蛈 fú water beetle

芙 fú hibiscus

鉄 fū axe

扶 fú to support

Rule 3: Phonetic stem 工

功 gōng merit, good results

貢 gòng to offer as tribute

攻 gōng to attack

訌 hóng internal discord

紅 hóng red

虹 hóng rainbow

Rule 4: Phonetic stem 本

$\begin{array}{lll}\text { 奔 bén } & \text { to run away } \\ \text { 苯 běn } & \text { benzene } \\ \text { 笨 } & \text { bèn } & \text { stupid, dull }\end{array}$

Rule 5: Phonetic stem 京

景 jing view, prospects

諒 liàng to forgive

憬 jĭng to rouse, awaken

璟 jing luster of gems

鯨 jing whale

晾 liàng to dry in sun

涼 liáng cool

Rule 6: Phonetic stem 留

$\begin{array}{lll}\text { 溜 } & \text { liú } & \text { to glide, smooth } \\ \text { 遛 } & \text { liù } & \text { to linger, dawdle } \\ \text { 溜 } & \text { liú } & \text { tumor } \\ \text { 榴 } & \text { liú } & \text { pomegranate } \\ \text { 留 } & \text { liú } & \text { large horned-owl } \\ \text { 騮 } & \text { liú } & \text { baby horse with } \\ & & \text { black mane }\end{array}$

Rule 7: Phonetic stem 岡

剛 gāng hard, enduring

崗 gāng ridge of a hill

綱 gāng large rope of a net

鋼 gäng steel

Rule 8: Phonetic stem 志

誌 zhì magazine, book

痣 zhì mole 
Rule 9: Phonetic stem 奇

\begin{tabular}{|c|c|c|}
\hline 綺 & q 1 L & figured woven silk \\
\hline 錡 & qǐ & pot with feet \\
\hline 騎 & qí & to ride \\
\hline 崎 & qí & rugged, rough \\
\hline 渏 & $\mathrm{y}_{\overline{1}}$ & ripples on water \\
\hline 旖 & $\overrightarrow{\mathrm{y}}$ & gracefully waving \\
\hline 椅 & yí & chair \\
\hline 歌 & yì & Alas! Ah! \\
\hline
\end{tabular}

Rule 10: Phonetic stem 朋

棚 péng shed

硼 péng sodium borate

鵬 péng huge fabulous bird

繃 bēng cloth to carry infants

崩 bēng to fall in ruins

蹦 bèng to jump, bounce

Rule 11: Phonetic stem 文

蚊 wén mosquito

紋 wén lines, figures

雯 wén colouring on clouds

汶 wèn name of a river

紊 wèn tangled, disorder
Rule 12: Phonetic stem 丁

$\begin{array}{lll}\text { 叮 } & \text { ding } & \text { to sting } \\ \text { 盯 } & \text { ding } & \text { to keep an eye on } \\ \text { 町 } & \text { ding } & \text { path between fields } \\ \text { 庁 } & \text { ding } & \text { a boil, sores } \\ \text { 釘 } & \text { ding } & \text { nails, to nail } \\ \text { 仃 } & \text { ding } & \text { tinkling noise } \\ \text { 酊 } & \text { ding } & \text { intoxicated, drunk } \\ \text { 訂 } & \text { ding } & \text { to subscribe, book }\end{array}$

Rule 13: Phonetic stem 可

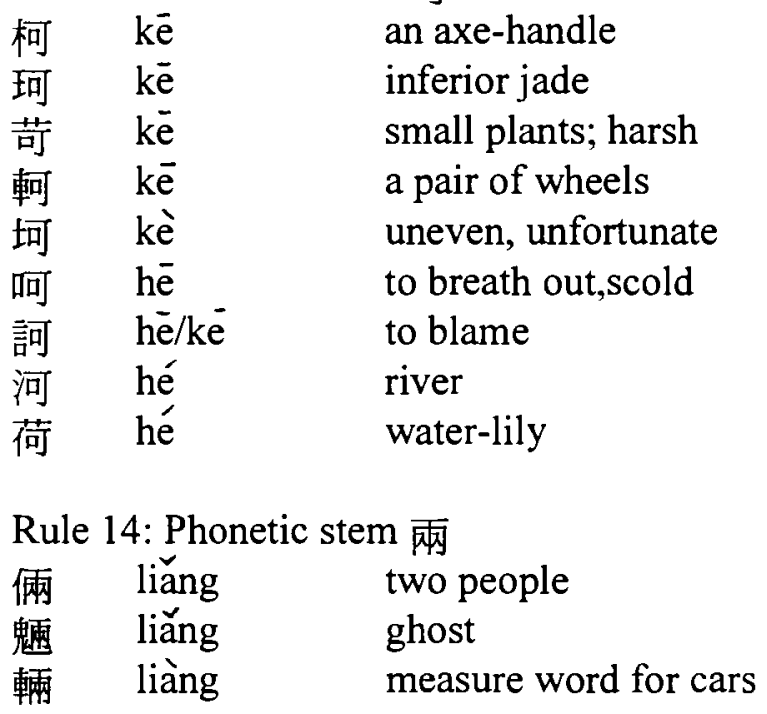

\section{Procedures:}

I. Review characters containing the following phonetic stems, 亡馬艮五吾子 念生 司國中名安有.

Characters are reviewed following step II. 2--4

II. Teach characters containing the following phonetic stems, 幾夫工本京留岡志 奇朋文丁可 兩.

1. Introduce the pronunciation of the phonetic stems, and the possible pronunciation.

2. The teacher pronounces a character says one character, and let students say which phonetic stem the character contains. For example, the teacher says "liu", and the students answer " the character has the phonetic stem 留 (liuu)

3. The teacher then says the English definition of the character "large horned-owl", and students answer "liu has the radical 鶹."

4. Then students find this character in the packet and pronounce it.

5. This keeps going until students are familar with the phonetic stem and the radicals, and can make their judgement quickly and accurately. 


\section{LESSON PLAN E-7}

Class: First-year Chinese class at the university.

Time: 30 minutes

Teaching Objective: To teach characters containing phonetic stems, 亡馬艮五吾 子 念生 司 國 中名安有幾夫工本京留岡志奇朋文丁可 兩.

To teach characters containing phonetic stems, 里交至加長古 毛巴登太.

Teaching Materials: Lesson 3 in the Experimental Group Character Packet.

Lesson 3

Rule 1: Phonetic stem 里

梩 lí a spade

狸 lí

悝 lí

娌 li

理 lì

$\begin{array}{ll}\text { 裡 } & \text { lí } \\ \text { 裏 } & \text { lí } \\ \text { 鯉 } & \text { lí } \\ \text { 厘 } & \text { lí }\end{array}$

Rule 2: Phonetic stem 交

萃 jiāo

校 jiào/xiào

跤 jiāo

效 xiào

郊 jiāo

傚 xiào

鮫 jiäo

姣 jiäo

佼 jiǎo

蛟 jiāo

校 jiāo

鉸 jiǎo

絞 jiǎo

餃 jiăo

較 jiào
Rule 3: Phonetic stem 至

桎 zhì handcuffs

窒 zhî to suffocate

致 zhì to cause, bring out

緻 zhì delicate, soft

蛭 zhì leech

郅 zhì flourishing

侄 zhí unbending, foolish

Rule 4: Phonetic stem 加

the thousandth part 伽 jiā Buddhist term

of a Chinese foot 嘉 jia good, excellent

痂 jiă a scab over a sore

笳 jiā whistle made of reed

袈 jiā dress worn by monks

迦 jiā for transliterating

駕 jià to ride

架 jià frame, rack

outer suburb

to imitate, follow Rule 5: Phonetic stem 長

shark 張 zhäng to open

handsome, pretty 帳 zhàng a tent

handsome, pretty 脹 zhàng a swelled belly

scaly dragon 賬 zhàng a bill

bright, splendid 倀 chäng rash, wildly

to shear, cut out 萇 cháng starfruit

to strangle 悵 chàng disappointed

to compare 
Rule 6: Phonetic stem 古

\begin{tabular}{|c|c|c|}
\hline 估 & gù & to estimete \\
\hline 咕 & gù & to mutter \\
\hline 姑 & gù & aunt, girl \\
\hline 菇 & $\mathrm{gu}$ & mushroom \\
\hline 酟 & gù & to deal in spirit \\
\hline & gú & cobalt \\
\hline & $\mathrm{gu}$ & partridge \\
\hline & gŭ & a bull \\
\hline & gù & firm, strong \\
\hline & gù & reason, cause \\
\hline & gù & chronic disease \\
\hline & gù & to stop, restrain \\
\hline & gǔ & $\begin{array}{l}\text { explanation of words } \\
\text { in ancient books }\end{array}$ \\
\hline & kũ & dried, withered \\
\hline & $\mathrm{ku}$ & skeleton \\
\hline & kǔ & bitter \\
\hline
\end{tabular}

Rule 7: Phonetic stem 毛

施 máo banner

蕼 máo excellent, popular

眊 mào dim-sighted, dull
Rule 8: Phonetic stem 太

$\begin{array}{lll}\text { 汰 tài } & \text { to wash out } \\ \text { 快 tài } & \text { extravagant } \\ \text { 鈦 tài } & \text { titanium }\end{array}$

Rule 9: Phonetic stem 巴

$\begin{array}{lll}\text { 吧 } & \text { bà } & \text { final particle } \\ \text { 疤 } & \text { bā } & \text { scar } \\ \text { 笆 } & \text { bā } & \text { fence } \\ \text { 芭 } & \text { bā } & \text { plantain banana } \\ \text { 耙 } & \text { bà/pá } & \text { rake, to harrow } \\ \text { 鈀 } & \text { bă/pá } & \text { harrow, to harrow } \\ \text { 靶 } & \text { bă } & \text { target } \\ \text { 爸 } & \text { bà } & \text { father } \\ \text { 杷 } & \text { pā } & \text { rake w/out teeth } \\ \text { 爬 } & \text { pá } & \text { to crawl, creep } \\ \text { 琶 } & \text { pá } & \text { Chinese guitar }\end{array}$

Rule 10: Phonetic stem 登

$\begin{array}{lll}\text { 燈 } & \text { dēng } & \text { lamp, light } \\ \text { 簦 } & \text { dèng } & \text { large umbrella } \\ \text { 登 } & \text { dèng } & \text { stool } \\ \text { 瞪 } & \text { dèng } & \text { to stare at } \\ \text { 磴 } & \text { dèng } & \text { stone steps } \\ \text { 蹬 } & \text { dèng } & \text { to step } \\ \text { 鄧 } & \text { dèng } & \text { a last name }\end{array}$

\section{Procedures:}

I. Review characters containing the following phonetic stems, 亡 馬艮五吾子 念生 司 國 中 名安有 幾夫工本京留岡志奇朋文丁可 兩.

Characters are reviewed following step II. 2--4

II. Teach characters containing the following phonetic stems, 里交至加長古毛 巴登太.

1. Introduce the phonetic stems, and the possible pronunciation they suggest.

2. The teacher pronounces a character says one character, and let students say which phonetic stem the character contains. For example, the teacher says " $p a "$, and the students answer " the character has the phonetic stem 巴 $(b \bar{a})$

3. The teacher then says the English definition of the character "large horned-owl", and students answer " pa has the radical $\pi . "$

4. Then students find this character in the packet and pronounce it.

5. This keeps going until students are familar with the phonetic stem and the radicals, and can make their judgement quickly and accurately. 


\section{LESSON PLAN E-8}

Class: First-year Chinese class at the university.

Time: 30 minutes

Teaching Objective: To review characters containing phonetic stems, $\sqsubset$ 馬艮五吾

子念生 司 國 中安有 幾夫工本京留岡志奇朋文

丁可兩里交至加長古毛巴登太.

To teach characters containing phonetic stems, 分乎容奴少

及复录乍免·医。

Teaching Materials: Lesson 4 in the Experimental Group Character Packet.

Lesson 4

Rule 1: Phonetic stem 分

吩 fén to instruct

芬 fen fragrance

氛 fen vapour, atmosphere

紛 fén disorderly, confused

菜 fen a kind of wood

burned for perfume

岎 fén to fly

枌 fén elm with white bark

棼 fén confused, tangled

鿻 fen a kind of mole

粉 fěn powder

份 fèn part, portion

Rule 2: Phonetic stem 爭

崢 zhenng dignified, lofty

猙 zhēng hideous, repulsive

睜 zhēng to open the eyes

筆 zhëng Chinese instrument,

諍 zhēng to caution, debate

鋝 zhēng the clang of metals

Rule 3: Phonetic stem 奴

孥 nú children

駑 nú worn-out old horses

努 nǔ to strive

驽 nú cross bow

$$
\begin{array}{lll}
\text { 砮 nǔ } & \text { flint arrow-heads } \\
\text { 怒 nù } & \text { rage, anger }
\end{array}
$$

Rule 4: Phonetic stem 容

$\begin{array}{lll}\text { 榕 } & \text { róng } & \text { bastard banian } \\ \text { 溶 } & \text { róng } & \text { water melts } \\ \text { 蓉 } & \text { róng } & \text { hibiscus } \\ \text { 鎔 } & \text { róng } & \text { to fuse metals }\end{array}$

Rule 5: Phonetic stem 少

沙 shā sand

莎 shä sage for raincoat

砂 shā sand

沙 shā heatstroke

紗 shā yarn, gauze

裟 shā monks' dress

鯊 shà shark

抄 chāo to copy

鈔 chāo bill

吵 chăo noisy

炒 chăo to fry

Rule 6: Phonetic stem 免

$\begin{array}{lll}\text { 婏 } & \text { miăn/wăn } & \text { to give birth } \\ \text { 勉 } & \text { miăn } & \text { to urge } \\ \text { 冕 } & \text { miăn } & \text { a crown } \\ \text { 晚 } & \text { wăn } & \text { evening } \\ \text { 挽 } & \text { wăn } & \text { to draw, pull }\end{array}$


Rule 6: Phonetic stem 及

\begin{tabular}{|c|c|c|}
\hline 伋 & jí & empty, unreal \\
\hline 岁 & jí & a lofty peak \\
\hline 波 & $\mathrm{ji}$ & $\begin{array}{l}\text { to draw water from a } \\
\text { well }\end{array}$ \\
\hline $\begin{array}{l}\text { 笭 } \\
\text { 級 }\end{array}$ & jí & $\begin{array}{l}\text { a book box } \\
\text { threads arranged in } \\
\text { order, a rank, a step }\end{array}$ \\
\hline
\end{tabular}

Rule 7: Phonetic stem 殹

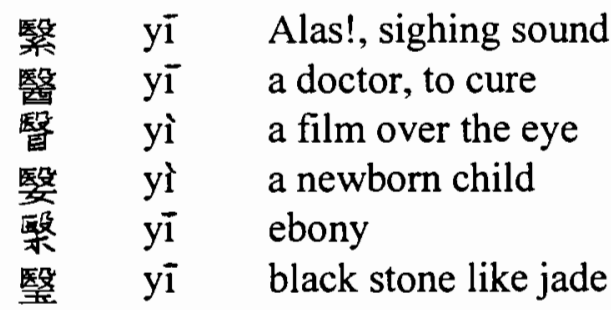

Rule 8: Phonetic stem 复

復 fù to return, repeat

覆 fù to overturn, cover

腹 fù belly

複 fù double, to repeat

橎 fù fragrance
Rule 9: Phonetic stem 彔

錄 lù to record, select

淥 lù name of a river

碌 lù commonplace, rough

祿 lù pay, salary (official)

逐 lù to go carefully

騄 lù name of a horse

Rule 10: Phonetic stem 乍

炸 zhà to fry, to explode

柞 zhà to squeeze, express

痄 zhà swellings and sores

詐 zhà to deceive

虾 zhà grasshopper

搾 zhà to press, extract

阼 zùo the steps leading to the eastern door

昨 zúo yesterday

作 zùo to do, compose

柞 zùo an oak

酢 zùo/cù vinegar

胙 zùo flesh offered to ancestors

\section{Procedures:}

I. Review characters containing the following phonetic stems, 亡馬艮五吾子念生 司國 中名安有 幾夫工本京留岡志奇朋文丁可兩里交至加長古毛巴登太. Characters are reviewed following step II. 2--4

II. Teach characters containing the following phonetic stems, 分爭容奴少及致复 彔乍免.

1. Introduce the pronunciation of the phonetic stems, and the possible pronunciation they suggest.

2. The teacher pronounces a character says one character, and let students say which phonetic stem the character contains. For example, the teacher says "rong", and the students answer "the character has the phonetic stem 容."

3. The teacher then says the English definition of the character "bastard banian", and students answer " rong has the radical 木."

4. Then students find this character in the packet and pronounce it.

5. This keeps going until students are familar with the phonetic stem and the radicals, and can make their judgement quickly and accurately. 


\section{LESSON PLAN E-9}

Class: First-year Chinese class at the university.

Time: 30 minutes

Teaching Objective: To review characters containing phonetic stems, 亡 馬艮五吾 子念生司國中名有 幾夫工本京留岡志奇朋文丁可兩 里交至加長古毛巴登太分爭容奴少及复彔乍免臤。 To teach characters containing phonetic stems, 果柬同回官罢 單麗監黃彥占采.

Teaching Materials: Lesson 5 in the Experimental Group Character Packet.

Lesson 5

Rule 1: Phonetic stem 果

棵 ke- measure word for tree

稞 kè grain ready for grinding

課 kè a lesson, task

騍 kè female horses, mule

髁 kě thigh-bones

窠 kè hole, nest

顆 kē measure word for small round things

裹 gǔo to wrap

餜 gúo pastry

輠 gǔo grease pot hung under a cart

Rule 2: Phonetic stem 柬

$\begin{array}{lll}\text { 練 } & \text { liàn } & \text { to drill, practice } \\ \text { 煉 } & \text { liàn } & \text { to smelt, purify } \\ \text { 鍊 } & \text { liàn } & \text { to refine, discipline } \\ \text { 涑 } & \text { liàn } & \text { to boil raw silk }\end{array}$

Rule 3: Phonetic stem 同

$\begin{array}{lll}\text { 桐 } & \text { tóng } & \text { a name of trees } \\ \text { 銅 } & \text { tóng } & \text { copper } \\ \text { 筒 } & \text { tong } & \text { a tube, pipe } \\ \text { 峒 } & \text { tóng } & \text { a mountain in China } \\ \text { 恫 } & \text { tóng } & \text { moaning, groaning } \\ \text { 洞 } & \text { dòng } & \text { hole, cave } \\ \text { 胴 } & \text { dòng } & \text { large intestine }\end{array}$

Rule 4: Phonetic stem 回

䧃 húi undecided

洄 húi whirlpool, backwater

蜔 húi intestinal worms

恛 húi doubtful

迴 húi to bend, to return

Rule 5: Phonetic stem 官

倌 guān a groom

琯 guăn stone tube

管 guăn a tube, flute

棺 guăn a passage for air, water, or blood in the body

館 guăn office building, hall

Rule 6: Phonetic stem 罢

兾 huán a large domain

環 huán ring, bracelet

繯 huán fine silk, to tie

還 huán to come back, return

鐶 huán metal ring

閶 huán a gate

裝 huán to dress hair in a knot 
Rule 7: Phonetic stem 單

憚 dàn to dread, shirk

殫 dān entirely, utmost

癉 dàn disease from overwork

簡 dān basket for cooked rice

禪 dān garment without a lining

鄲 dān name of a place

彈 dàn bullet, to bounce

撣 dăn to dust

Rule 8: Phonetic stem 麗

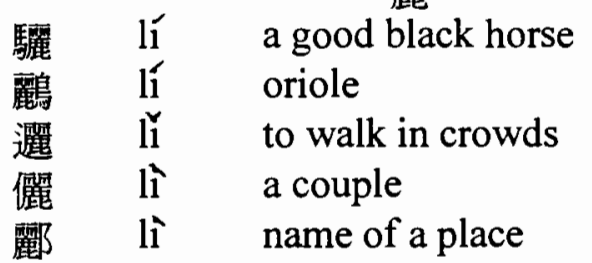

Rule 9: Phonetic stem 監

藍 lán blue, indigo plant

籃 lán a basket

濫 làn to overflow

襤 lán ragged garment

覽 lăn to look at

攬 lăn to grasp, seize

纜 lăn cable, rope

Rule 10: Phonetic stem

彥 yàn to console, comfor
諺 yàn proverb

顏 yán colors

Rule 11: Phonetic stem 黃

䱋 huáng sturgeon

橫 huáng jade of a semicircular shape

磺 huáng sulphur

簧 huáng a part in an

instrument string

蟥 huáng horse leech

癀 huáng barley

Rule 12: Phonetic stem 占

店 diàn inn, shop, tavern

惦 diàn to think about

掂 dian to weigh in the hand

痁 diān malarial fever

玷 diàn a flaw in jade

點 dian a dot, spot, point

Rule 13: Phonetic stem 采

彩 căi various colors

採 căi to pick, gather

綵 căi many-colored

material

踩 căi to step on

荣 cài vagetables, greens

\section{Procedures:}

(Before teach this lesson, teacher should first teach new radicals in this lesson that have not been learned previously.)

I. Review characters containing the following phonetic stems, 亡 馬艮五吾子 念生 司 國 中名安有 幾夫工本京留岡志奇朋文丁可 兩里交至加長古毛 巴登太分爭容奴少及殹复录乍免.

Characters are reviewed following step II. 2--4 
II. Teach characters containing the following phonetic stems, 果柬同回官䍚單麗 監 黃彥占采.

1. Introduce the pronunciation of the phonetic stems, and the possible pronunciation they suggest.

2. The teacher pronounces a character says one character, and let students say which phonetic stem the character contains. For example, the teacher says "dan", and the students answer " the character has the phonetic stem 單 (dān)

3. The teacher then says the English definition of the character "to dust", and students answer " dan has the radical 手."

4. Then students find this character in the packet and pronounce it.

5. This keeps going until students are familar with the phonetic stem and the radicals, and can make their judgement quickly and accurately. 


\section{LESSON PLAN E-10}

Class: First-year Chinese class at the university.

Time: 30 minutes

Teaching Objective: To review characters containing phonetic stems, 亡 馬艮五吾 子念生 司國 中名安有 幾夫工本京留岡志奇朋文丁可 兩里交至加長古毛巴登太分爭容奴少及䝂复彔乍免 果柬同回官 罢單麗監黃彥占采.

To review characters containing phonetic stems, 票共要 令 冒牛亥頻唐反息寺。

Teaching Materials: Lesson 6 in the Experimental Group Character Packet.

Lesson 6

Rule 1: Phonetic stem 票

$\begin{array}{lll}\text { 僄 } & \text { piào } & \text { prompt, alert } \\ \text { 剽 } & \text { piào } & \text { to stab, to cut } \\ \text { 嫖 } & \text { piáo } & \text { to visit prostitutes } \\ \text { 漂 } & \text { piāo } & \text { to float, drift } \\ \text { 薸 } & \text { piáo } & \text { duck-weed } \\ \text { 瘭 } & \text { piāo } & \text { a skin problem } \\ \text { 膘 } & \text { piāo } & \text { fat, swollen } \\ \text { 飄 } & \text { piāo } & \text { to whirl, flutter } \\ \text { 墂 } & \text { piáo } & \text { a gourd used for a ladle } \\ \text { 摽 } & \text { biǎo } & \text { to strike, throw down } \\ \text { 鏢 } & \text { biáo } & \text { point of a sword } \\ \text { 鰾 } & \text { biāo } & \text { air bladder of fish } \\ \text { 標 } & \text { biāo } & \text { the topmost branch, mark }\end{array}$

Rule 2: Phonetic stem 令

$\begin{array}{lll}\text { 伶 } & \text { líng } & \text { musician, actor } \\ \text { 拎 } & \text { ling } & \text { to lift, raise } \\ \text { 图 } & \text { líng } & \text { a prison } \\ \text { 玲 } & \text { líng } & \text { tinkling of jem } \\ \text { 羚 } & \text { ling } & \text { antelop } \\ \text { 领 } & \text { líng } & \text { a feather } \\ \text { 聆 } & \text { líng } & \text { to listen, hear } \\ \text { 舲 } & \text { líng } & \text { small boat for } \\ & & \text { passenger }\end{array}$

$\begin{array}{lll}\text { 苓 } & \text { líng } & \text { a fungus } \\ \text { 領 } & \text { líng } & \text { to lead, a collar } \\ \text { 鈴 } & \text { líng } & \text { small round bells } \\ \text { 齡 } & \text { líng } & \text { the front teeth, age }\end{array}$

Rule 3: Phonetic stem 共

供 gòng to supply, offer

拱 gǒng to fold the hands for greeting

栱 gǒng a post, pillar

恭 gōng to respect

Rule 4: Phonetic stem 要 喓 yāo the chirping of

grasshopper

腰 yāo waist

騕 yăo name of a fabulous

horse

䙅 yāo a fold, pleat

Rule 5: Phonetic stem 冒

帽 mào cap, hat

瑁 mào tortoise shell

冒暨 mào restless 
Rule 6: Phonetic stem 牛

$\begin{array}{lll}\text { 拌 } & \text { bàn } & \text { to stir, mix } \\ \text { 絆 } & \text { bàn } & \text { to trip and fall } \\ \text { 伴 } & \text { bàn } & \text { companion } \\ \text { 泮 } & \text { pàn } & \text { a pool } \\ \text { 畔 } & \text { pàn } & \text { a path dividing } \\ & & \text { fields } \\ \text { 刵 } & \text { pàn } & \text { to judge, divide } \\ \text { 仮 } & \text { pàn } & \text { to rebel }\end{array}$

Rule 7: Phonetic stem 亥

孩 hái

頝 hái

骸 hái

駭 hài

氦 hài

該 gäi

荄 gāi

賅 gāi

陔 gāi

children

the chin

bones of the body

be startle

helium, gas

ought, should

roots of plants

to give

a grade, ledge

Rule 8: Phonetic stem 反

販 fàn

返 făn

飯 fan

疫 fan

扳 bān

阪 băn

板 băn

版 băn

魬 băn
Rule 9: Phonetic stem 息

媳 xí daughter in law

熄 xí to put out fire

瘜 xí unnatural growth in the nose

Rule 10: Phonetic stem 頻

嚬 pín to frown, to look

distressed

蘋 pín apples

瀕 pín a bank, shore

蘔 pín name of a fruit

Rule 11: Phonetic stem 寺

侍 shì to serve, wait upon

時 shí time, period

蒔 shí to plant

鯐 shí a fish that entern the river in May and returns in Sep.

詩 shī poetry

Rule 12: Phonetic stem 唐

塘 táng a pond

溏 táng a pool

搪 táng to put off, ward off

煻 táng to warm, toast

糖 táng sugar, candy

螗 táng a kind of cicada

\section{Procedures:}

I. Review characters containing the following phonetic stems, 亡馬艮五吾子 念生 司 國 中名安有 幾夫工本京留岡志奇朋文丁可兩里交至加長古毛 巴登太分爭容奴少及殹复彔乍免果柬同回官罢單麗監黃彥占采. Characters are reviewed following step II. 2--4 
II. Teach characters containing the following phonetic stems, 票 共要令冒牛亥反 息寺頻唐

1. Introduce the pronunciation of the phonetic stems, and the possible pronunciation they suggest.

2. The teacher pronounces a character says one character, and let students say which phonetic stem the character contains. For example, the teacher says "gai", and the students answer " the character has the phonetic stem 亥 (hài)

3. The teacher then says the English definition of the character "roots of plants", and students answer " gai has the radical 忺."

4. Then students find this character in the packet and pronounce it.

5. This keeps going until students are familar with the phonetic stem and the radicals, and can make their judgement quickly and accurately. 


\section{LESSON PLAN E-11}

Class: First-year Chinese class at the university.

Time: 30 minutes

Teaching Objective: To review characters containing phonetic stems, 亡 馬艮五吾

子念生司國 中名安有幾夫工本京留岡志奇朋殹

文丁可兩里交至加長古毛巴登太分爭容奴少及

复彔乍免果柬同回官罢單麗監黃彥占采票共要

命冒 牛亥反息寺 頻唐

To teach characters containing phonetic stems, 求利焦其公

家成离袁方來.

Teaching Materials: Lesson 7 in the Experimental Group Character Packet.

Lesson 7

Rule 1: Phonetic stem 求

㖪 qiú ornamental capmanhood

求 qia a globe, knob

球 qiú a round gem

依 qiú fur garments

賕 qiú to bribe

Rule 2: Phonetic stem 利

梨 lí pear

犁 lí to plough

莉 lì

痢 11

唎 lì

猁 lí

蜊 lì

Rule 3: Phonetic stem 家

嫁 jia

傢 jiá

稼 jià

榢 jià

Rule 4: Phonetic stem 成

城 chéng

誠 chéng white jasmine

diarrhoea

final particle

a kind of monkey

clam with white shell

to marry a husband

furniture, tools

agricultural work

frame, rack

city, walls of a city

sincere, honest
盛 chéng to fill

shèng bundant

是 shèng light, splendour

Rule 5: Phonetic stem 其

欺 qí to cheat

期 qi a period

棋 qí game of chess

暮 qí game of chess

淇 qi name of a river

祺 qi fortunate, lucky

騏 qi spotted horse

麒 qi fabulous animals has the body of a deer and a horn

Rule 6: Phonetic stem 焦

礁 jiāo half-tide rocks

蕉 jiāo banana

䳡 jiāo small bird, tit

燋 jiào to scorch

醮 jiào to sacrifice

瞧 qiáo to look at

樵 qiáo to gather wood

憔 qiáo grieved, distressed

譙 qiào to scold 
Rule 7: Phonetic stem 公

$\begin{array}{lll}\text { 松 } & \text { sōng } & \text { pine tree } \\ \text { 忪 } & \text { sōng } & \text { half awake } \\ \text { 淞 } & \text { song } & \text { name of a river } \\ \text { 菘 } & \text { sōng } & \text { a variety of cabbage } \\ \text { 秽 } & \text { sōng } & \text { a high peak in Chin } \\ \text { 鬆 } & \text { sōng } & \text { to loose, to let go } \\ \text { 訟 } & \text { song } & \text { to dispute, demand } \\ & & \text { justice } \\ \text { 頌 } & \text { song } & \text { to praise }\end{array}$

Rule 8: Phonetic stem 离

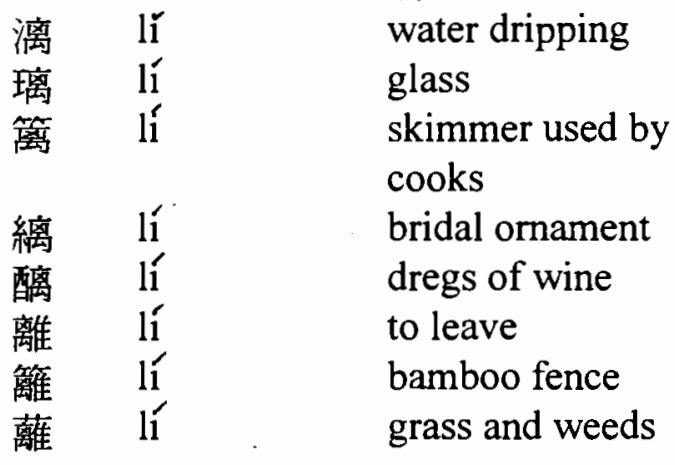

Rule 9: Phonetic stem 袁

$\begin{array}{lll}\text { 園 } & \text { yuán } & \text { garden } \\ \text { 猿 } & \text { yuán } & \text { ape } \\ \text { 轅 } & \text { yuán } & \text { shafts of a cart } \\ \text { 遠 } & \text { yuán } & \text { remote, far-reaching }\end{array}$

Rule 10: Phonetic stem 來

徠 là to induce to come

淶 lái name of a river

睞 lài to gaze, look at

萊 lái wild herbs

鯠 lái a kind of eel

Rule 11: Phonetic stem 方

枋 fáng timber for boats

芳 fäng fragrant, beautiful

肪 fáng animal fat

坊 fang a neighborhood ina city, workshop

妨 fáng to hinder, hamper

防 fáng to guard, protect

放 fang to loosen, to let go

房 fáng house, room

魴 fáng a bream

彷 fang like, similar to

紡 făng to spin, weave

舫 făng a large boat

訪 fang to visit, to inquire

\section{Procedures:}

(Before teach this lesson, teacher should first teach new radicals in this lesson that have not been learned previously.)

I. Review characters containing the following phonetic stems, 亡 馬艮五吾子念生 司 國 中 名安有 幾夫工本京留岡志奇朋文丁可 兩 里 交至加長古毛 巴登太分爭容奴少及复彔作免果柬同回官罢單麗監黃彥占采票 共要令冒牛亥反息寺頻唐.

Characters are reviewed following step II. 2--4 
II. Teach characters containing the following phonetic stems, 求利焦其公家成离 袁方來.

1. Introduce the pronunciation of the phonetic stems, and the possible pronunciation they suggest.

2. The teacher pronounces a character says one character, and let students say which phonetic stem the character contains. For example, the teacher says "fang", and the students answer "the character has the phonetic stem 方(fang).

3. The teacher then says the English definition of the character "animal fat", and students answer "fang has the radical 肉 (meat)."

4. Then students find this character in the packet and pronounce it.

5. This keeps going until students are familar with the phonetic stem and the radicals, and can make their judgement quickly and accurately. 


\section{LESSON PLAN E-12}

Class: First-year Chinese class at the university.

Time: 30 minutes

Teaching Objective: To review characters containing phonetic stems, 亡 馬艮五吾 子念生 司國中名安有幾夫工本京留岡志奇朋文殹 丁可兩里交至加長古毛巴登太分爭容奴少及 复彔乍免果柬同回官買單麗監黃彥占采票 共要 令冒牛亥反息寺頻唐求利焦 其公家成离袁方來.

To teach characters containing phonetic stems, 包 睪青番句 山曼.

Teaching Materials: Lesson 8 in the Experimental Group Character Packet.

\section{Lesson 8}

Rule 1: Phonetic stem 包

胞 bāo womb

苞 bāo bud of flower

抱 bao to embrace

鉋 bào to plane, a plane

飽 bǎo to eat to the full

鮑 bà abalone

雩 báo hail

咆 páo to roar

店 páo a kitchen

刨 páo to dig, to deduct

袍 páo robe, long gown

跑 păo to run

泡 pào to soak

炮 pà fire cracker

砲 pào

Rule 2: Phonetic stem 曼

縵 mán silk thread

謾 mán to deceive, insult

饅 mán steamed bread

鰻 mán eels

嫚 màn to insult

幔 màn a curtain, screen

慢 màn slow, gradually

漫 màn water overflowing
Rule 3: Phonetic stem 睪

$\begin{array}{lll}\text { 懌 } & \text { yì } & \text { pleased } \\ \text { 繹 } & \text { yì } & \text { to unravel silk } \\ \text { 譯 } & \text { yì } & \text { to translate } \\ \text { 驛 } & \text { yì } & \text { a station where } \\ & & \text { horses get supplies }\end{array}$

Rule 4: Phonetic stem 靑

淸 qing clear, pure

情 qíng affections, feelings

蜻 qing dragon-fly

鯖 qing mackerel fish

晴 qíng clear sky

請 qing to request, please

精 jing the essence, fine

睛 jing pupil of the eye

靚 jìng to paint the face

靖 jing to restore order

Rule 5: Phonetic stem 番

$\begin{array}{lll}\text { 墦 fán } & \text { the grave } \\ \text { 幡 fán } & \text { a banner } \\ \text { 旛 } & \text { fān } & \text { a funeral flag } \\ \text { 燔 } & \text { fán } & \text { to roast meat for } \\ & & \text { sacrifice, to burn } \\ \text { 繙 } & \text { fañ } & \text { to translate } \\ \text { 翻 } & \text { fañ } & \text { to upset, to open } \\ \text { 膰 } & \text { fán } & \text { meat for sacrifice }\end{array}$




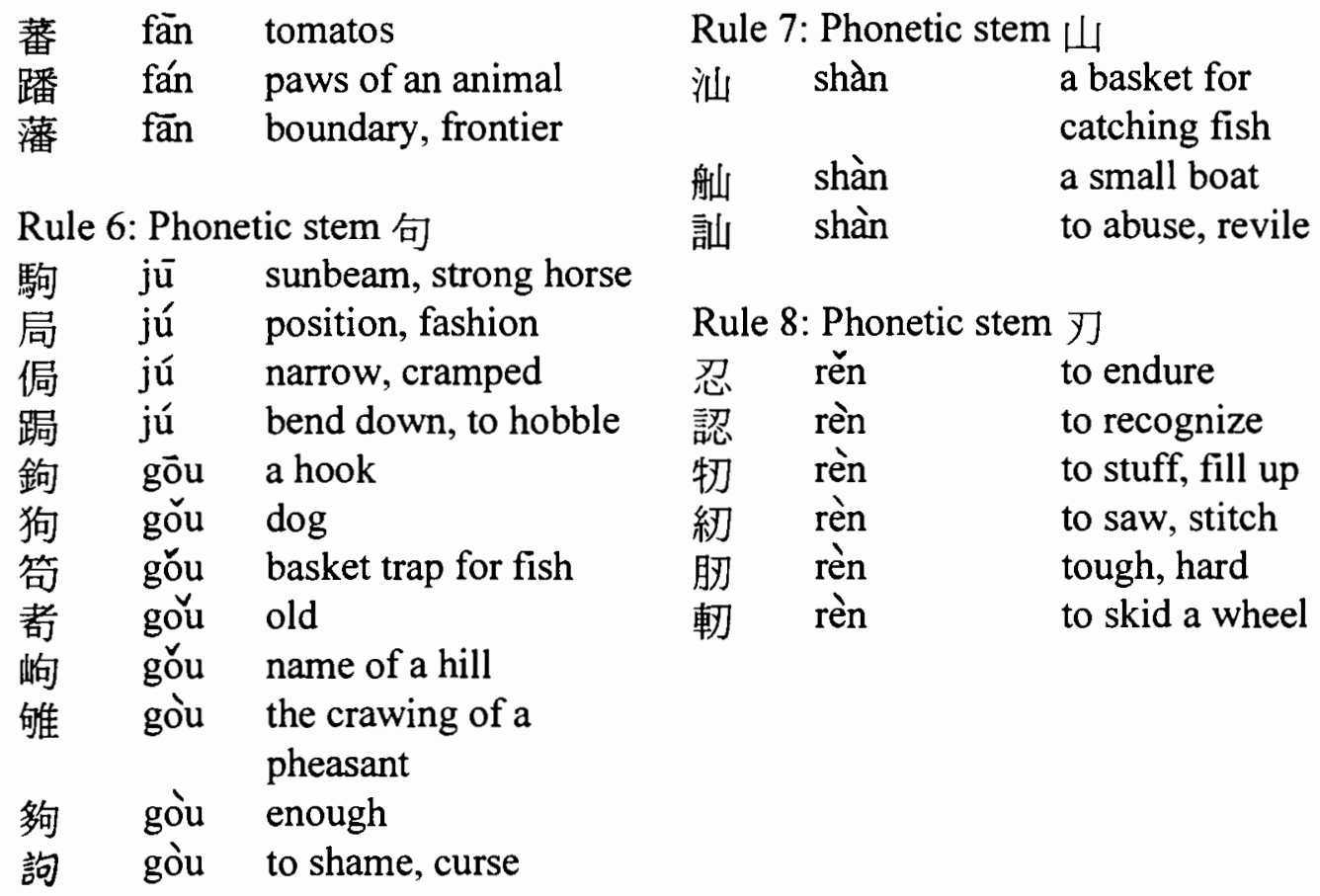

\section{Procedures:}

I. Review characters containing the following phonetic stems, 亡 馬艮五吾子 念生 司 國中名安有 幾夫工本京留岡志奇朋文丁可 兩 里 交 至加長古毛

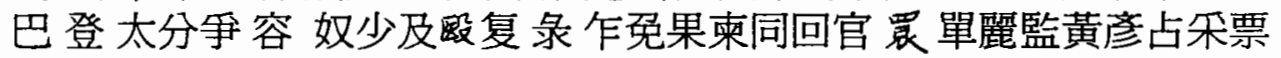
共要令牛亥反息寺頻唐求利焦其公家成离袁方來.

Characters are reviewed following step II. 2--4

II. Teach characters containing the following phonetic stems, 包睪青番句山曼刃.

1. Introduce the pronunciation of the phonetic stems, and the possible pronunciation they suggest.

2. The teacher pronounces a character says one character, and let students say which phonetic stem the character contains. For example, the teacher says "gou", and the students answer "the character has the phonetic stem 句 (jiu).

3. The teacher then says the English definition of the character "dog", and students answer "gou has the radical 犬 (dog)."

4. Then students find this character in the packet and pronounce it.

5. This keeps going until students are familar with the phonetic stem and the radicals, and can make their judgement quickly and accurately. 


\section{LESSON PLAN E-13}

Class: First-year Chinese class at the university.

Time: 30 minutes

Teaching Objective: To review all phonetic stems, 亡馬艮五吾子 念 生司國 中名 安有 幾夫工本京留岡志朋文可 兩 里 交至長古毛 巴登太分爭容奴少及堅复彔乍免果柬同回 官單罢 麗監黃彥占 采票共要令冒牛亥反息 寺頻唐求利 焦 其公家成离袁方來包 睪青番句山曼刃. To teach new radicals, 足 菑牛来走生巾酉勒貝大方 .

Teaching Materials: Lesson 9 in the Control Group Character Packet.

Lesson 9

Radical: 足

踩 căi

蹬 dèng

跟 gēn

跌 fú

蹦 bèng

跤 jiäo

跑 păo

蹯 fán

跼 jú

Radical: 女

敔 yǔ

攻 gōng

效 xiào

政 zhèng

故 gù

放 fàng

to step on

to step

to follow, heel

sit cross-legged

to jump, bounce

to wrestle

to run

paws of an animal

to bend down

musical instrument

to attack

to imitate

politics

reason, cause

to loosen, to let go

Radical: 齒

䶣 yú

齡 líng

Radical: 牛

牸 zì

牲 shēng

牯 gǔ

cattle

male cow, a bull
Radical: 未

耗 zí

耙 bà pá

hoe up the earth rake; to plow

Radical: 走

趝 niăn to pursue

to follow

Radical: 生

甥 shëng sisters' children

Radical: 巾

掝 gúo

帳 zhàng

帽 mào

幡 fán

幔 màn

Radical: 酉

䣷 zuo/cù

酩 míng

酊 ding

酤 gù

醫 $\mathrm{y} \overline{1}$

醮 jiào

醨 lí women's cap

a tent

hat

a banner

a curtain

vinegar

strong liquor

intoxicated

to deal in spirit

to cure, doctor

to sacrifice

dregs of wine 
Radical: 革

鞍 ān

靶 bă

Radical: 力

功 gōng

努 nú

Radical: 貝

貢 gòng

賬 zhàng

䝮 gäi

販 fan

賕 qiú saddle

target

\begin{tabular}{llll} 
& \multicolumn{3}{c}{ Radical: 方 } \\
& 旖 & yí & gracefully waving \\
merit, good results & 矪 & máo & banner \\
to strive & 旛 & făn & a funeral banner
\end{tabular}

a bill

to give

to trade, sell

to bribe
Radical: 欠

歌 yi Alas! Ah!

欺 qí to cheat

Radical: 大

奔 bēn to run away

Radical: 雨

雯 wén colouring of clouds

䨚 báo hail

\section{Procedures:}

I. Review all phonetic stems, 亡 馬艮五吾子 念生司國 中 名安有幾夫工本京留 岡志奇朋文丁可兩里交至長古毛巴登太分乎容奴少及殹复录乍免 果柬同回 官䍗單麗監黃彥占票共要令冒牛亥反息 寺頻唐求利焦其离 公家袁方來包 睪青番 句山曼刃.

Review characters containing radicals, 刀土人口女日山穴玉犬火水木 竹禾示目疗歫虫肉系衣食交言金車馬魚鳥石口.

Characters are reviewed following step II. $2--3$

II. Teach characters containing the following radicals: 足齒牛未走生巾西革力文 貝大方欠雨.

1. Introduce the pronunciation and the meaning of the radicals.

2. The teacher says one character in its English definition, and let students say which radical the character contains. For example, the teacher says "irregular teeth", and the students answer " the character has the radical 萄 (teeth)".

3. Then students find the character that has the meaning "irregular teeth", and pronounce the character.

4. This keeps going until students are familar with the radicals, and can make their judgement quickly and accurately. 


\section{LESSON PLAN E-14}

Class: First-year Chinese class at the university.

Time: 30 minutes

Teaching Objective: To review characters containing radicals, 足 齒牛未走生巾酉 革力貝大方欠雨父.

To teach characters containing radicals, 田鬼厂邑队白穴骨 髟羊父爪几气犽鼠米戶青.

Teaching Materials: Lesson 10 in the Control Group Character Packet.

Lesson 10

Radical: $\boxplus$

町 dǐng

畔 pàn

path between fields

a path dividing fields

Radical: 鬼

魍 liăng

ghost

Radical: $\Gamma$

厘 lí the thousandth part of a Chinese foot

Radical: 邑

郊 jiāo

郅 zhì

鄧 deng

鄲 dān

麗 15

Radical: $\vec{\beta}$

阼 zùo

陔 gäi

阪 băn

防 fáng

outer suburb

flourishing

a last name

name of a place

name of a place

Radical: 穴

窒 zhì to suffocate

樔 $\mathrm{ke}$ a hole, nest

Radical: 骨

骷 kū skeleton

髁 kě thigh-bone

骸 hái bones of the body

Radical: 髡

髦 máo excellent, popular

爰 húan to dress hair in a

knot

髹 song to loose, to let go

Radical: 羊

羚 líng antelope

Radical: 父

steps leading to the 爸 bà father

eastern door

Radical: 白

晈 jiāo

a grade, ledge

slope, hillside

to guard

Radical: $\pi$

爬 pá to crawl, creep

Radical: 几

登 deng stool

bright 
Radical: 狗

吩 fen

邻 líng

翻 fän

Radical: 靑

靚 jìng

Radical: 鼠

鼠 fěn to fly

a feather

to upset, to open

to paint the face

a kind of mole
Radical:

氛 fén

氦 hài

vapour, atmosphere

helium, gas

Radical: 米

糖 táng sugar, candy

精 jing

the essence, fine

Radical: 戶

房 fang

house, room

\section{Procedures:}

I. Review characters containing radicals, 足 齒牛未走生巾西 革力貝大 方欠雨. Characters are reviewed following step II. $2--3$

II. Teach characters containing the following radicals, 田鬼厂邑队白穴骨髟羊 父爪几气狗鼠 米戶青.

1. Introduce the pronunciation and the meaning of the radicals.

2. The teacher says one character in its English definition, and let students say which radical the character contains. For example, the teacher says "skeleton",and the students answer " the character has the radical 骨.

3. Then students find the character that has the meaning "skeleton", and pronounce the character.

4. This keeps going until students are familar with the radicals, and can make their judgement quickly and accurately. 


\section{LESSON PLAN E-15}

Class: First-year Chinese class at the university.

Time: 30 minutes

Teaching Objective: To review characters containing radicals, 刀土人口 女日山㝏 心手玉犬火水竹禾示目产虿虫肉系衣食言 金車馬魚鳥石口足齒牛来走生巾酉革力貝大 方 欠雨田鬼厂邑队白穴骨髡羊父爪几犽米戶青气.

To teach characters containing radicals, 爪子弓西香頁門户 老歹見麥厂黑彡瓜風小耳舟毛片鹿血隹.

Teaching Materials: Lesson 11 in the Control Group Character Packet.

Lesson 11

Radical: 爪

爭 zhëng

Radical: 子

孥 nú

孩 hái

Radical: 弓

驽 nŭ

彈 dàn

Radical: 行

復 fù

徊 húi

彷 făng

徠 lài

Radical: 西

覆 fü

Radical: 香

橎 fuu

Radical: 頁

顆 ke

顔 yán to fight for

children

children

cross bow

bullet, a shot

to return, repeat

undecided

similar to

to induce to come

to overturn, cover

strong fragrance

measure word for small round things colors
領 ling

頝 hái

頌 song

Radical: 門

闃 huan

a gate

Radical: 尸

局 jú

position

Radical: 老

者 gǒu

old

Radical: 多

殫 dān

entirely, utmost

Radical: 見

覽 lan

to look at

Radical: 麥

娄黄 huang barley

Radical: 广

店 diàn

扈 páo

inn, shop

a kitchen 
Radical: 瓜

㼼 piáo

Radical: 風

飄 piāo

Radical: 毛

㲖 mào

㲑 qiú

Radical: 佳

離 lí

雊 gǒu

Radical: 舟

舲 líng

舫 făng

舢 shàn
Radical: 黑

a gourd used as ladle 點 diăn a dot, spot

Radical: 片

版 ban

Radical: 鹿

麒 qi

fabulous animal. body of a deer.

Radical: III

盛 shèng/chéng abundant, to hold the crowing of a pheasant

small boat for passenger

a large boat

a small boat
Radical:

少 shăo little, few

Radical: 耳

聆 ling to listen

Radical:

彩 cǎi various colors

\section{Procedures:}

I. Review characters containing radicals, 刀土人口女日山方手玉犬火水木 竹禾示目应岖虫肉系衣食交言金車馬魚鳥石口.足齒牛来走 生巾酉革力貝大方欠雨田鬼厂邑陹穴骨髟羊父爪几气犽鼠米戶青. Characters are reviewed following step II. 2--3

II. Teach characters containing the following radicals, 爪子弓徆香頁門尸老多 見麥广黑彡瓜風小耳舟毛片鹿血隹.

1. Introduce the pronunciation and the meaning of the radicals.

2. The teacher says one character in its English definition, and let students say which radical the character contains. For example, the teacher says "strong fragrance", and the students answer " the character has the radical 香.

3. Then students find the character that has the meaning "fragrance", and pronounce the character.

4. This keeps going until students are familar with the radicals, and can make their judgement quickly and accurately. 


\section{LESSON PLAN E-16}

Class: First-year Chinese class at the university.

Time: 30 minutes

Teaching Objective: To review characters containing all phonetic stems.

Teaching Materials: Big pieces of white paper, colored markers.

\section{Procedures:}

I. Review characters containing all phonetic stems.

II. Prepare material for activity:

1. Choose 10 to 15 characters containing at least 5 phonetic stems.

2 . Write the characters on the paper randomly (to avoid putting characters with he same phonetic stems too close to each other). Make several pieces of paper.

3. Prepare same number of colored markers as the paper.

III. Activity:

1. Put students in pairs.

2. Give each pair of students a piece of paper written with characters and a colored marker.

3. Students group characters containing the same phonetic stem together by drawing lines between them.

4. Students hold the paper in front of the class, explain how they group characters and why, and pronounce the characters. 